DIEGO ANTONIO DE OLIVEIRA ROSA

GERENCIAMENTO DE RISCO APLICADO A PROCEDIMENTOS DE ENSAIOS DE EQUIPAMENTOS ELETROMÉDICOS 
DIEGO ANTONIO DE OLIVEIRA ROSA

\section{GERENCIAMENTO DE RISCO APLICADO A PROCEDIMENTOS DE ENSAIOS DE EQUIPAMENTOS ELETROMÉDICOS}

Dissertação apresentada à Escola

Politécnica da Universidade de São Paulo para a obtenção do título de Mestre em Ciências

Área de Concentração: Sistemas Eletrônicos, opção Engenharia Biomédica

Orientador: Prof. Dr. José Carlos Teixeira de Barros Moraes 
Este exemplar foi revisado e alterado em relação à versão original, sob responsabilidade única do autor e com a anuência de seu orientador.

São Paulo, de julho de 2012.

Assinatura do autor

Assinatura do orientador

FICHA CATALOGRÁFICA

Rosa, Diego Antonio de Oliveira

Gerenciamento de risco aplicado a procedimentos de ensaios de equipamentos eletromédicos / D.A.O. Rosa. -- ed.rev.

-- São Paulo, 2012.

$125 \mathrm{p}$.

Dissertação (Mestrado) - Escola Politécnica da Universidade de São Paulo. Departamento de Engenharia de Telecomunicações e Controle.

1. Bioengenharia 2. Administração de risco 3.Equipamentos eletromédicos I. Universidade de São Paulo. Escola Politécnica. Departamento de Engenharia de Telecomunicações e Controle II. t. 


\section{AGRADECIMENTOS}

Primeiramente gostaria de agradecer a Deus por todas as coisas maravilhosas proporcionadas. Aos meus mentores por me guiarem e me ensinarem a perceber o lado bom de tudo.

Agradeço ao meu pai, minha mãe e meus irmãos queridos Katia e Michel. Amo muito vocês.

Ao Prof. José Carlos Teixeira de Barros Moraes pela confiança, ensinamentos e toda a ajuda prestada durante esta longa caminhada.

Agradeço ao pessoal da DEC-LEB/EPUSP: Aline, Edison, Edilson, Fernando Rangel, Miguel, Sandro, Tiago e Vanessa.

Aos meus amigos, pelos ótimos momentos juntos, em especial a Diana, João, Murilo, Rodrigo Oliani e Tiago Fernandes. Obrigado pessoal. 


\section{RESUMO}

Os laboratórios de ensaios, para melhor avaliarem os equipamentos eletromédicos, precisarão implantar no seu sistema de gestão, o processo de Gerenciamento de Risco. Este novo tema está prescrito na edição da Norma ABNT NBR IEC 60601-1:2010 - Requisitos Gerais para Segurança Básica e Desempenho Essencial que entrará em vigor a partir de 2012 no Brasil. A presente pesquisa tem como objetivo apresentar resumidamente as etapas do processo utilizado para implantar o Gerenciamento de Risco nos procedimentos de ensaios de equipamentos eletromédicos, visando atender aos novos requisitos da série de Normas ABNT NBR IEC 60601/80601 objetivando a melhoria contínua do Sistema de Gestão de laboratórios de ensaios acreditados pelo INMETRO. O método utilizado para o desenvolvimento deste trabalho consistiu no estudo detalhado das duas edições brasileiras da Norma Geral, de Normas Colaterais, a da Norma Particular de bomba de infusão e controladores, bem como a Norma ABNT NBR ISO 14971:2009. Após o estudo destas Normas, foram analisados alguns arquivos de Gerenciamento de Risco fornecidos por fabricantes de equipamentos eletromédicos e realizado o estudo de algumas ferramentas utilizadas para o desenvolvimento do Gerenciamento de Risco como, por exemplo, FMEA, FTA e HAZOP. Também foram realizados treinamentos com a equipe do laboratório de ensaio para sua capacitação. Com esta série de atividades, foi possível o desenvolvimento e implantação dos necessários procedimentos de ensaios na DEC-LEB/EPUSP e a validação dos mesmos. Para a validação desses procedimentos foi utilizada uma bomba de infusão, juntamente com todos os seus documentos acompanhantes. $O$ resultado final obtido foi a capacitação da DEC-LEB/EPUSP para a realização de ensaios conforme as novas edições das Normas que incorporam Gerenciamento de Risco em suas prescrições, concluindo-se que os laboratórios de ensaios deverão incluir os devidos procedimentos com cuidado e capacitação de seus recursos humanos.

Palavras - Chave: Equipamento Eletromédico; Gerenciamento de Risco; Laboratório de Ensaio; Normas Técnicas. 


\begin{abstract}
To better evaluate the medical electrical equipment the laboratories for testing will need to deploy in its management system, the process of Risk Management. This new theme is prescribed in the edition of ABNT NBR IEC 60601-1:2010, which will take effect from 2012 in Brazil. This research aims to show brief the process used to implement the Risk Management procedures for testing medical electrical equipment, to meet the new requirements of the series of ABNT NBR IEC 60601/80601 aiming at continuous improvement of the management systems of laboratories for testing accredited by INMETRO. The method used for the development of this research was the detailed study of two Brazilian editions of the General Standard, Collateral Standards, Particular Standard of infusion pumps and controllers, as well as the ABNT NBR ISO 14971:2009. After studying these Standards, some Risk Management files provided by manufacturers of medical electrical equipment were analyzed and performed the study of some tools used for the development of Risk Management, for example, FMEA, FTA and HAZOP. Trainings were also conducted to the whole laboratory for testing team. With these activities, it was possible to develop and deploy the necessary testing procedures in DEC-LEB/EPUSP and validate procedures for testing. An infusion pump for the validation of these procedures was used, along with all its accompanying documents. The final result was the training of DEC-LEB/EPUSP team for testing as new editions of the standards that incorporate Risk Management in their prescriptions, concluding that laboratories for testing must include appropriate procedures and training of their human resources.
\end{abstract}

Key words: Medical Electrical Equipment; Risk Management; Laboratory for Testing; Technical Standards. 


\section{LISTA DE ILUSTRAÇÕES}

Figura 2.1- Processo de GeREnciamento de Risco de Acordo com a AS/NZS

4360:2004

Figura 2.2- Processo de GeRenciamento de Risco SEGUNdo

PRAM

Figura 2.3- Processo de Gerenciamento de Risco segundo o Guia

M_O_R.

Figura 2.4- Processo de GeREnCiamento de Risco SEgundo GuiA

PMBOK

Figura 2.5- Processo de Gerenciamento de Risco segundo a ABNT NBR IEC

14971:2099

FIGURA 2.6: REPRESENTAÇÃO GRÁFICA DA RELAÇÃO ENTRE PERIGO, SITUAÇÃO PERIGOSA E

DANO NA DETERMINAÇÃO DE RISCO......................................................46

FIGURA 2.7- EXEMPLO DE FORMULÁRIO DE FMA .............................................. 54

FIGURA 2.8-PROCEDIMENTO PARA A ESTRUTURA DE UMA ÁRVORE DE FALHA..................57

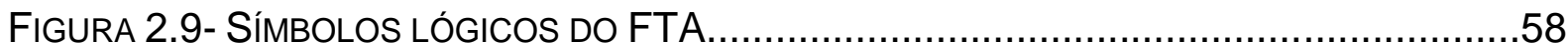

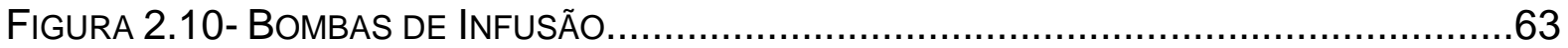

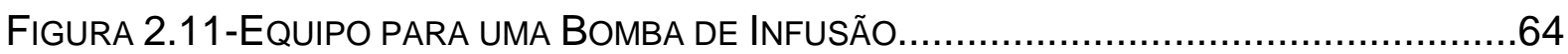

FiguRA 2.12- ARRANJO PARA ENSAIOS DE BOMBAS DE INFUSÃO E CONTROLADORES........65

FIGURA 2.13- ARRANJO PARA ENSAIO DE BOMBA DE SERINGA..................................65

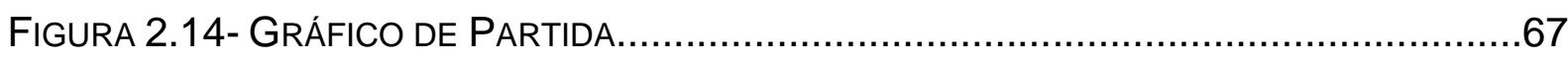

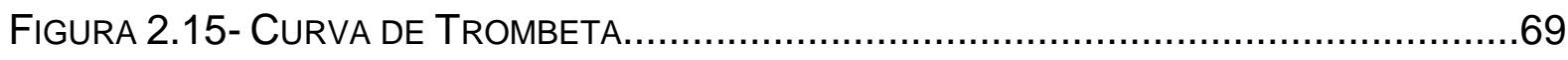

FIGURA 4.1- NúMERO DE FABRICANTES SE ADEQUANDO A NOVA EDIÇÃO DA NORMA

GeRAL

FIGURA 4.2- NÚMERO DE PESSOAS NAS EMPRESAS ENVOLVIDAS COM O PROCESSO DE

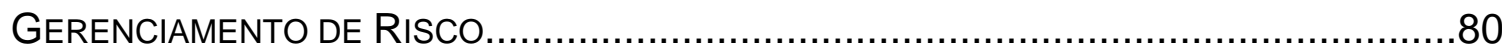

FIGURA 4.3- FERRAMENTAS UTILIZADAS NA ANÁLISE DE RISCO................................80

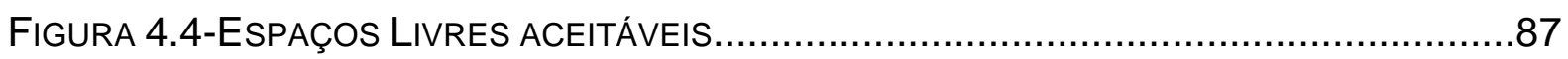

FIGURA 4.5 - ROLETE E TAMPA DE PROTEÇÃO DO SISTEMA MECÂNICO DE

INFUSÃO.

FIGURA 4.6 - DOCUMENTAÇÃO DE REQUISITOS PARA SISTEMA ELETROMÉDICO

ProgramÁvel 
FIGURA 4.7- GRÁFICO DE PARTIDA 1ML/H, 2 HORAS DE ENSAIO.

FIGURA 4.8- GRÁFICO dE PARTIDA 25ML/H, 2 HORAS DE ENSAIO SEM PRESSÃO

ADICIONAL

Figura 4.9-CuRVA de TROMBETA, $2^{A}$ HORA DE ENSAIO, $1 \mathrm{ML} / \mathrm{H}$. 112

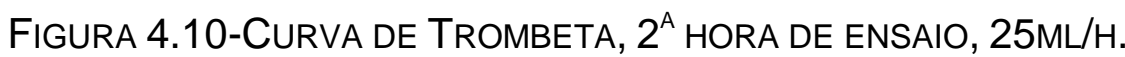
112 


\section{LISTA DE TABELAS}

TABELA 2.1 - LABORATÓRIOS BRASILEIROS DE ENSAIOS EM EQUIPAMENTO ELETROMÉDICO

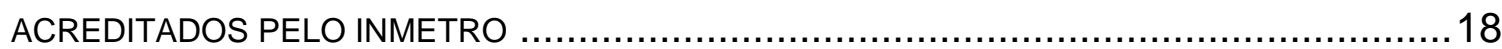

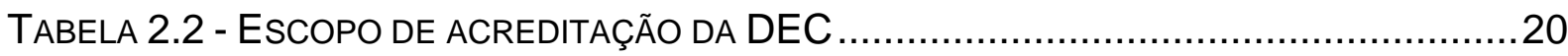

TABELA 2.3 - NORMAS PUBLICADAS PELA ABNT DA SÉRIE 60601 ....................24

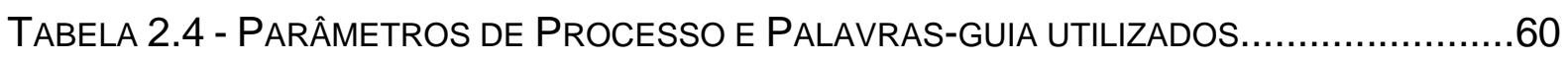

TABELA 2.5 - VAZÕES ESTABELECIDAS E VOLUMES DE BOLUS ...................................6

TABELA 2.6 - BOMBAS DE INFUSÃO ENSAIADAS NA DEC-LEB/EPUSP NOS ÚLTIMOS CINCO

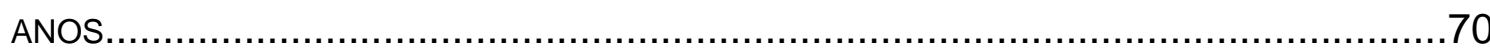

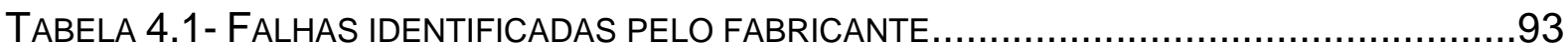




\section{SUMÁRIO}

1 INTRODUÇÃO

1.1 APRESENTAÇÃO

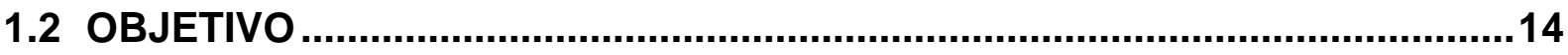

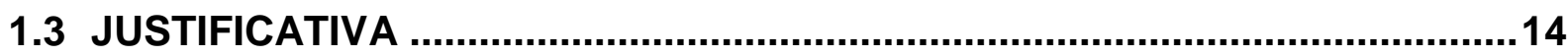

2 SISTEMA BRASILEIRO DE CERTIFICAÇÃO DE EQUIPAMENTOS ELETROMÉDICOS

\subsection{O PROCESSO DE REGISTRO E CERTIFICAÇÃO DE EQUIPAMENTOS} ELETROMÉDICOS E SEU OBJETIVO NO ÂMBITO NACIONAL

\subsection{LABORATÓRIOS BRASILEIROS DE ENSAIOS EM EQUIPAMENTOS} ELETROMÉDICOS ACREDITADOS PELO INMETRO

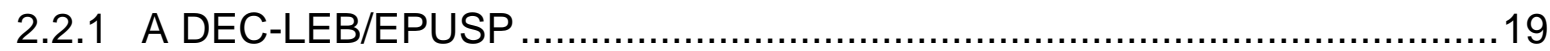

2.3 A SÉRIE DE NORMAS TÉCNICAS ABNT NBR IEC 60601/80601 .................23

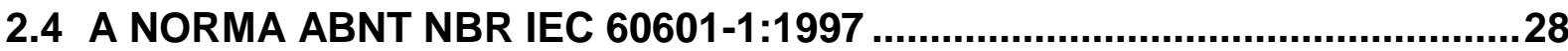

2.5 A NORMA ABNT NBR IEC 60601-1:2010

2.5.1 Requisitos Gerais do processo de Gerenciamento de Risco para Equipamentos Eletromédicos ou Sistemas Eletromédicos conforme a Norma ABNT NBR IEC 60601-1:2010 ............................................................34

2.5.2 Requisitos Gerais para ensaios em Equipamentos Eletromédicos ..............35

2.5.3 Requisitos para Equipamentos com um Subsistema Eletrônico

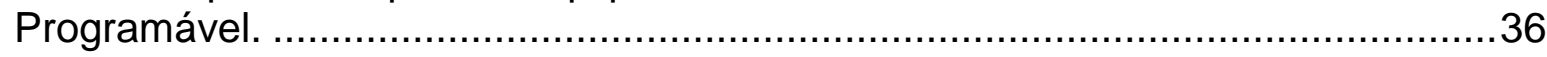

2.6 GERENCIAMENTO DE RISCO E A NORMA ABNT NBR ISO 14971:2009......36

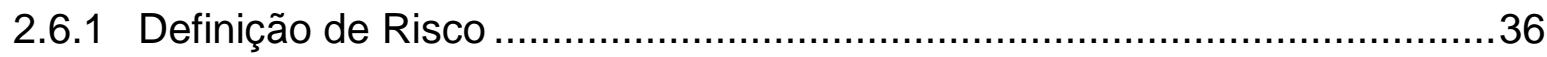

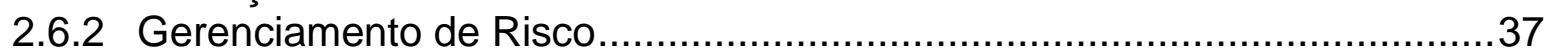

2.6.3 Quando deve e quando não deve ser aplicado o Gerenciamento de Risco 42

2.6.4 Gerenciamento de Risco de acordo com a Norma ABNT NBR ISO

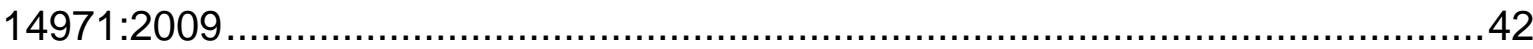

2.6.5 O objetivo do Gerenciamento de Risco aplicado a Equipamentos Eletromédicos....................................................................................44 2.6.6 Conceitos Básicos de Gerenciamento de Risco conforme a Norma ANBT

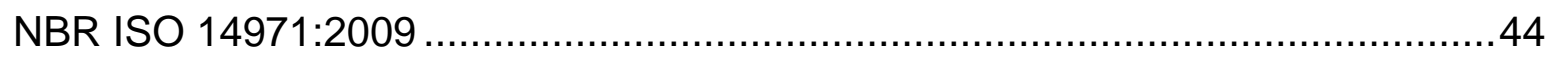

2.6.7 Estrutura e Requisitos da Norma ABNT NBR ISO 14971:2009 _...............47

2.6.8 Análise do Tipo e Efeito de Falha - FMEA …....................................52

2.6.8.1 Processo de Aplicação .................................................................53

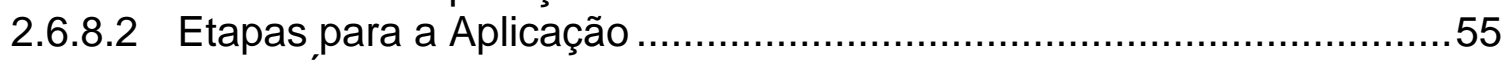

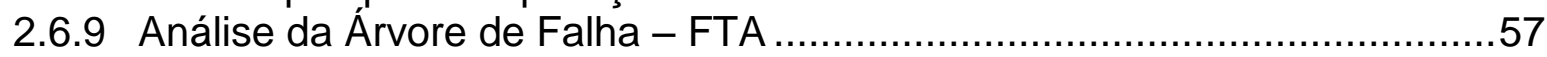

2.6.10 Estudo de Perigo e Operabilidade - HAZOP .......................................58

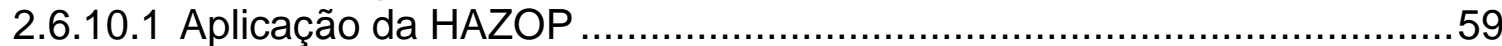

2.6.11 Comparação entre as Metodologias FMEA, FTA e HAZOP. .....................61 
2.8 A NORMA IEC 60601-2-24

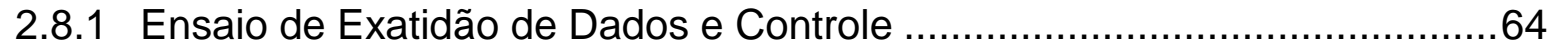

2.8.2 Ensaios de Bombas de Infusão na DEC-LEB/EPUSP …..........................70

3 MATERIAIS E MÉTODOS PARA A EXECUÇÃO DA PESQUISA ...................71

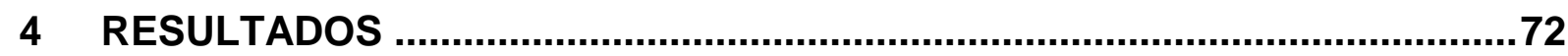

4.1 AS MUDANÇAS ENTRE AS DUAS EDIÇÕES DA NORMA GERAL ...............73

4.2 AS MUDANÇAS ENTRE AS DUAS EDIÇÕES DA NORMA 60601-2-24 .........74

4.3 ESTUDO DO GERENCIAMENTO DE RISCO ELABORADO POR EMPRESAS DE EQUIPAMENTOS ELETROMÉDICOS .....................................................75

4.4 ANÁLISE DA PESQUISA FEITA COM OS FABRICANTES DE EQUIPAMENTOS ELETROMÉDICOS ….........................................................78

4.5 ELABORAÇÃO E ATUALIZAÇÃO DE PROCEDIMENTOS DE ENSAIOS NA

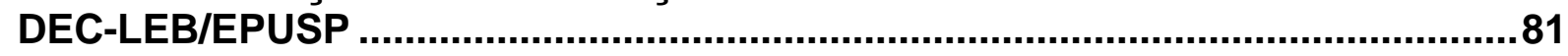

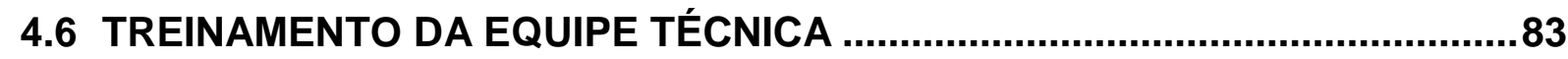

4.7 PROCESSO DE VALIDAÇÃO DOS PROCEDIMENTOS DE ENSAIOS NA

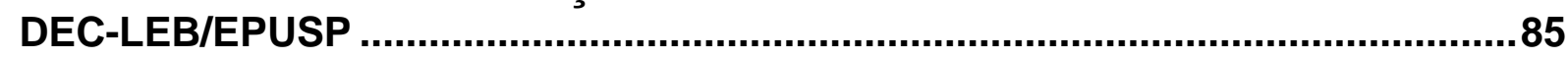

4.8 PROCEDIMENTOS DE ENSAIOS DA NORMA 60601-1:2010.......................86

4.8.1 Ensaios da Seção 9 da Norma Geral (Ensaios Mecânicos)........................86

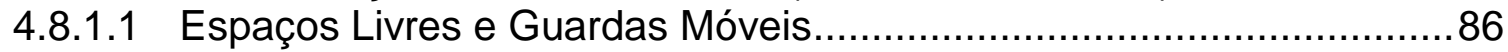

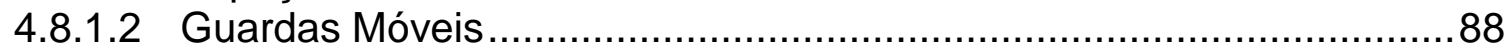

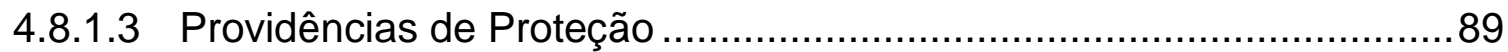

4.8.1.4 Perigos de Partes Expelidas ........................................................90

4.8.1.5 Energia Acústica incluindo infrassom e ultrassom ...........................90

4.8.2 Ensaios de Exatidão de Controles, Instrumentos e Proteção contra Saída

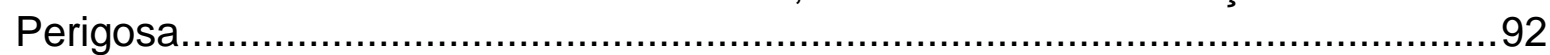

4.8.2.1 Exatidão de Controle e Instrumento.................................................92

4.8.2.2 Usabilidade .................................................................................93

4.8.2.3 Sistemas de Alarme .............................................................94

4.8.2.4 Indicação de Parâmetros pertinentes à segurança ...............................96

4.8.2.5 Seleção acidental de valores excessivos de saída .............................96

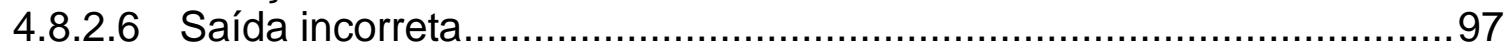

4.8.3 Sistemas Eletromédicos Programáveis................................................98

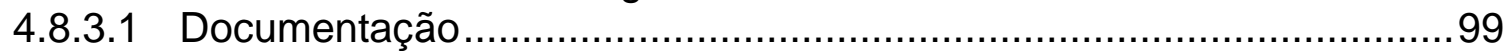

4.8.3.2 Plano de Gerenciamento de Risco ..............................................100

4.8.3.3 Processo de Gerenciamento de Risco (Identificação de Perigos) .....101

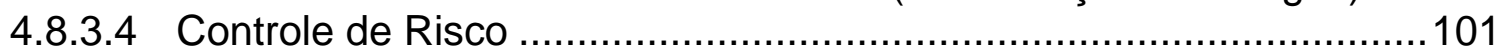

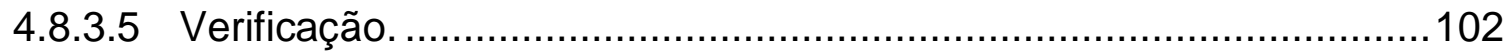

4.8.3.6 Validação do Sistema Eletromédico Programável. ............................103 
4.9 ENSAIOS DA NORMA COLATERAL IEC 60601-1-6:2006........................103

4.9.1 Segurança para o paciente, operador e outras pessoas..........................104

4.9.2 Especificação de aplicação do equipamento ........................................ 105

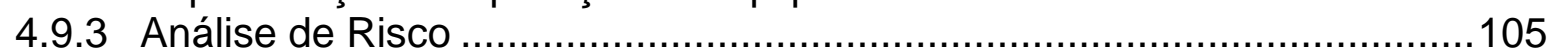

4.9.4 Especificação de Usabilidade ....................................................... 106

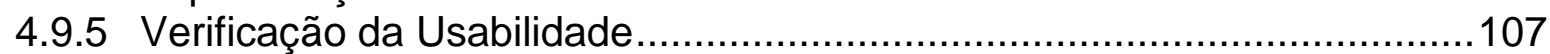

4.9.6 Plano de Validação de Usabilidade.................................................. 108

4.10 ENSAIO DE EXATIDÃO DE DADOS DA NORMA IEC 60601-2-24...........109

4.11 RESULTADO ESPERADO APÓS A AUDITORIA DO INMETRO ................113

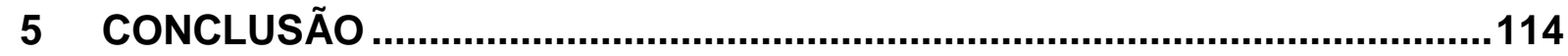

5.1 CONCLUSÃO SOBRE A NORMA ABNT NBR IEC 60601-1:2010 E ABNT NBR ISO 14971:2009 .............................................................................................114

5.2 CONCLUSÃO SOBRE A NORMA IEC 60601-2-24 .................................115

5.3 CONCLUSÃO APÓS A PESQUISA FEITA COM OS FABRICANTES DE EQUIPAMENTOS ELETROMÉDICOS ..................................................................116

5.4 CONCLUSÃO FINAL..............................................................................117

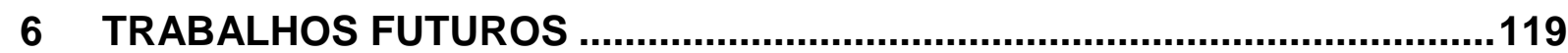

REFERÊNCIAS BIBLIOGRÁFICAS............................................................120 


\section{INTRODUÇÃO}

\subsection{APRESENTAÇÃO}

O avanço da tecnologia permitiu dar um enorme passo no desenvolvimento de produtos cada vez mais sofisticados na área da saúde. Uma classe de produtos que passou por um processo de aperfeiçoamento muito grande nos últimos anos, e ainda continua evoluindo intensamente, corresponde aos equipamentos eletromédicos.

Equipamento eletromédico segundo a Norma da ABNT NBR IEC 60601-1: 2010 (Associação Brasileira de Normas Técnicas/ International Electrotechnical Commission ${ }^{[1]}$ é um equipamento elétrico que possui parte aplicada ou que transfere energia do ou para o paciente ou detecta tal transferência de energia de ou para o paciente e que é fornecido com não mais que uma conexão a uma rede de alimentação elétrica; é destinado por seu fabricante para ser utilizado no diagnóstico, tratamento ou monitorização de um paciente ou na compensação ou alívio de doença, ferimento ou invalidez. Parte aplicada é a parte de um equipamento eletromédico que, em utilização normal, necessariamente entra em contato físico com o paciente para que o equipamento eletromédico ou sistema eletromédico realize sua função.

Já segundo a Portaria 350 do Instituto Nacional de Metrologia Normalização e Qualidade Industrial (Inmetro) ${ }^{[2]}$, os equipamentos eletromédicos, inclusive suas partes e acessórios, são os energizados por meio da rede de alimentação elétrica ou fonte de alimentação interna com finalidade médica, odontológica, laboratorial ou fisioterápica, utilizados direta ou indiretamente para diagnóstico, tratamento e monitorização em seres humanos, incluindo ainda aqueles com finalidade de embelezamento e estética.

Para produtos que mantém uma interação grande com seres humanos é de fundamental importância manter a segurança e a funcionalidade dos mesmos, pois garantindo a qualidade e a segurança desses equipamentos a chance de algum 
dano ser causado ao paciente e/ou ao operador pode ser diminuída consideravelmente.

No Brasil, os equipamentos eletromédicos precisam ser registrados na Agência Nacional de Vigilância Sanitária (Anvisa) para que possam ser comercializados. Para obter o registro, segundo a Resolução de Diretoria Colegiada (RDC) 27 de Junho de $2011^{[3]}$, é necessário que o equipamento obtenha o certificado de conformidade que atesta que o produto atende prescrições de segurança e desempenho essencial, processo que é conduzido por um Organismo de Certificação de Produto (OCP) e tem a participação de laboratórios de ensaios, ambos devidamente acreditados pelo Inmetro. As principais atividades dos OCPs são realizar tanto a avaliação da garantia da qualidade de fábrica como a verificação dos ensaios de rotina, esclarecendo ainda ao solicitante todas as exigências do processo de certificação e indicando laboratórios capacitados para que os ensaios sejam executados. O papel dos laboratórios de Ensaios é realizar ensaios de segurança e desempenho essencial de acordo com a série de Normas Técnicas ABNT NBR IEC 60601/80601.

As Normas Técnicas da Série ABNT NBR IEC 60601/80601 são utilizadas em todo o processo de certificação de equipamentos eletromédicos. Quando mencionada a série, entenda-se que para a realização dos ensaios serão adotadas a Norma Técnica Geral ABNT NBR IEC 60601-1, Normas Colaterais ABNT NBR IEC 60601-1-xx e Normas Particulares ABNT NBR IEC 60601-2-xx. A Norma ABNT NBR IEC 60601-1: Prescrições Gerais para Segurança de Equipamentos Eletromédicos, ou Norma Geral como é chamada, especifica requisitos gerais para a avaliação da segurança e desempenho essencial de todos os equipamentos eletromédicos ${ }^{[4]}$. Todo o texto da Norma Geral serve como base para as prescrições de Normas Particulares que são específicas a um dado tipo de equipamento eletromédico. Estas Normas Particulares complementam ou, em alguns casos, alteram alguns itens da Norma Geral ${ }^{[1]}$. Muitas vezes esta série de Normas faz referências a outras, como por exemplo, as conhecidas Normas International Organization for Standardization (ISO). Por exemplo, um equipamento de anestesia, além de ser ensaiado pela Norma Geral, pelas Normas Colaterais e pela sua Norma Particular ABNT NBR IEC 60601-2-13, também é ensaiado por nove diferentes Normas ISO.

Com a complexidade dos novos equipamentos eletromédicos, devido às suas inúmeras funções e aplicabilidades, os organismos responsáveis pela elaboração de 
Normas Técnicas observaram a necessidade do aprimoramento das exigências relativas a risco e métodos de ensaio. Na nova edição da Norma Geral há algumas mudanças essenciais, como por exemplo, novos ensaios e o conceito de desempenho essencial. Outro novo tema a ser trabalhado pelos laboratórios na realização de ensaios prescritos por essa Norma é o Gerenciamento de Risco. Esta nova exigência tem como objetivo fazer uma avaliação mais aprofundada das possíveis falhas em equipamentos eletromédicos e minimizá-las, pois o Gerenciamento de Risco exige dos fabricantes uma visão global desde a fase de projeto do produto até seu descarte, permitindo não somente que sejam identificados pontos críticos e possíveis melhorias, mas também considerando todo o ciclo de vida do produto. Como a edição da Norma ABNT NBR IEC 60601-1 publicada em 2010 passará a vigorar em 2012, o Sistema Brasileiro de Certificação exigirá em curto prazo um processo completo de avaliação de Gerenciamento de Risco. Também há exigências da Norma ABNT NBR ISO 14971:2009 a serem consideradas, ou seja, os laboratórios serão obrigados a se adaptarem para verificar novos requisitos estabelecidos por essas duas Normas Técnicas. Observa-se que as Normas Colaterais e Particulares também apresentam nas suas prescrições vários itens de Gerenciamento de Risco.

A Divisão de Ensaios e Calibração do Laboratório de Engenharia Biomédica da Escola Politécnica da Universidade de São Paulo (DEC-LEB/EPUSP) é um laboratório de ensaios acreditado pelo Inmetro que preza pela sua melhoria contínua e busca constantemente aprimorar seu Sistema de Gestão por meio de experiências com auditorias e por ações planejadas internamente pela alta direção. Por isso, também está em processo de adaptação à nova edição da série de Normas ABNT NBR IEC 60601/80601. Consequentemente, uma das atividades necessárias é a adequação do laboratório às novas diretrizes que envolvem Gerenciamento de Risco. 


\subsection{OBJETIVO}

O objetivo inicial do trabalho foi estudar e adquirir conhecimentos das prescrições da Norma ABNT NBR IEC 60601-1:2010 e fazer uma comparação com a edição de 1997 da Norma Geral atualmente em vigor no Brasil, após realizar um estudo sobre Gerenciamento de Risco e a Norma ABNT NBR ISO 14971:2009.

Posteriormente, elaborar e/ou atualizar métodos e processos de ensaios de equipamentos eletromédicos utilizados pela DEC-LEB/EPUSP, adaptando-os às novas diretrizes que envolvem Gerenciamento de Risco, obviamente atendendo aos critérios e exigências da Norma ABNT NBR ISO/17025:2005 - Requisitos Gerais para a Competência de laboratórios de ensaio e Calibração ${ }^{[5]}$. A subcláusula 5.4.1 dessa Norma estabelece que o laboratório de ensaio deve utilizar métodos e procedimentos apropriados para todos os ensaios e/ou calibrações dentro do seu escopo. Todas as instruções, Normas, manuais e dados aplicáveis ao trabalho do laboratório devem ser mantidos atualizados e prontamente disponíveis para o pessoal.

Após a elaboração dos procedimentos necessários, a pesquisa inclui ensaios em uma bomba de infusão, juntamente com toda a sua documentação (manual de ensaio e arquivo de Gerenciamento de Risco), para validar os procedimentos desenvolvidos.

O objetivo geral esperado é realizar a complementação e a capacitação da DEC-LEB/EPUSP, tanto em relação à infraestrutura e documentação como em recursos humanos, para realizar ensaios de equipamentos eletromédicos de acordo com a nova série de Normas ABNT NBR IEC 60601/80601 que inclui Gerenciamento de Risco em suas prescrições.

\subsection{JUSTIFICATIVA}

Os laboratórios de ensaios de equipamento eletromédico no Brasil atualmente realizam os ensaios segundo a série de Normas ABNT NBR IEC 60601/80601 que 
se baseia na edição da Norma Geral ABNT NBR IEC 60601-1:1997. Porém, os laboratórios precisarão adequar seus procedimentos para a nova edição ABNT NBR IEC 601601-1:2010 e, em uma segunda etapa, às demais novas edições das Normas da série. O conteúdo destas Normas irá alterar profundamente o processo de certificação de equipamentos eletromédicos, pois sua nova estrutura e fundamentos seguem a abordagem de análise de Gerenciamento de Risco desde o projeto do produto e durante todo o seu ciclo de vida.

Em decorrência de todos os critérios abordados, principalmente sobre Gerenciamento de Risco, a justificativa principal deste trabalho é contribuir para que a DEC-LEB/EPUSP possua capacitação técnica e infra-estrutura para atender aos novos requisitos das Normas da série 60601, ou seja, contribuir para a melhoria do seu Sistema de Gestão e de seus Manuais de Ensaios. Para isto, será imprescindível avaliar e atualizar os procedimentos de ensaios atuais e, quando necessário, implantar novos procedimentos. Além disso, se necessário, efetuar a compra de instrumentos de medição e montagens de arranjos de ensaio, bem como organizar toda a documentação para o processo de acreditação da DECLEB/EPUSP junto ao Inmetro.

A bomba de infusão foi escolhida para ser utilizada no processo de validação devido à grande demanda de ensaios deste tipo de equipamento na DECLEB/EPUSP. Para as outras Normas Particulares presentes no escopo do laboratório, serão desenvolvidos novos procedimentos futuramente.

Finalmente também é importante enfatizar que os laboratórios de ensaios possuem papel importante na manutenção e melhoria da infraestrutura tecnológica do país, contribuindo decisivamente para a qualidade dos produtos médicos comercializados. 


\section{SISTEMA BRASILEIRO DE CERTIFICAÇÃO DE EQUIPAMENTOS ELETROMÉDICOS}

\subsection{O PROCESSO DE REGISTRO E CERTIFICAÇÃO DE EQUIPAMENTOS ELETROMÉDICOS E SEU OBJETIVO NO ÂMBITO NACIONAL}

Para um equipamento eletromédico ser comercializado no Brasil é necessário que o mesmo seja registrado na Anvisa, a agência reguladora vinculada ao Ministério da Saúde e que exerce o controle sanitário de todos os produtos e serviços no Brasil. De acordo com RDC 27 de 2011 da ANVISA, os equipamentos eletromédicos só podem ser registrados se os produtos forem certificados. Para que um equipamento eletromédico seja certificado, este precisa atender aos requisitos de um determinado conjunto de Normas Técnicas da série ABNT NBR IEC $60601 / 80601^{[3]}{ }^{[4]}$. O processo de certificação é regulamentado pelo Inmetro através da Portaria 350 de $2010^{[2]}$.

Para dar início ao processo de certificação do seu produto, um determinado fabricante deve procurar um OCP que é uma instituição acreditada pelo Inmetro. As responsabilidades do OCP incluem, principalmente, tanto analisar toda a documentação do produto e auxiliar o fabricante na determinação de quais Normas Técnicas são aplicáveis para solicitar os ensaios, como avaliar o Sistema de Gestão e o processo de produção da fábrica. Estas atividades são realizadas incluindo uma auditoria e um acompanhamento de ensaios de verificação em amostras tomadas no comércio e na fábrica. Além da auditoria, avaliação e aprovação do processo de produção, O OCP seleciona uma amostra do produto para ser enviada a um laboratório de ensaios, que também é uma entidade acreditada pelo Inmetro.

O papel dos laboratórios de ensaio é realizar os ensaios prescritos na série de Normas Técnicas ABNT NBR IEC 60601/80601, registrar os resultados e fornecer um relatório ao OCP com os resultados obtidos. O OCP analisará o relatório e determinará se o equipamento eletromédico está ou não conforme as Normas de referência. Se, após a avaliação na fábrica, o processo de produção mostrar que 
segue as regras da Portaria 350 do Inmetro e se o produto atender todas as prescrições das Normas Técnicas de referência, o OCP poderá emitir o Certificado de Conformidade do Produto. Para concluir o processo de registro na Anvisa, o fabricante deve apresentar este Certificado juntamente com os demais documentos exigidos por essa Agência para obter a autorização (registro) para comercializar o produto por cinco anos ${ }^{[3]}$.

O tempo necessário para obter o certificado e o registro depende do grau de complexidade do equipamento, pois cada produto estará sujeito a uma ou mais determinadas Normas, à velocidade de avaliação do OCP e ao tempo e disponibilidade para a realização dos ensaios junto aos laboratórios. Também é importante destacar outro fator que poderá atrasar o processo, que é a possibilidade de o equipamento ser reprovado em alguns ensaios e o fabricante necessitar fazer as correções para depois reenviar aos laboratórios para nova avaliação de conformidade.

\subsection{LABORATÓRIOS BRASILEIROS DE ENSAIOS EM EQUIPAMENTOS ELETROMÉDICOS ACREDITADOS PELO INMETRO}

A RBLE (Rede Brasileira de laboratórios de ensaios) é um conjunto de laboratórios acreditados pelo Inmetro considerados como aptos a realizar serviços de ensaio.

Os laboratórios de ensaios em equipamentos eletromédicos acreditados pelo Inmetro são entidades que pertencem à RBLE e podem realizar as seguintes atividades:

- Ensaios para Certificação: Um OCP contrata o laboratório para a realização de ensaios para a certificação de um produto. A certificação é realizada pela OCP e não pelo laboratório que realizou os ensaios, pois este apenas apresenta um relatório de ensaios sem fornecer interpretação de conformidades, tipicamente. 
- Ensaios para Adequação: Uma empresa fabricante contrata o laboratório diretamente, sem a participação de um OCP para verificar o desempenho do seu produto antes de iniciar o processo de certificação.

Atualmente existem doze laboratórios acreditados pelo Inmetro para ensaiar equipamentos eletromédicos no Brasil, apresentados na Tabela 2.1.

Tabela 2.1 - Laboratórios Brasileiros de Ensaios em Equipamentos Eletromédicos acreditados pelo Inmetro (fonte: Sítio Inmetro 09/Jan/2012).

Instituto de Pesquisas Tecnológicas da Universidade de São Paulo - (IPT-USP) - CRL 0045.

Instituto de Eletrotécnica e Energia da Universidade de São Paulo (IEE - USP) - CRL 0062.

Pontifícia Universidade Católica do Rio Grande do Sul - PUC/RS - Laboratórios especializados em Eletro-Eletrônica - LABELO da PUC-RS - CRL 0075.

CIENTEC - Fundação de Ciência e Tecnologia - Departamento de Engenharia Eletroeletrônica - CRL 0083

TUV Rheiland do Brasil LTDA - UCIEE - CRL 0142

IBEC - Instituto Brasileiro de Ensaios de Conformidade Ltda - CRL 0143

Divisão de Ensaios e Calibração - Laboratório de Engenharia Biomédica - Escola Politécnica da Universidade de São Paulo - CRL 0146.

Fundação CPQD - Centro de Pesquisa e Desenvolvimento em Telecomunicações - CRL 0147

INPE - Instituto Nacional de Pesquisas Espaciais - Laboratório de EMI/EMC/Antenas - CRL 0290

USFC - IEB - Fundação de Amparo á Pesquisa e Extensão Universitária do Instituto de Engenharia Biomédica. - CRL 0319

CERTLAB - Instituto de Certificação Brasileiro - CRL 0347

No Risk Serviços Técnicos Especializados Ltda - CRL 0396

É necessário que os laboratórios de ensaios possuam uma estrutura adequada e capacitada, satisfaçam as exigências dos clientes e das autoridades regulamentadoras e garantam a qualidade dos resultados atendendo às especificações exigidas pela Norma ABNT NBR ISO/IEC 17025:2005. Essas características são atestadas por auditorias anuais realizadas pelo Inmetro. Alguns dos critérios gerais abordados pela Norma ABNT NBR ISO/IEC 17025:2005 são: pessoal gerencial e técnico qualificado para desempenhar suas tarefas; Sistema de 
Gestão adequado; espaço físico que atenda às condições ambientais especificadas pelas Normas Técnicas e que não invalidem os resultados ou afetem a qualidade das medições; políticas para a proteção das informações confidenciais e para assegurar que toda e qualquer pessoa do laboratório esteja livre de pressões indevidas comerciais e/ou financeiras.

O laboratório UFSC-IEB não possui em seu escopo de acreditação pelo Inmetro nenhuma Norma da série ABNT NBR IEC 60601/80601, mas realiza ensaios em equipamentos eletromédicos de acordo com outras Normas Técnicas que não são exigidas nos processos de registro e certificação de equipamentos eletromédicos. Por exemplo, utiliza as Normas ECRI (EMERGENCY CARE RESEARCH INSTITUTE) - Health Devices Inspection and Preventive Maintenance System ${ }^{[6]}$.

Os demais laboratórios realizam ensaios de compatibilidade eletromagnética, ensaios de segurança e desempenho essencial segundo a série de Normas ABNT NBR IEC 60601/80601. Os ensaios de compatibilidade eletromagnética são aplicados a todos os equipamentos eletromédicos, mas são realizados apenas pelos laboratórios CIENTEC, IBEC, INPE e CERTLAB. Os demais laboratórios realizam somente os ensaios de segurança e desempenho essencial. É importante destacar que cada laboratório possui um escopo com uma quantidade de Normas Técnicas e a DEC-LEB/EPUSP possui a maior quantidade de Normas em seu escopo dentre os laboratórios acreditados pelo Inmetro.

\subsubsection{A DEC-LEB/EPUSP}

A Divisão de Ensaios e Calibração (DEC) é uma entidade pertencente ao Laboratório de Engenharia Biomédica (LEB) da Escola Politécnica da Universidade de São Paulo (EPUSP) e desenvolve suas atividades em uma área de cerca de $100 \mathrm{~m}^{2}$ (salas C1-02, D2-22 e D2-05).

A DEC-LEB/EPUSP deu início a suas atividades em 1995 com o objetivo principal de prestar serviços na área de ensaios de produtos médicos, mais especificamente para realizar ensaios de segurança em equipamentos 
eletromédicos visando colaborar com o Ministério da Saúde. A DEC conquistou sua acreditação junto ao Inmetro em 12 de maio de 2003, tornado-se um dos laboratórios pertencentes à RBLE.

É importante ressaltar que ao longo da história da DEC ocorreram atividades que contribuíram para a melhoria dos recursos da área técnica e, principalmente, para o desenvolvimento de recursos humanos. Algumas dessas atividades foram:

- Participação junto à ABNT na elaboração de projetos de Normas, possibilitando assim que o laboratório de ensaios participe da elaboração de Normas ABNT NBR IEC publicadas.

- Contribuição da DEC no desenvolvimento e publicação de diversos trabalhos de mestrado e doutorados.

- Realização de cursos sobre registro, certificação e ensaios de equipamentos eletromédicos.

A principal atividade que a Divisão de Ensaios e Calibração realiza são os ensaios em equipamentos eletromédicos, pois devido às limitações de instrumentos e espaço físico, as atividades de calibração ainda não foram implementadas ${ }^{[7]}$. 0 laboratório atualmente possui um escopo de 40 Normas Técnicas conforme a Tabela 2.2 .

Tabela 2.2 - Escopo de acreditação da DEC-LEB/EPUSP (fonte: Sítio Inmetro 09/jan/2012).

\begin{tabular}{|l|ll|}
\hline \multicolumn{1}{|c|}{ Norma } & \multicolumn{1}{|c|}{ Assunto } \\
\hline ABNT NBR IEC 60601-1:1994 & $\begin{array}{l}\text { Prescrições gerais para a segurança de } \\
\text { equipamentos eletromédicos. }\end{array}$ \\
\hline ABNT NBR IEC 60601-1-1:2004 & $\begin{array}{l}\text { Prescrições gerais para segurança - Norma } \\
\text { colateral: Prescrições de segurança para } \\
\text { sistemas eletromédicos }\end{array}$ \\
\hline ABNT NBR IEC 60601-1-4:2004 & $\begin{array}{l}\text { Prescrições gerais para segurança - Norma } \\
\text { colateral: Prescrições de segurança pra sistemas } \\
\text { eletromédicos programáveis. }\end{array}$ \\
\hline ABNT NBR IEC 60601-2-02:2001 & $\begin{array}{l}\text { Prescrições particulares de segurança de } \\
\text { equipamento cirúrgico de alta freqüência. }\end{array}$ \\
\hline ABNT NBR IEC 60601-2-03:1997 & $\begin{array}{l}\text { Prescrições particulares para a segurança de } \\
\text { equipamento de terapia por ondas curtas. }\end{array}$ \\
\hline ABNT NBR IEC 60601-2-04:2005 & $\begin{array}{l}\text { Prescrições particulares para a segurança de } \\
\text { desfibriladores cardíacos. }\end{array}$ \\
\hline ABNT NBR IEC 60601-2-05:1997 & $\begin{array}{l}\text { Prescrições particulares para segurança de } \\
\text { equipamentos por ultra-som para terapia. }\end{array}$ \\
\hline
\end{tabular}


Tabela 2.2 (continuação) - Escopo de acreditação da DEC-LEB/EPUSP (fonte: Sítio Inmetro 09/jan/2012).

\begin{tabular}{|c|c|}
\hline Norma & Assunto \\
\hline ABNT NBR IEC 60601-2-06:1997 & $\begin{array}{l}\text { Prescrições particulares para segurança de } \\
\text { equipamento de terapia por microondas. }\end{array}$ \\
\hline $\begin{array}{l}\text { ABNT NBR IEC 60601-2-10:1997 e } \\
\text { Emenda de } 2002\end{array}$ & $\begin{array}{l}\text { Prescrições particulares para segurança de } \\
\text { Equipamento para estimulação Neuromuscular. }\end{array}$ \\
\hline ABNT NBR IEC 60601-2-12:2004 & $\begin{array}{l}\text { Prescrições particulares para segurança de } \\
\text { ventilador pulmonar - Ventiladores para cuidados } \\
\text { críticos. }\end{array}$ \\
\hline ABNT NBR IEC 60601-2-13:2004 & $\begin{array}{l}\text { Prescrições particulares para segurança e } \\
\text { desempenho essencial de sistemas de anestesia. }\end{array}$ \\
\hline ABNT NBR IEC 60601-2-14:1998 & $\begin{array}{l}\text { Prescrições particulares para segurança de } \\
\text { equipamento para eletroconvulsoterapia }\end{array}$ \\
\hline ABNT NBR IEC 60601-2-16:2003 & $\begin{array}{l}\text { Prescrições particulares para segurança de } \\
\text { equipamentos de hemodiálise, hemodiafiltração, } \\
\text { e hemofiltração. }\end{array}$ \\
\hline ABNT NBR IEC 60601-2-18:2002 & $\begin{array}{l}\text { Prescrições particulares de segurança para } \\
\text { equipamentos de endoscopia. }\end{array}$ \\
\hline ABNT NBR IEC 60601-2-19:1997 & $\begin{array}{l}\text { Prescrições particulares para segurança de } \\
\text { incubadoras para recém-nascidos (RN). }\end{array}$ \\
\hline ABNT NBR IEC 60601-2-20:1997 & $\begin{array}{l}\text { Prescrições particulares para segurança de } \\
\text { incubadoras de transporte. }\end{array}$ \\
\hline ABNT NBR IEC 60601-2-21:1997 & $\begin{array}{l}\text { Prescrições particulares para a segurança de } \\
\text { berços aquecidos para recém-nascidos. }\end{array}$ \\
\hline ABNT NBR IEC 60601-2-22:1997 & $\begin{array}{l}\text { Prescrições particulares para segurança de } \\
\text { equipamento terapêutico e de diagnóstico a } \\
\text { laser. }\end{array}$ \\
\hline ABNT NBR IEC 60601-2-24:1999 & $\begin{array}{l}\text { Prescrições particulares para bomba } \\
\text { controladores de infusão. }\end{array}$ \\
\hline ABNT NBR IEC 60601-2-25:1997 & $\begin{array}{l}\text { Prescrições particulares para segurança de } \\
\text { eletrocardiógrafos. }\end{array}$ \\
\hline ABNT NBR IEC 60601-2-26:1997 & $\begin{array}{l}\text { Prescrições particulares para segurança de } \\
\text { eletroencefalógrafos. }\end{array}$ \\
\hline $\begin{array}{l}\text { ABNT NBR IEC 60601-2-27:1997 e } \\
\text { IEC 60601-2-27:2005 }\end{array}$ & $\begin{array}{l}\text { Prescrições particulares para a segurança de } \\
\text { equipamento para monitorização } \\
\text { eletrocardiograma. }\end{array}$ \\
\hline $\begin{array}{l}\text { ABNT NBR IEC 60601-2-30:1997 e } \\
\text { IEC 60601-2-30:1999 }\end{array}$ & $\begin{array}{l}\text { Prescrições particulares para a segurança de } \\
\text { equipamento para monitorização automática e } \\
\text { cíclica da pressão sangüínea indireta (não } \\
\text { invasiva). }\end{array}$ \\
\hline
\end{tabular}


Tabela 2.2 (continuação) - Escopo de acreditação da DEC-LEB/EPUSP (fonte: Sítio Inmetro 09/jan/2012).

\begin{tabular}{|c|c|}
\hline Norma & Assunto \\
\hline ABNT NBR IEC 60601-2-31:1998 & $\begin{array}{l}\text { Prescrições particulares para a segurança de } \\
\text { marcapassos cardíacos externos com fonte de } \\
\text { alimentação interna. }\end{array}$ \\
\hline $\begin{array}{l}\text { ABNT NBR IEC 60601-2-34:1997 e } \\
\text { IEC 60601-2-34:2000 }\end{array}$ & $\begin{array}{l}\text { Prescrições particulares para a segurança de } \\
\text { equipamento para monitorização da pressão } \\
\text { sangüínea direta (invasiva). }\end{array}$ \\
\hline ABNT NBR IEC 60601-2-35:2006 & $\begin{array}{llll}\text { Prescrições } & \text { particulares } & \text { para segurança de } \\
\text { cobertores almofadas } & \text { e colchões para } \\
\text { aquecimento } & & & \end{array}$ \\
\hline ABNT NBR IEC 60601-2-36:2006 & $\begin{array}{l}\text { Prescrições particulares para segurança de } \\
\text { equipamento extracorpóreo litotripsia. }\end{array}$ \\
\hline ABNT NBR IEC 60601-2-37:2003 & $\begin{array}{l}\text { Prescrições particulares para segurança de } \\
\text { equipamento de diagnóstico e monitoramento } \\
\text { médico por ultra-som. }\end{array}$ \\
\hline ABNT NBR IEC 60601-2-38:1998 & $\begin{array}{l}\text { Prescrições particulares para segurança de } \\
\text { camas hospitalares operadas eletricamente. }\end{array}$ \\
\hline ABNT NBR IEC 60601-2-40:1998 & $\begin{array}{l}\text { Prescrições particulares para segurança de } \\
\text { eletromiógrafos e equipamento de potencial } \\
\text { evocado. }\end{array}$ \\
\hline ABNT NBR IEC 60601-2-46:2000 & $\begin{array}{l}\text { Prescrições particulares para segurança de } \\
\text { mesas cirúrgicas. }\end{array}$ \\
\hline ABNT NBR IEC 60601-2-47:2003 & $\begin{array}{l}\text { Prescrições particulares para segurança de } \\
\text { sistema de eletrocardiografia ambulatorial. }\end{array}$ \\
\hline ABNT NBR IEC 60601-2-49:2003 & $\begin{array}{l}\text { Prescrições particulares para } \begin{array}{c}\text { segurança de } \\
\text { equipamento } \\
\text { multiparamétrica de paciente. }\end{array} \\
\text { monitorização }\end{array}$ \\
\hline ABNT NBR IEC 60601-2-50:2003 & $\begin{array}{l}\text { Prescrições particulares para segurança de } \\
\text { equipamento de fototerapia. }\end{array}$ \\
\hline ABNT NBR IEC 60601-2-51:2005 & $\begin{array}{l}\text { Prescrições particulares para segurança de } \\
\text { equipamento eletrocardiógrafo de gravação e } \\
\text { análise monocanal e multicanal }\end{array}$ \\
\hline ISO 9919:2005 & $\begin{array}{l}\text { Prescrições particulares para segurança de } \\
\text { equipamentos de oximetria de pulso }\end{array}$ \\
\hline ISO 21647:2004 & $\begin{array}{l}\text { Prescrições particulares para segurança de } \\
\text { monitores de gases respiratórios }\end{array}$ \\
\hline
\end{tabular}




\subsection{A SÉRIE DE NORMAS TÉCNICAS ABNT NBR IEC 60601/80601}

De acordo com a RDC 27 da Anvisa, a série de Normas Técnicas ABNT NBR IEC 60601/80601 deve ser adotada pelos laboratórios de ensaios para que sejam realizados os ensaios que garantam a segurança e o desempenho essencial dos equipamentos eletromédicos. Quando mencionada a série, entende-se que para a realização dos ensaios serão adotadas as Normas Técnicas Brasileiras ABNT NBR IEC 60601-1, Colaterais ABNT NBR IEC 60601-1-xx e Normas Particulares ABNT NBR IEC 60601-2-xx ${ }^{[3]}{ }^{[4]}$. A série de Normas Técnicas também pode ser denominada como ABNT NBR IEC 80601, cuja elaboração é realizada internacionalmente pela ISO e IEC.

A Norma ABNT NBR IEC 60601-1:1997 Prescrições Gerais para Segurança de Equipamentos Eletromédicos, ou Norma Geral como é chamada, especifica requisitos gerais para a avaliação da segurança de todos os equipamentos eletromédicos e prescreve exigências referentes à operação confiável, sendo que todo o texto da Norma Geral serve como base para as prescrições de Normas Colaterais e Particulares ${ }^{[8]}$.

As Normas Colaterais contêm informações que especificam prescrições gerais aplicáveis a uma característica específica de todos os equipamentos, não tratadas completamente na Norma Geral, como por exemplo, a Norma ABNT NBR IEC 60601-1-2 Prescrições gerais para segurança - Norma Colateral: Compatibilidade eletromagnética complementa o texto da Norma Geral relativamente à Compatibilidade Eletromagnética.

As Normas Particulares abordam a segurança e o desempenho essencial de determinados equipamentos, como por exemplo, a Norma ABNT NBR IEC 60601-224:1999 apresenta as prescrições particulares para a segurança de Bombas e Controladores de Infusão, a Norma ABNT NBR IEC 60601-2-18:2002 apresenta prescrições particulares de segurança para equipamento de endoscopia. Atualmente estão disponíveis cerca de 49 Normas Técnicas ABNT NBR da série divididas em Normas Particulares, Colaterais e Geral, como apresentado na Tabela $2.3^{[3][4]}$.

As Emendas são documentos publicados após a verificação de algumas omissões ou falhas encontradas nas Normas, e têm como função alterar uma 
determinada Norma podendo ter ainda o objetivo de identificar aspectos adicionais de segurança e desempenho essencial que não foram cobertos previamente. As Erratas corrigem os textos das Normas.

Tabela 2.3 - Normas publicadas pela ABNT da série 60601 (fonte: Instrução Normativa 3)

\begin{tabular}{|c|c|}
\hline $\begin{array}{l}\text { Norma e ano de } \\
\text { publicação }\end{array}$ & Assunto \\
\hline ABNT NBR IEC 60601-1:1994 & $\begin{array}{l}\text { Prescrições gerais para a segurança de } \\
\text { equipamentos eletromédicos. }\end{array}$ \\
\hline ABNT NBR IEC 60601-2-2: 2001 & $\begin{array}{l}\text { Prescrições particulares de segurança de } \\
\text { equipamento cirúrgico de alta freqüência. }\end{array}$ \\
\hline ABNT NBR IEC 60601-2-3: 1997 & $\begin{array}{l}\text { Prescrições particulares para a segurança de } \\
\text { equipamento de terapia por ondas curtas. }\end{array}$ \\
\hline ABNT NBR IEC 60601-2-4: 2005 & $\begin{array}{l}\text { Prescrições particulares para a segurança de } \\
\text { desfibriladores cardíacos. }\end{array}$ \\
\hline ABNT NBR IEC 60601-2-5: 1997 & $\begin{array}{l}\text { Prescrições particulares para segurança de } \\
\text { equipamentos por ultra-som para terapia. }\end{array}$ \\
\hline ABNT NBR IEC 60601-2-6: 1997 & $\begin{array}{l}\text { Prescrições particulares para segurança de } \\
\text { equipamento de terapia por microondas. }\end{array}$ \\
\hline ABNT NBR IEC 60601-2-7: 2001 & $\begin{array}{l}\text { Prescrições particulares para segurança de } \\
\text { geradores de alta tensão de geradores de raios-X } \\
\text { para diagnóstico médico. }\end{array}$ \\
\hline $\begin{array}{l}\text { ABNT NBR IEC 60601-2-10: } 1997 \\
\text { e Emenda de } 2002\end{array}$ & $\begin{array}{l}\text { Prescrições particulares para segurança de } \\
\text { equipamento para estimulação Neuromuscular. }\end{array}$ \\
\hline ABNT NBR IEC 60601-2-12: 2004 & $\begin{array}{l}\text { Prescrições particulares para segurança de } \\
\text { ventilador pulmonar - Ventiladores para cuidados } \\
\text { críticos. }\end{array}$ \\
\hline ABNT NBR IEC 60601-2-13: 2004 & $\begin{array}{l}\text { Prescrições particulares para segurança e } \\
\text { desempenho essencial de sistemas de anestesia. }\end{array}$ \\
\hline ABNT NBR IEC 60601-2-16: 2003 & $\begin{array}{l}\text { Prescrições particulares para segurança de } \\
\text { equipamentos de hemodiálise, hemodiafiltração, e } \\
\text { hemofiltração. }\end{array}$ \\
\hline ABNT NBR IEC 60601-2-18: 2002 & $\begin{array}{l}\text { Prescrições particulares de segurança para } \\
\text { equipamentos de endoscopia. }\end{array}$ \\
\hline ABNT NBR IEC 60601-2-19: 2000 & $\begin{array}{l}\text { Prescrições particulares para segurança de } \\
\text { incubadoras para recém-nascidos (RN). }\end{array}$ \\
\hline ABNT NBR IEC 60601-2-20: 1998 & $\begin{array}{l}\text { Prescrições particulares para segurança de } \\
\text { incubadoras de transporte. }\end{array}$ \\
\hline ABNT NBR IEC 60601-2-21: 2000 & $\begin{array}{l}\text { Prescrições particulares para a segurança de } \\
\text { berços aquecidos para recém-nascidos. }\end{array}$ \\
\hline
\end{tabular}


Tabela 2.3 (continuação) - Normas publicadas pela ABNT da série 60601 (fonte: Instrução Normativa 3)

\begin{tabular}{|c|c|}
\hline $\begin{array}{l}\text { Norma e ano de } \\
\text { publicação }\end{array}$ & Assunto \\
\hline ABNT NBR IEC 60601-2-22: 1997 & $\begin{array}{l}\text { Prescrições particulares para segurança de } \\
\text { equipamento terapêutico e de diagnóstico a laser. }\end{array}$ \\
\hline ABNT NBR IEC 60601-2-24: 1999 & $\begin{array}{l}\text { Prescrições particulares para bomba } \\
\text { controladores de infusão. }\end{array}$ \\
\hline ABNT NBR IEC 60601-2-25: 2001 & $\begin{array}{l}\text { Prescrições particulares para segurança de } \\
\text { eletrocardiógrafos. }\end{array}$ \\
\hline ABNT NBR IEC 60601-2-26: 1997 & $\begin{array}{l}\text { Prescrições particulares para segurança de } \\
\text { eletroencefalógrafos. }\end{array}$ \\
\hline ABNT NBR IEC 60601-2-27: 1997 & $\begin{array}{l}\text { Prescrições particulares para a segurança de } \\
\text { equipamento para } \\
\text { eletrocardiograma. }\end{array}$ \\
\hline ABNT NBR IEC 60601-2-28: 2001 & $\begin{array}{l}\text { Prescrições particulares para segurança } \\
\text { aplicáveis aos conjuntos-fontes de radiação } X \text { e } \\
\text { aos conjuntos-emissores de radiação } X \text { para } \\
\text { diagnóstico médico. }\end{array}$ \\
\hline ABNT NBR IEC 60601-2-30: 1997 & $\begin{array}{l}\text { Prescrições particulares para a segurança de } \\
\text { equipamento para monitorização automática e } \\
\text { cíclica da pressão sangüínea indireta (não } \\
\text { invasiva) }\end{array}$ \\
\hline ABNT NBR IEC 60601-2-31: 1998 & $\begin{array}{l}\text { Prescrições particulares para a segurança de } \\
\text { marcapassos cardíacos externos com fonte de } \\
\text { alimentação interna }\end{array}$ \\
\hline ABNT NBR IEC 60601-2-32: 2001 & $\begin{array}{l}\text { Prescrições particulares para segurança dos } \\
\text { equipamentos associados aos equipamentos de } \\
\text { raios } X \text {. }\end{array}$ \\
\hline ABNT NBR IEC 60601-2-34: 1997 & $\begin{array}{l}\text { Prescrições particulares para a segurança de } \\
\text { equipamento para monitorização da pressão } \\
\text { sangüínea direta (invasiva). }\end{array}$ \\
\hline ABNT NBR IEC 60601-2-35: 2006 & $\begin{array}{l}\text { Prescrições particulares para segurança no uso } \\
\text { médico de cobertores, almofadas e colchões } \\
\text { destinados para o aquecimento. }\end{array}$ \\
\hline ABNT NBR IEC 60601-2-36: 2006 & $\begin{array}{l}\text { Equipamento eletromédico - Parte } 36 \text { : Prescrições } \\
\text { particulares para segurança de equipamento } \\
\text { extracorpóreo para litotripsia induzida. }\end{array}$ \\
\hline ABNT NBR IEC 60601-2-37: 2003 & $\begin{array}{l}\text { Prescrições particulares para segurança de } \\
\text { equipamento de diagnóstico e monitoramento } \\
\text { médico por ultra-som. }\end{array}$ \\
\hline
\end{tabular}


Tabela 2.3 (continuação) - Normas publicadas pela ABNT da série 60601 (fonte: Instrução Normativa 3)

\begin{tabular}{|c|c|}
\hline $\begin{array}{l}\text { Norma e ano de } \\
\text { publicação }\end{array}$ & Assunto \\
\hline ABNT NBR IEC 60601-2-38: 1998 & $\begin{array}{l}\text { Prescrições particulares para segurança de camas } \\
\text { hospitalares operadas eletricamente. }\end{array}$ \\
\hline ABNT NBR IEC 60601-2-40: 1998 & $\begin{array}{l}\text { Prescrições particulares para segurança de } \\
\text { eletromiógrafos e equipamento de potencial } \\
\text { evocado. }\end{array}$ \\
\hline ABNT NBR IEC 60601-2-43: 2004 & $\begin{array}{l}\text { Prescrições particulares para a segurança de } \\
\text { equipamento de raios- } X \text { para procedimento } \\
\text { intervencionista. }\end{array}$ \\
\hline ABNT NBR IEC 60601-2-45: 2005 & $\begin{array}{l}\text { Prescrições particulares para a segurança de } \\
\text { equipamento de raios- } X \text { mamográfico e } \\
\text { dispositivos de estereotaxia mamográfica. }\end{array}$ \\
\hline ABNT NBR IEC 60601-2-46: 2000 & $\begin{array}{l}\text { Prescrições particulares para segurança de mesas } \\
\text { cirúrgicas. }\end{array}$ \\
\hline ABNT NBR IEC 60601-2-47: 2003 & $\begin{array}{l}\begin{array}{l}\text { Prescrições particulares para } \\
\text { desempenho essencial de } \\
\text { eletrocardiografia ambulatorial. }\end{array} \\
\text { sistema }\end{array}$ \\
\hline ABNT NBR IEC 60601-2-49: 2003 & $\begin{array}{l}\text { Prescrições particulares para segurança de } \\
\text { equipamento para monitorização multiparamétrica } \\
\text { de paciente. }\end{array}$ \\
\hline ABNT NBR IEC 60601-2-50: 2003 & $\begin{array}{l}\text { Prescrições particulares para segurança de } \\
\text { equipamento de fototerapia. }\end{array}$ \\
\hline ABNT NBR IEC 60601-2-51: 2003 & 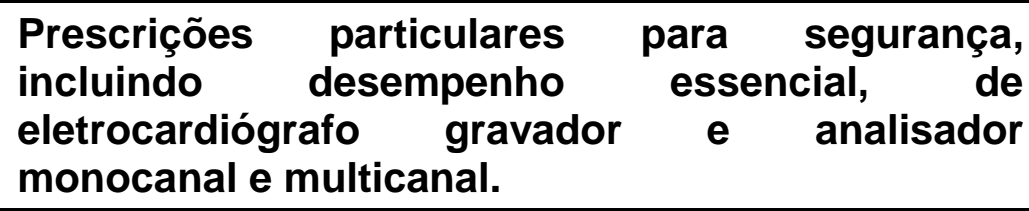 \\
\hline ABNT NBR IEC 60601-1-1: 2004 & $\begin{array}{l}\text { Prescrições gerais para segurança - Norma } \\
\text { colateral: Prescrições de segurança para sistemas } \\
\text { eletromédicos. }\end{array}$ \\
\hline ABNT NBR IEC 60601-1-2: 2006 & $\begin{array}{l}\text { Prescrições gerais para segurança - Norma } \\
\text { colateral: Compatibilidade eletromagnética } \\
\text { Prescrições e ensaios. }\end{array}$ \\
\hline ABNT NBR IEC 60601-1-3: 2001 & $\begin{array}{l}\text { Prescrições gerais de segurança - Norma } \\
\text { colateral: Prescrições gerais para proteção contra } \\
\text { radiação de equipamentos de raios X para fins } \\
\text { diagnósticos }\end{array}$ \\
\hline ABNT NBR IEC 60601-1-4: 2004 & $\begin{array}{l}\text { Prescrições gerais para segurança - Norma } \\
\text { colateral: Sistemas eletromédicos programáveis. }\end{array}$ \\
\hline
\end{tabular}


Tabela 2.3 (continuação) - Normas publicadas pela ABNT da série 60601 (fonte: Instrução Normativa 3)

\begin{tabular}{|l|l|}
\hline \multicolumn{1}{|c|}{$\begin{array}{c}\text { Norma e ano de } \\
\text { publicação }\end{array}$} & \multicolumn{1}{c|}{ Assunto } \\
\hline ABNT NBR IEC 1689: 1998 & $\begin{array}{l}\text { Ultra-Som Sistemas de Fisioterapia - Prescrições } \\
\text { para desempenho e métodos de medição na faixa } \\
\text { de freqüências de 0,5 MHz a 5 MHz. }\end{array}$ \\
\hline ABNT NBR ISO 7785-1: 1999 & $\begin{array}{l}\text { Peças de mão odontológicas - Turbinas de Ar de } \\
\text { Alta Rotação Odontológica }\end{array}$ \\
\hline ABNT NBR ISO 7785-2: 2004 & $\begin{array}{l}\text { Peças de mão odontológicas - Peças de Mão retas } \\
\text { e angulares }\end{array}$ \\
\hline ABNT NBR ISO 9919: 1997 & Oxímetros \\
\hline ABNT NBR ISO 11195: 2000 & Misturador de Gases Medicinais \\
\hline ABNT NBR ISO 9680: 2001 & Aparelho de lluminação Bucal \\
\hline ABNT NBR ISO 6875: 1998 & Cadeira Odontológica \\
\hline ABNT NBR ISO 8835-2: 2010 & Sistema de Anestesia por Inalação \\
\hline
\end{tabular}

As disposições das numerações das Seções e Subseções das Normas Colaterais e Particulares correspondem às mesmas da Norma Geral. É importante destacar que os textos das Normas Particulares, em algumas seções e subseções poderão apresentar algumas modificações que são expressas por alguns termos de interpretação crítica, como por exemplo, a palavra "substituir" significa que a seção ou subseção da Norma Geral é substituída completamente pelo texto da Norma Particular; "acrescentar" significa que o texto da Norma Particular é acrescentado ao da Norma Geral; "modificar" significa que a seção ou subseção da Norma Geral é modificada como indicado no texto da Norma Particular.

Todas as seções, subseções, tabelas e figuras acrescentadas as Normas Particulares são numeradas começando por 101 e os anexos são nomeados por AA, BB, CC e assim por diante. Os itens acrescentados são especificados como aa), bb), cc) e assim sucessivamente. 


\subsection{A NORMA ABNT NBR IEC 60601-1:1997}

A Norma Geral ABNT NBR IEC 60601-1:1997 intitulada "Prescrições Gerais para Segurança" é composta por: prefácio, introdução, dez seções e anexos. Todas as seções contêm seções e subseções correspondentes a ensaios específicos. $O$ leitor, ao analisar uma Norma Técnica, deparar-se-á com as seguintes características nas seções:

- Seção Um: Generalidades

A seção um explica os campos de aplicação da Norma e os seus objetivos, apresenta explicações dos termos escritos em letra maiúsculas empregados nos textos da Norma, e alguns ensaios a serem realizados, como o da Cláusula 6 sobre Prescrições de conformidade referente à Identificação de Símbolos, Marcação e Documentos Acompanhantes e o da Cláusula 7 sobre Potência de Entrada.

- Seção Dois: Condições Ambientais

A seção dois apresenta condições ambientais e gerais para realização dos ensaios na Cláusula 10.

- Seção Três: Proteção Contra Risco de Choque Elétrico

A seção três é dedicada a ensaios referentes à proteção elétrica, como exemplo, a Cláusula 15: Limitação de Tensão ou Energia, Cláusula 18: Aterramento de Proteção, Cláusulas 19 e 20: Correntes de Fuga e Rigidez Dielétrica.

- Seção Quatro: Proteção Contra Riscos Mecânicos

A seção quatro apresenta ensaios relativos à proteção mecânica. Por exemplo, a Cláusula 21 sobre Ensaios de Resistência Mecânica a Cláusula 22 sobre Partes Móveis, Cláusula 23 sobre Superfícies Ângulos e Arestas e a Cláusula 24 sobre Estabilidade em Utilização Normal. 
- Seção Cinco: Proteção Contra Risco de Radiação indesejada ou excessiva.

A seção cinco apresenta ensaios correspondentes à Risco de Radiação indesejada ou excessiva, como a radiação $\mathrm{X}$, radiação gama, radiação por microondas, dentre outras.

- Seção Seis: Proteção contra risco de ignição de misturas anestésicas inflamáveis.

As cláusulas 39 e 40 da seção seis apresentam prescrições e ensaios para equipamentos de categoria $\mathrm{AP}$ ou $\mathrm{APG}$.

Conforme descrito na própria Norma Geral, equipamento de categoria AP é aquele que está em conformidade quanto à construção, marcação e documentação com as prescrições especificadas para evitar o aparecimento de fontes de ignição em uma mistura anestésica inflamável com o ar. O equipamento de categoria APG é aquele que está em conformidade quanto à construção, marcação e documentação com as prescrições especificadas para evitar o aparecimento de fontes de ignição em uma mistura anestésica inflamável com oxigênio ou óxido nitroso.

- Seção Sete: Proteção contra Temperatura Excessiva e outros riscos de Segurança.

A seção sete determina ensaios para proteção contra temperaturas excessivas, como por exemplo, Cláusula 42 sobre Temperaturas excessivas, a Cláusula 43 sobre Prevenção contra fogo e a Cláusula 49 sobre Interrupção no fornecimento de Energia.

- Seção Oito: Exatidão de Dados de Operação e Proteção contra característica de saída incorreta

As cláusulas 50 e 51 da seção oito apresentam prescrições referentes à proteção contra característica de saída incorreta e operação anormal e condições de falha. A seção oito é normalmente alterada pelos textos das Normas Particulares. 
- Seção Nove: Operação Anormal e condições de falha

A seção é destinada a ensaios de aplicação e investigação de falhas no equipamento, como por exemplo, a cláusula 52 sobre operação anormal e condições de falha.

- Seção Dez: Prescrições para construção.

$\mathrm{Na}$ seção dez são prescritas cláusulas para verificação das construções elétrica e mecânica do equipamento. Por exemplo, a cláusula 54 sobre gabinetes e tampas e a cláusula 56 sobre parte a ser ligada à rede, componentes e leiaute.

Os anexos da Norma Geral são necessários para orientar o leitor e possuem caráter explicativo, a menos que certo grau de obrigatoriedade seja imposto por declaração explícita na Norma. $\mathrm{O}$ anexo A, por exemplo, possui apenas informações adicionais e justificativas para as cláusulas marcadas com um asterisco ao longo de toda a Norma. $\mathrm{O}$ anexo $\mathrm{C}$ recomenda a sequência de trinta e seis ensaios que devem ser realizados pelos laboratórios de ensaios.

Os anexos da Norma Geral são onze, assim definidos:

- Anexo A: Diretrizes Gerais e Justificativas

- Anexo B: Ensaio durante a fabricação e/ou instalação.

- Anexo C: Sequência de Ensaios

- Anexo D: Simbologia para Marcação.

- Anexo E: Inspeção de Caminhos de Isolação e Circuitos de Ensaio

- Anexo F: Aparelho de ensaio para Misturas Inflamáveis

- Anexo G: Aparelho de Ensaio de Impacto

- Anexo H: Ligações por terminais Parafusados

- Anexo J: Transformadores de Alimentação

- Anexo K: Exemplos de Conexões de Parte Aplicada para Medição de Corrente de Fuga Através do Paciente.

- Anexo L: Referências Bibliografias.

Outra condição imposta por esta Norma é em relação à definição de algumas formas verbais. Por exemplo, "deve" significa que a conformidade com a exigência ou ensaio em questão é obrigatória para que haja conformidade; "deveria" significa 
que a conformidade com a exigência ou ensaio em questão é fortemente recomendada, mas não obrigatória; "pode" significa que a conformidade com a exigência ou ensaio em questão é apenas uma maneira particular de se obter a conformidade.

\subsection{A NORMA ABNT NBR IEC 60601-1:2010}

A nova edição da Norma Geral possui o título de Requisitos Gerais para a Segurança Básica e Desempenho Essencial de Equipamentos Eletromédicos. Esta Norma requer que o fabricante implemente um processo de Gerenciamento de Risco em conformidade com a Norma ABNT NBR ISO 14971:2009 e, desta forma, é imprescindível que o pessoal envolvido nesta atividade tenha conhecimento do conteúdo das duas Normas e esteja familiarizado com os termos empregados para posteriormente iniciar as atividades e avaliações.

Ao analisar a nova edição da Norma Geral, o leitor se deparará com a seguinte estrutura:

- Seção quatro: Requisitos Gerais.

Nesta seção há informações gerais para o processo de Gerenciamento de Risco, desempenho essencial, vida útil esperada.

- Seção cinco: Requisitos Gerais para ensaios em equipamentos eletromédicos.

Nesta seção são apresentadas informações para a realização dos ensaios, por exemplo, temperatura, umidade e pressão atmosférica que precisam estar no laboratório. Além de outras informações, por exemplo, como prosseguir com os ensaios caso haja a necessidade de reparos e a sequência dos mesmos. 
- Seção seis: Classificação

Nesta seção são encontradas informações para classificação dos equipamentos eletromédicos, por exemplo, contra choque elétrico: se é classe I ou classe II, proteção contra penetração de água: IPX1, IPX2, etc.

O equipamento de classe I é aquele no qual a proteção contra choque elétrico não se fundamenta apenas na proteção básica, mas incorpora ainda uma precaução de segurança adicional, consistindo em um recurso de conexão do equipamento ao condutor de aterramento para a proteção pertencente à fiação fixa da instalação, de modo a impossibilitar que partes metálicas acessíveis possam ficar sob tensão na ocorrência de uma falha na proteção básica. Já o equipamento de classe II é aquele no qual a proteção contra choque elétrico não se fundamenta apenas na proteção básica, mas incorpora precauções de segurança adicionais, como isolação dupla ou isolação reforçada, não comportando recursos de aterramento, nem dependendo de condições de instalação.

O código IPX é utilizado para classificar gabinetes à prova de água, por exemplo, equipamento classificado como IPX1 é aquele protegido contra quedas verticais de gotas de água, enquanto o IPX2 é aquele protegido contra quedas verticais de gotas de água com inclinação máxima de 15․

- Seção sete: Identificação, marcação e documentos

Nesta seção são apresentadas diretrizes, as quais os fabricantes devem aplicar tanto no equipamento como na documentação. Especificações de símbolos, advertências, marcação sobre o equipamento e exigência de informações nos documentos acompanhantes são apresentadas neste item.

- Seção oito: Proteção contra perigos elétricos

Nesta seção são descritos todos os ensaios elétricos que devem ser realizados, por exemplo, corrente de fuga, rigidez dielétrica, tensão residual, ensaio de aterramento, potência de entrada e uma série de outros. Juntamente com esses ensaios, é necessário fazer uma análise minuciosa nos arquivos de Gerenciamento de Risco, verificando como o fabricante utilizou a Norma ABNT NBR ISO 14971:2009 para diminuir o risco associado a este tipo de condição que o equipamento estará sujeito durante sua utilização. 
- Seção Nove: Proteção contra Perigos Mecânicos

Nesta seção são apresentados ensaios mecânicos, como por exemplo, ensaios de impacto, dispositivo de parada de emergência, perigos de instabilidade. Juntamente com esses ensaios, é necessário verificar os arquivos de Gerenciamento de Risco.

- Seção Dez: Proteção contra Perigos de radiação excessiva indesejável.

Nesta seção são prescritos ensaios relacionados à radiação $X$, alfa, beta, gama e de nêutrons, radiação de microondas, lasers, radiação infravermelha e ultravioleta.

- Seção Onze: Proteção contra temperaturas excessivas e outros perigos.

Nesta seção são apresentados ensaios de máxima temperatura durante utilização normal, prevenção contra fogo, conexões elétricas em ambientes ricos em oxigênio, vazamento, biocompatibilidade, limpeza, esterilização e desinfecção.

- Seção Doze: Exatidão de Controles e Proteção contra Saída Incorreta. Nesta seção são prescritos vários ensaios relacionados a Gerenciamento de Risco, ou seja, há a necessidade de fazer análise nos arquivos fornecidos pelo fabricante.

- Seção Treze: Situações Perigosas e Condições de Falha.

Nesta seção são prescritos ensaios para emissões, deformação do gabinete, condições de falhas, por exemplo, em dispositivos limitadores de temperatura.

- Seção Quatorze: Sistemas Eletromédicos Programáveis.

Nesta seção são apresentados ensaios que foram incorporados da Norma ABNT NBR IEC 60601-1-4:2004.

- Seção Quinze: Construção do Equipamento Eletromédico.

Nesta seção são prescritos ensaios para avaliar o equipamento em relação à resistência ao desgaste mecânico, degradação elétrica, degradação ambiental, 
envelhecimento, além de ensaios de impacto, queda, análise de componentes tanto elétricos quanto mecânicos, ensaios em transformadores.

- Seção Dezesseis: Sistemas Eletromédicos

Nesta seção são apresentados ensaios que foram incorporados da Norma ABNT NBR IEC 60601-1-1:2004.

- Seção Dezessete: Compatibilidade Eletromagnética

Nesta seção são apresentadas informações de Compatibilidade Eletromagnética, a serem complementadas na Norma Colateral ABNT NBR IEC 60601-1-2.

\subsubsection{Requisitos Gerais do processo de Gerenciamento de Risco para Equipamentos Eletromédicos ou Sistemas Eletromédicos conforme a Norma ABNT NBR IEC 60601-1:2010}

Na aplicação da Norma ABNT NBR ISO 14971:2009 para a realização dos ensaios conforme a Norma ABNT NBR IEC 60601-1:2010, as seguintes condições devem ser consideradas:

- O termo produto para a saúde deve assumir o mesmo significado que equipamento eletromédico ou sistema eletromédico.

- A política para a determinação do risco aceitável e da aceitabilidade dos riscos residuais deve ser estabelecida pelo fabricante.

- Quando a Norma Geral ou quaisquer umas de suas Normas Colaterais ou Particulares especificarem requisitos verificáveis relacionados a riscos particulares, e esses requisitos forem cumpridos, os riscos residuais relacionados a esses requisitos são presumidos aceitáveis, a menos que haja evidência objetiva do contrário.

Ao utilizar a Norma Geral o leitor deve notar que ela especifica requisitos que são, de uma maneira geral, os riscos associados com equipamento eletromédico e 
se destina a servir como uma ferramenta no processo de Gerenciamento de Risco. Convém comentar que todo o processo deve identificar não apenas aqueles perigos abrangidos pela Norma Geral, mas tentar expandir e identificar todos aqueles relacionados com o equipamento em questão.

Para a avaliação da conformidade, o examinador deve fazer a inspeção do arquivo de Gerenciamento de Risco e considerar os resultados como satisfatórios se o fabricante estabeleceu um processo de Gerenciamento de Risco, estabeleceu níveis aceitáveis de risco e demonstrou que os riscos residuais são aceitáveis de acordo com a política para a sua determinação ${ }^{[1]}$.

\subsubsection{Requisitos Gerais para ensaios em Equipamentos Eletromédicos}

Todos os ensaios descritos na Norma Geral são ensaios de tipo, ou seja, ensaios que são realizados em uma amostra representativa do equipamento para determinar se o mesmo, conforme projetado e fabricado, pode satisfazer os requisitos.

Os ensaios são realizados dentro da faixa de condições ambientais indicadas na descrição técnica encontrada no manual de instruções do equipamento. Neste item é importante proteger o equipamento eletromédico de outras influências, por exemplo, correntes de ar, temperatura, umidade e pressão, pois podem influenciar nos resultados.

Outro item importante é que o equipamento eletromédico deve ser ensaiado sob as condições de operação menos favoráveis, como especificado nas instruções de utilização que são identificadas durante a análise de risco.

Se houver a necessidade de reparos, reparos após uma falha ou uma probabilidade de falha futura durante a sequência de ensaios, o laboratório de Ensaio e o fabricante podem concordar ou pela apresentação de uma nova amostra na qual todos os ensaios que influenciam os resultados são realizados novamente ou, preferencialmente, pela realização dos reparos ou modificações necessários, após os quais apenas os ensaios pertinentes devem ser repetidos ${ }^{[1]}$. 


\subsubsection{Requisitos para Equipamentos com um Subsistema Eletrônico Programável.}

Como descrito anteriormente neste trabalho, assuntos prescritos pela Norma ABNT NBR IEC 60601-1-4:2004 foram incorporados à nova edição da Norma Geral. Para equipamentos que incorporam um subsistema eletrônico programável, ou seja, "um sistema baseado em uma ou mais unidades centrais de processamento, incluindo o respectivo software e interfaces" (ABNT NBR IEC 60601-1:2010, p.25), as seguintes prescrições devem ser adotadas:

- Um sumário do Gerenciamento de Risco seja prescrito para assegurar que os riscos de perigo identificados sejam controlados. $O$ sumário do Gerenciamento de Risco deve ser completado na conclusão do ciclo de vida do produto.

- Um ciclo de vida de desenvolvimento deve ser prescrito para garantir que a segurança seja tratada em um modo sistemático e, em particular, para possibilitar identificações antecipadas de perigo em sistemas complexos.

Um sistema definido para resolução de problemas é requerido, porque aproximações para este fim podem trazer seus próprios problemas. Problemas antecipados incluem requisitos inconsistentes ou ambíguos, especificações não indicadas e bugs encontrados durante avaliações ${ }^{[1][9]}$.

\subsection{GERENCIAMENTO DE RISCO E A NORMA ABNT NBR ISO 14971:2009}

\subsubsection{Definição de Risco}

Segundo a British Standard - BS 6079-1(2000) risco é uma combinação da probabilidade ou frequência da ocorrência de uma ameaça ou oportunidade e a 
magnitude das consequências desta ocorrência. Os riscos se manifestam na forma de incerteza que cercam os processos de um projeto ${ }^{[10]}$.

O risco também pode ser definido como a medida da probabilidade e consequência de não se alcançar uma meta definida do projeto e também que o risco é constituído da falta de conhecimentos de eventos futuros envolvendo a noção de incerteza. Tipicamente, eventos futuros favoráveis são chamados de oportunidades e os desfavoráveis são chamados de risco [10], [11].

Outra definição de risco é a exposição às consequências da incerteza. Em um contexto de projeto, é a chance de algo acontecer e que terá um impacto sobre os objetivos. Inclui a possibilidade de perda ou ganho como uma consequência da incerteza associada seguindo uma ação particular. Risco tem dois elementos: a probabilidade de algo acontecer e as consequências e impactos que ele acarreta ${ }^{[12]}$.

Segundo a Norma ABNT NBR ISO 14971:2009, risco pode ser definido como combinação da probabilidade de ocorrência de um dano e a severidade de tal dano ${ }^{[13]}$.

\subsubsection{Gerenciamento de Risco}

O Gerenciamento de Risco é definido como uma forma organizada de identificar e medir os riscos além de desenvolver, selecionar e gerenciar as opções para seu controle ${ }^{[14]}$.

Gerenciamento de Risco é um processo que é realizado durante todo o ciclo de vida do produto e depende da metodologia usada para monitorar e controlar os riscos. Gerenciamento de Risco é o processo para identificar, avaliar e responder aos riscos que estão associados ao sucesso do produto ${ }^{[15]}$.

Através do Gerenciamento de Risco pode-se acumular conhecimento e aumentar a confiança nas informações que dão suporte à tomada de decisões, harmonizando decisões melhores de planejamento, ao prevenir ou mitigar riscos, proporcionando uma melhor visão para lidar com riscos e seus impactos ${ }^{[11]}$. 
Os processos de Gerenciamento de Risco interagem com outros processos de gerenciamento de projetos continuamente, não só na fase inicial, mas durante o ciclo de vida do projeto e do produto ${ }^{[10]}$.

O objetivo do Gerenciamento de Risco é a redução de riscos de um projeto, auxiliar na eleição de prioridades, alocando recursos e implementando ações e processos que possam reduzir o risco de não alcançar os objetivos do projeto ou do produto $^{[12][16]}$.

Ao longo dos anos surgiram diferentes abordagens para o processo de Gerenciamento de Risco. A seguir serão apresentadas quatro abordagens amplamente utilizadas $^{[11][15][17]}$ :

- AS/NZS (Australian and New Zealand Standard) 4360:2004 - Risk Management

A Norma AS/NZS é genérica para Gerenciamento de Risco, e não fica restrita só a projetos, podendo ser utilizada em todos os níveis das atividades individuais ao negócio como um todo.

A Norma descreve uma abordagem completa de Gerenciamento de Risco, não só para análise ou avaliação de risco. Administra a integração entre os processos de Gerenciamento de Risco e diretrizes estratégicas. As principais características desta Norma são apresentadas na Figura 2.1.

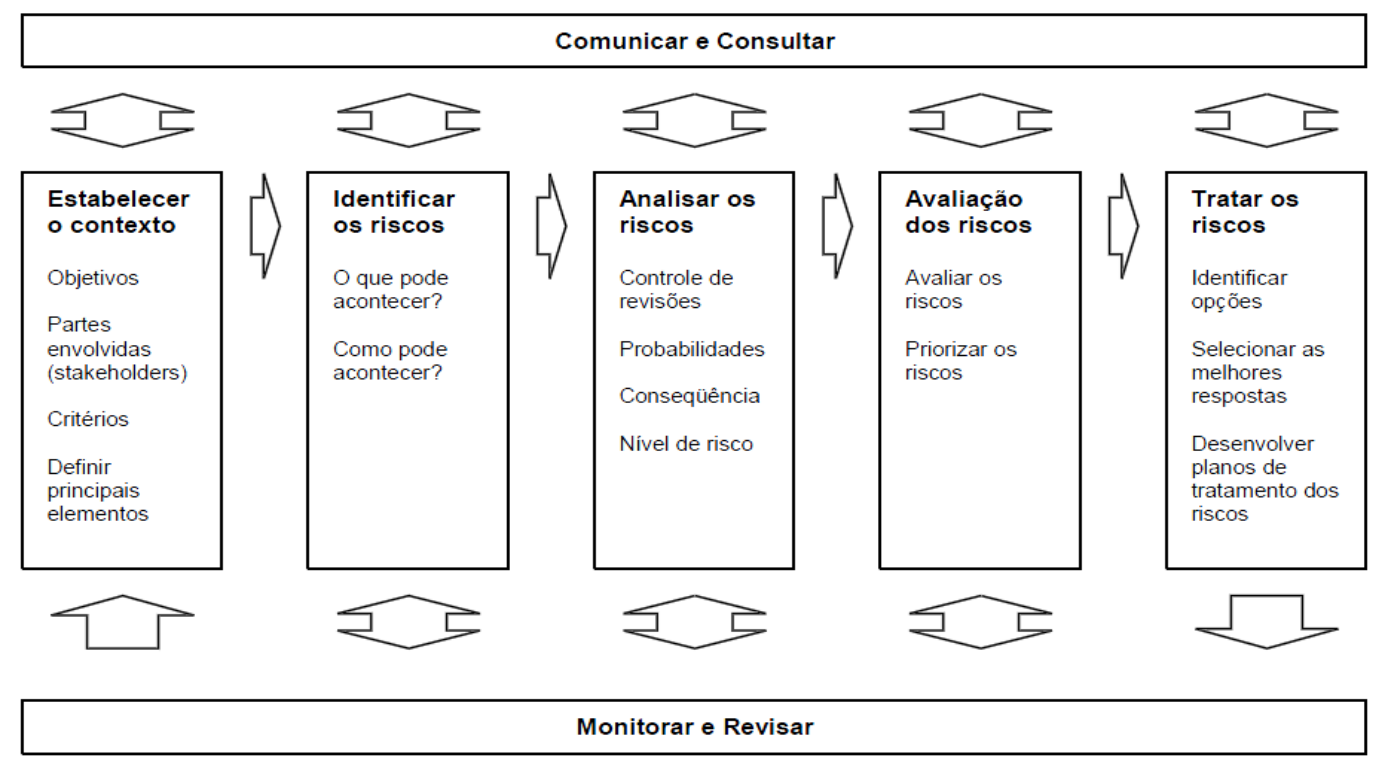

Figura 2.1- Etapas do processo de Gerenciamento de Risco de Acordo com a Norma AS/NZS 4360:2004 
- PRAM guide - Project Risk Analysis and Management (UK Association for Project Management)

O guia PRAM é especificamente orientado ao Gerenciamento de Risco de projetos, separa os processos de Gerenciamento de Risco de técnicas ou métodos que podem ser utilizados para implementar outras fases do processo. A Figura 2.2 apresenta resumidamente o processo de Gerenciamento de Risco segundo o PRAM.

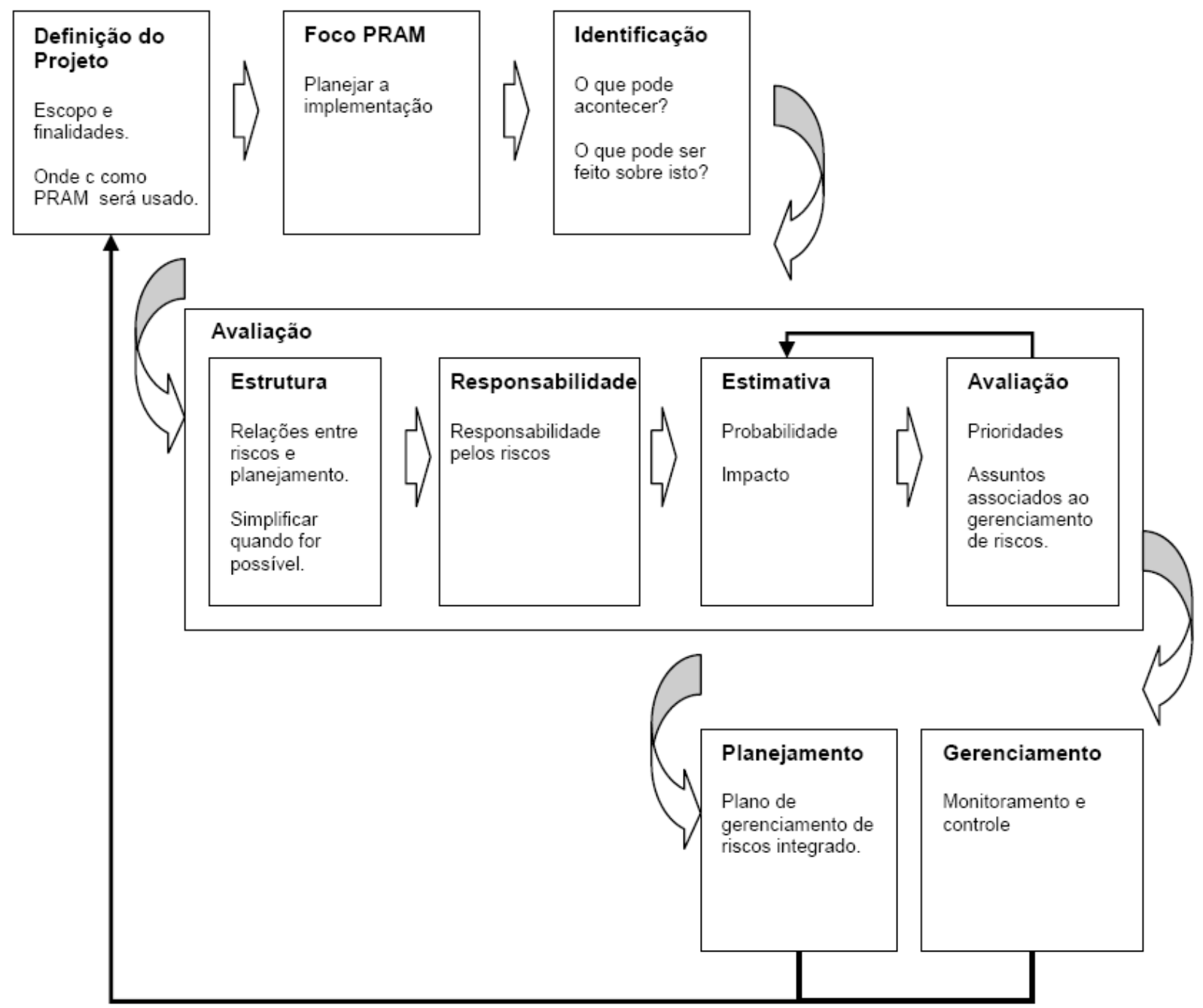

Figura 2.2- Etapas do processo de Gerenciamento de Risco segundo PRAM.

Fonte: Navarro (2007). 
- M_o_R guideline - Management of Risk (UK Office of Government Commerce)

O guia M_o_R foi escrito por organizações do setor público do Reino Unido, com ênfase nos riscos relacionados ao sucesso destas organizações, e inclui orientações de processos de orientações de Gerenciamento de Riscos, estrutura de gerenciamento, regras e responsabilidades, assim com um checklist que auxilia as várias fases do processo.

Do mesmo modo que o guia PRAM separa os processos de técnicas e ferramentas específicas, o guia M_o_R separa os processos gerais de Gerenciamento de Risco de detalhes de sua implementação no que se refere ao contexto estratégico, de programas, de projetos e operacional, de ferramentas e métodos específicos que podem ser empregados para executar parte deste processo. Os processos descritos no M_o_R são apresentados na Figura 2.3:

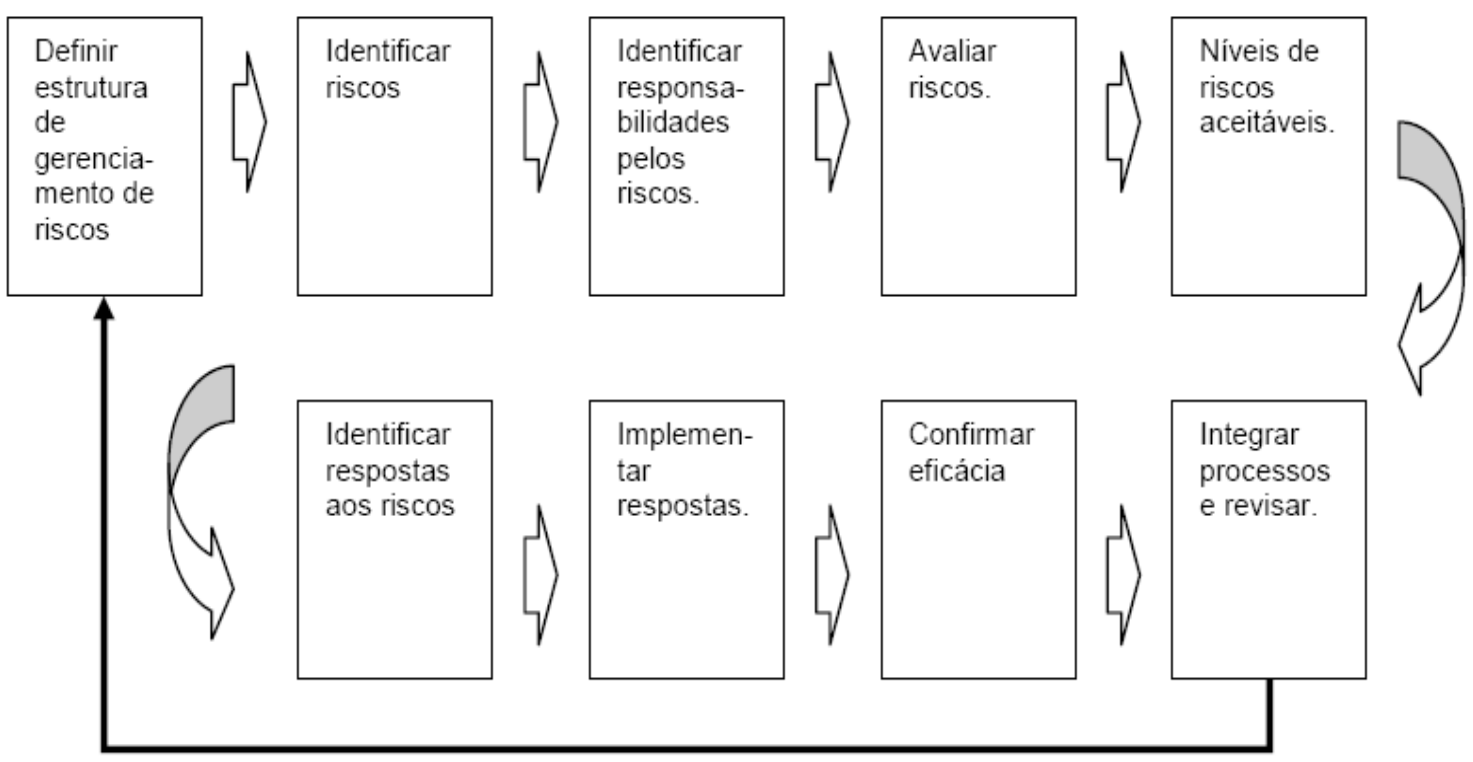

Figura 2.3 - Etapas do processo de Gerenciamento de Risco segundo o guia M_o_R Fonte: Navarro (2007).

- PMBOK 2004 - Project Management Body of Knowledge, PMI - Project Management Institute.

O guia PMBOK é um conjunto de práticas em gerência de projetos publicado pelo PMI (Project Management Institute) e constitui a base do conhecimento em gerência de projetos. Estas práticas são compiladas na forma de um guia. A Figura 
2.4 apresenta o processo de Gerenciamento de Risco segundo o Guia PMBOK 2004.

Um dos capítulos do guia, mas especificamente o capítulo 11 é escrito para o Gerenciamento de Risco. É estruturado considerando dados de entrada, recomendações de técnicas e ferramentas e dados de saída. Destaca a responsabilidade do gerenciamento dos processos e relaciona-os a outros processos de gerenciamento descritos no PMBOK, como gerenciamento de integração, escopo, comunicações, aquisições, custo e prazo.

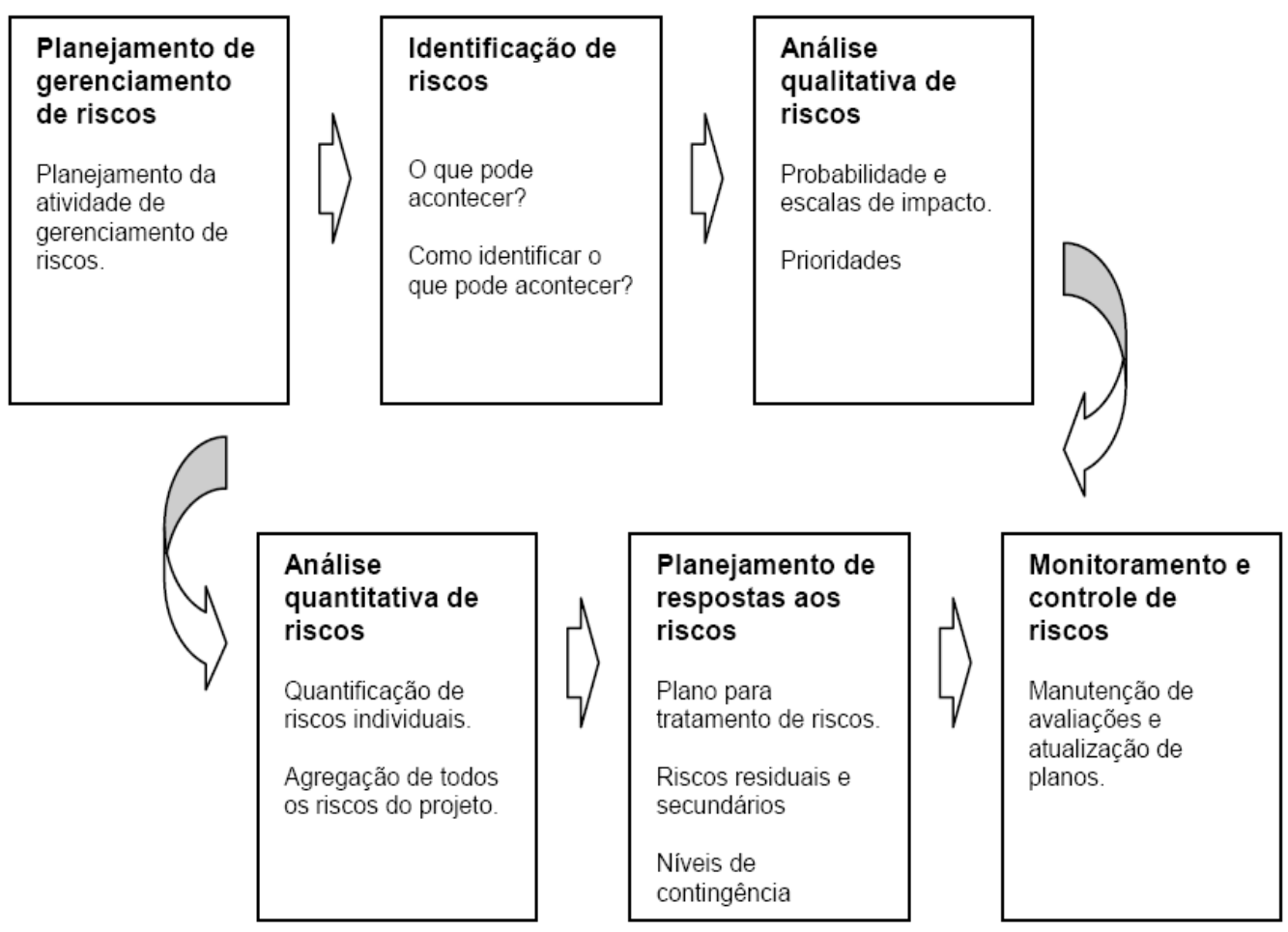

Figura 2.4 - Etapas do processo de Gerenciamento de Risco segundo o guia PMBOK 2004 Fonte: Navarro (2007). 


\subsubsection{Quando deve e quando não deve ser aplicado o Gerenciamento de Risco}

A eficácia do uso do Gerenciamento de Risco tende a diminuir conforme o tempo passa, portanto é benéfico usá-lo nos estágios de projeto e desenvolvimeto de um determinado produto.

Não existem circunstâncias específicas em que o Gerenciamento de Risco e outras técnicas de gestão não devam ser usadas, exceto, talvez, para projetos de repetição, onde tais análises já foram realizadas, a menos que existam diferenças específicas entre os projetos. Na presença de incerteza, onde severas restrições dão origem a um risco significativo, a ausência de dados relevantes poderá fazer uma avaliação quantitativa não valer à pena. No entanto, tais circunstâncias não devem impedir uma rigorosa análise qualitativa ${ }^{[12][16]}$.

\subsubsection{Gerenciamento de Risco de acordo com a Norma ABNT NBR ISO 14971:2009}

A Norma ABNT NBR ISO 14971:2009 - Aplicação do Gerenciamento de Risco para Dispositivos Médicos - especifica um processo para o fabricante identificar os riscos associados aos dispositivos médicos e o controle destes riscos.

O Gerenciamento de Risco é "a aplicação sistemática de políticas, procedimentos e práticas de gerenciamento das tarefas de análise, avaliação, controle e monitoração de risco" (ABNT NBR ISO 14971:2009, p. 7).

Esta Norma é amplamente utilizada por empresas para realizar o Gerenciamento de Risco em produtos para saúde e é a base dos textos da nova edição da Norma Geral da série 60601.

A Figura 2.5 apresenta o processo de Gerenciamento de Risco conforme a ANBT NBR ISO 14971:2009. 


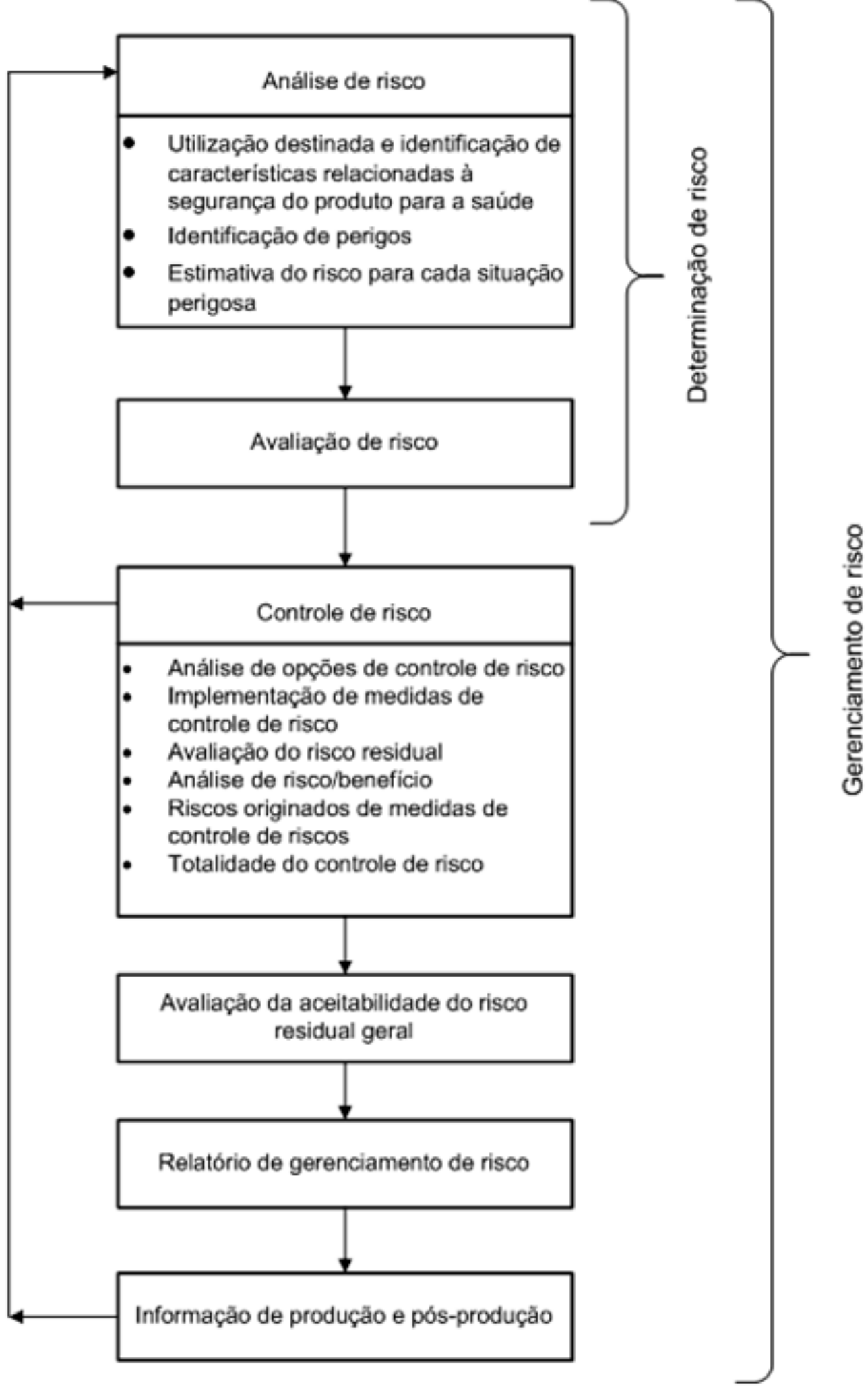

Figura 2.5 - Processo de Gerenciamento de Risco segundo a Norma ABNT NBR ISO 14971:2009 Fonte: ABNT NBR ISO 14971:2009 


\subsubsection{O objetivo do Gerenciamento de Risco aplicado a Equipamentos Eletromédicos.}

O objetivo principal do Gerenciamento de Risco é proteger a saúde e a segurança dos pacientes, pois os equipamentos eletromédicos precisam de cuidado especial durante todo o seu ciclo de vida. São equipamentos utilizados em uma classe de pessoas com baixo estado de saúde e muitos desses produtos entram em contato direto com tecidos e órgãos dos pacientes.

Com a obrigatoriedade do Gerenciamento de Risco, aumenta os requisitos regulatórios utilizados para a produção de equipamentos eletromédicos no país, ou seja, os produtos devem ser projetados e fabricados de forma que não comprometam o estado clínico e a segurança dos pacientes. Para tanto, os fabricantes precisarão descobrir os possíveis riscos potenciais e devem tentar reduzi-los a um grau compatível com a proteção à saúde.

O ponto negativo do Gerenciamento de Risco aplicado a equipamentos eletromédicos é que muita prescrição é subjetiva, ou seja, precisa-se fazer, mas não é dito como deve ser feito. Todo o desenvolvimento do processo fica a cargo do fabricante que deve ter o conhecimento amplo do seu produto para transformá-lo no mais seguro possível e, desta forma, atender os requisitos das Normas vigentes. Neste ponto entra a parte da competência, honestidade e sinceridade dos fabricantes.

\subsubsection{Conceitos Básicos de Gerenciamento de Risco conforme a Norma ANBT NBR ISO 14971:2009}

Para aqueles não muito familiarizados com o assunto, há uma grande confusão sobre os conceitos utilizados para a definição de risco, perigo e outros termos utilizados. Para poder aprofundar no assunto é de fundamental importância que o indivíduo responsável pelo processo de Gerenciamento de Risco tenha o conhecimento dos termos básicos. A seguir serão apresentados os principais termos 
utilizados na Norma NBR ISO 14971 e que também podem ser encontrados na Norma ABNT NBR IEC 60601-1:2010.

- Perigo: fonte potencial de dano.

- Dano: lesão física ou prejuízo à saúde da pessoa, ou prejuízo à propriedade ou ao meio ambiente.

- Situação Perigosa: circunstância em que a pessoa, propriedade ou meio ambiente estejam expostos a um ou mais perigo(s).

- Ciclo de vida: Todas as fases da vida de um produto para a saúde, desde a concepção inicial até a retirada de serviço e descarte.

- Evidência objetiva: dados que apoiam a existência ou veracidade de alguma coisa.

- Registro: documento que representa resultados obtidos ou fornece evidências de atividades realizadas.

- Risco: combinação da probabilidade de ocorrência de um dano e a severidade de tal dano.

- Risco residual: risco remanescente após os procedimentos de controle de risco ter sidos adotados.

- Análise de risco: utilização sistemática de informação disponível para identificar perigos e estimar riscos. A análise de risco inclui o exame das diferentes sequências de eventos que podem produzir situações perigosas e danos.

- Determinação de risco: processo completo composto pela análise e avaliação de risco.

- Controle de risco: processos por meio dos quais decisões são tomadas e procedimentos são implementados para a redução ou manutenção de riscos dentro de níveis especificados.

- Estimativa de risco: processo utilizado para designar valores à probabilidade de ocorrência do dano e a severidade de tal dano.

- Avaliação de risco: processo de comparação entre o risco estimado e um dado critério de risco para determinar a aceitabilidade de risco.

- Arquivo de gerenciamento de risco: conjunto de registro e outros documentos que são produzidos pelo gerenciamento de risco.

- Severidade: Medida das possíveis consequências de um perigo. 
- Modo de falha é o efeito pelo qual uma determinada falha é observada em um componente de sistema ${ }^{[18]}$.

A Figura 2.6 apresenta a relação entre perigo, sequência de eventos, situação perigosa e dano.

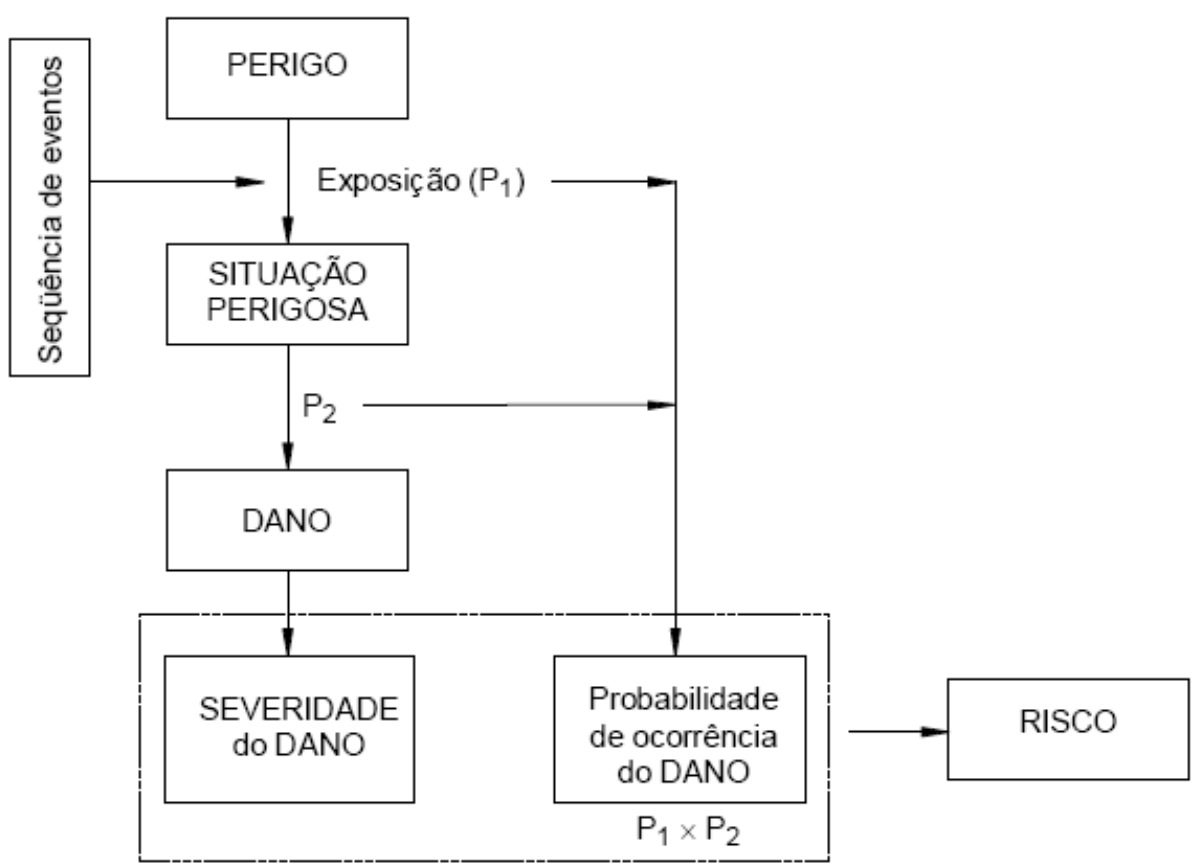

IEC 2430/05

NOTA $P_{1}$ é a probabilidade de ocorrência de uma SITUAÇÃO PERIGOSA.

$\mathrm{P}_{2}$ é a probabilidade de uma SITUAÇÃO PERIGOSA levar a um DANO.

Figura 2.6 - Representação Gráfica da relação entre perigo, situação perigosa e dano na determinação de risco.

Fonte: ABNT NBR ISO 14971:2009.

Conforme descrito pela Norma ABNT NBR ISO 14971:2009, um perigo não pode resultar em dano até que uma sequência de eventos ou outras circunstâncias (incluindo utilização normal) levem a uma situação perigosa. Como resultado do processo de Gerenciamento de Risco, a aceitabilidade de risco relacionada pode ser avaliada pela estimativa da severidade e da probabilidade de ocorrência do dano que pode resultar dessa situação perigosa. 


\subsubsection{Estrutura e Requisitos da Norma ABNT NBR ISO 14971:2009}

Os requisitos apresentados pela Norma ABNT NBR ISO 14971:2009 são aplicáveis a todos os estágios do ciclo de vida de um dispositivo médico. A estrutura desta Norma é composta por:

- Introdução:

Neste item o leitor se deparará com uma ideia geral da Norma, uma pequena explanação sobre a sua finalidade e os seus objetivos, bem como a definição de que Gerenciamento de Risco possui dois componentes, a probabilidade de ocorrer um dano e as consequências deste dano ou sua severidade/gravidade. Neste item a Norma também introduz a ideia que de cada fabricante tem uma percepção diferente de risco, ou seja, o que para um fabricante é um grau de risco menor, para outros podem ser algo mais preocupante e de alto risco, mas todas estas percepções dependem do conhecimento e da cultura das pessoas envolvidas com o processo de Gerenciamento de Risco em cada empresa. Também neste item a Norma faz algumas restrições quanto ao seu uso, como por exemplo, nela está escrito: "Esta Norma não se aplica a decisões clínicas" e "Esta Norma não especifica a aceitabilidade dos níveis de risco".

- Cláusula 2:

$\mathrm{Na}$ cláusula dois são apresentados os significados dos termos e definições utilizados no decorrer do texto da Norma. Neste item há também algumas notas e referências.

- Cláusula 3:

A cláusula 3 apresenta os requisitos gerais para Gerenciamento de Risco. Nesta cláusula há subdivisão para as seguintes subcláusulas:

Subcláusula 3.1- Processo de Gerenciamento de Risco.

Neste item a Norma prescreve que o fabricante deve manter um processo sempre em curso para identificação de riscos associados ao dispositivo médico, 
estimando, controlando e avaliando esses riscos associados e, principalmente, monitorando a efetividade dos controles empregados.

Subcláusula 3.2 Gerenciamento de Responsabilidades.

Neste item são discutidas as responsabilidades da alta administração da empresa perante 0 processo. A alta administração deve evidenciar comprometimento, assegurando o fornecimento adequado das informações e garantindo a tarefa do pessoal adequado para o Gerenciamento de Risco. Nesta subcláusula é descrito que a alta administração deve definir e documentar a política para o critério de determinação para aceitabilidade do risco garantindo que os critérios são baseados em Normas internacionais ou outro documento normativo nacional.

Subcláusula 3.3 Qualificação de Pessoal.

Nesta subcláusula é prescrito que todo o pessoal envolvido no Gerenciamento de Risco deve ter conhecimento e experiência apropriados para desempenhar as tarefas.

Subcláusula 3.4 Plano de Gerenciamento de Risco.

Nesta subcláusula é descrito que todas as atividades relacionadas ao Gerenciamento de Risco devem ser minuciosamente planejadas e documentadas.

Subcláusula 3.5 Arquivo de Gerenciamento de Risco.

Este item especifica que o fabricante deve estabelecer um arquivo de Gerenciamento de Risco. Este arquivo deve prover rastreabilidade para cada dano identificado e a análise de risco, avaliação de risco, implementação e verificação do controle das medidas de risco.

- Cláusula 4: Análise de Risco.

$\mathrm{Na}$ cláusula 4 é apresentado de fato como é feita a análise de risco e todo o processo dessa análise. 
Subcláusula 4.1 Processo de Análise de Risco.

A implantação das análises de risco planejadas e os resultados dessa implantação em cada dispositivo médico em particular devem ser arquivados em um documento de Gerenciamento de Risco. Este arquivo deve conter, além desses resultados, as seguintes especificações: uma descrição e identificação do dispositivo médico analisado, identificação da pessoa e da organização que realizaram as análises, o escopo e a data.

Subcláusula 4.2 Utilização destinada e identificação das características relacionadas à segurança do dispositivo médico.

Neste item são discutidos assuntos sobre a importância de o fabricante documentar a utilização destinada e a má utilização razoavelmente previsível do produto para a saúde, ou seja, documentar as características qualitativas e quantitativas que poderiam afetar a segurança do produto.

Subcláusula 4.3 Identificação de Perigos.

Neste item é prescrito que o fabricante deve ter uma lista de perigos conhecidos ou previsíveis associados ao produto para a saúde, tanto em condições normais quanto em condições de falha.

Subcláusula 4.4 Estimativa de risco para cada situação perigosa.

Neste item é prescrito que o fabricante deve registrar as situações perigosas resultantes das sequências ou combinações de eventos razoavelmente previsíveis que podem resultar em uma situação perigosa. Para cada situação perigosa os riscos associados devem ser estimados utilizando informações ou dados disponíveis.

- Cláusula 5 Avaliação de Risco.

Nesta cláusula é discutida a avaliação do risco para cada situação perigosa identificada.

- Cláusula 6 Controle de Risco.

Nesta cláusula são discutidos os procedimentos que o fabricante deve adotar para fazer o controle do risco. O fabricante deve identificar procedimentos de 
controle de risco que sejam apropriados para a redução dos riscos a um nível aceitável.

Subcláusula 6.2 Análise de opções de Controle de Risco.

O fabricante deve identificar procedimentos de controle de risco que sejam apropriados para a redução dos riscos a um nível aceitável. Se, durante a análise de opções o fabricante determinar que a redução do risco requerida é impraticável, ele deve conduzir uma análise de risco/benefício do risco residual.

Subcláusula 6.3 Implementação de Medidas de Controle de Risco.

O fabricante deve verificar a eficácia da(s) medida(s) de controle de risco e os resultados. A Norma prescreve que os resultados devem ser registrados no arquivo de gerenciamento de risco.

Subcláusula 6.4 Avaliação do Risco Residual.

Nesta subcláusula, após a aplicação dos procedimentos de controle de risco, qualquer risco residual deve ser avaliado pelo fabricante com base no critério definido no plano de gerenciamento de risco.

\section{Subcláusula 6.5 Análise Risco/Benefício.}

Se o risco residual não for julgado aceitável utilizando o critério estabelecido no plano de gerenciamento de risco e o controle adicional de risco não for viável, o fabricante pode colher e analisar criticamente dados e literatura para determinar se os benefícios médicos da utilização destinada superam o risco residual. Se essa evidência não apoiar a conclusão de que os benefícios médicos superam o risco residual, então o risco residual continua inaceitável. Sendo inaceitável, talvez não seja viável o desenvolvimento do produto até que se possa controlar o risco.

Subcláusula 6.6 Riscos originados de medidas de Controle de Risco.

Para esta subcláusula o fabricante deve avaliar os efeitos dos procedimentos de controle de risco em relação à introdução de novos perigos e situações perigosas, além de verificar se riscos estimados para situações perigosas previamente identificadas são afetados pela introdução dos procedimentos de controle de risco. 
O fabricante deve assegurar que os riscos de todas as situações perigosas identificadas foram avaliados.

- Cláusula 7 Avaliação da aceitabilidade de Risco residual geral.

Nesta cláusula é descrito como o fabricante deve prosseguir após a implementação e verificação de todos os procedimentos de controle de risco. O fabricante deve decidir se o risco residual geral é aceitável. Se o risco residual geral for inaceitável, o fabricante pode analisar criticamente os dados para determinar se os benefícios médicos superam o risco residual geral.

- Cláusula 8 Relatório de Gerenciamento de Risco.

Nesta cláusula é prescrito para o fabricante realizar uma análise crítica do processo de gerenciamento de risco garantindo que o plano de gerenciamento de risco foi implementado apropriadamente, o risco residual geral é aceitável e se há métodos apropriados para obter informação de produção e pós-produção.

- Cláusula 9 Informação de Produção e Pós-Produção

Nesta cláusula são descritos os deveres que o fabricante tem em relação à documentação e manutenção de um sistema para coletar e analisar informações sobre o produto para a saúde, ou produtos similares, nas fases de produção e pósprodução.

Os anexos desta Norma são muito instrutivos, auxiliando os projetistas e outros envolvidos no desenvolvimento do produto na aplicação do Gerenciamento de Risco, por exemplo, no anexo C há questões que podem ser utilizadas para identificar características do produto para a saúde que poderiam gerar impactos sobre a segurança. No anexo $\mathrm{E}$ há exemplo de perigos que podem ser aplicados a alguns equipamentos eletromédicos e, no anexo $G$, há algumas informações e indicações sobre técnicas de Gerenciamento de Risco. Muitos fabricantes adotam uma ou mais técnicas sugeridas pelo anexo $G$ da Norma ABNT NBR ISO 14971:2009. As sugestões são muito importantes, pois auxiliam no desenvolvimento e detalhamento de todo o processo. Algumas das técnicas são: Análise Preliminar de Perigos (PHA), Análise de Árvore de Falhas (FTA), Análise do Tipo e Efeito de Falha (FMEA), Estudos de Perigos e Operabilidade (HAZOP) e, por fim, Análise de 
Perigo e Pontos Críticos de Controle (HACCP). É importante lembrar que os anexos das Normas não são obrigatórios, possuem apenas o intuito de ensinar o usuário.

\subsubsection{Análise do Tipo e Efeito de Falha - FMEA}

A metodologia de Análise do Tipo e Efeito de Falha, conhecida como FMEA (do inglês Failure Mode and Effect Analysis), é uma ferramenta que busca, em princípio, evitar por meio da análise das falhas potenciais e criando propostas de ações de melhoria, que ocorram falhas no projeto do produto ou do processo [19] [20].

Sabe-se que a origem da FMEA não é bem definida, mas o método foi desenvolvido e documentado pela primeira vez pelo exército americano. Outros autores dizem que surgiu através de estudos feitos pela NASA (National Aeronautics and Space Administration), durante o desenvolvimento do projeto Apollo ${ }^{[20]}$.

Em 1978 a Ford foi a primeira empresa automotiva a utilizar a FMEA. Na década de 80 as empresas automotivas do grupo AIAG (Automotive Industry Action Group) incorporaram a FMEA por meio da QS-9000 (atual ISO QS 16949). Atualmente a FMEA é utilizada por um conjunto de indústrias de vários outros campos, como, por exemplo, as áreas de petroquímica, médica e alimentícia ${ }^{[21]}$.

O objetivo primordial da FMEA é prevenir problemas em processos ou produtos antes que os mesmos ocorram ou identificá-los numa fase em que os custos de alterações dos processos ou produtos sejam relativamente mais baixos ou viáveis $^{[22] ~[23] . ~}$

Apesar de ter sido desenvolvida com um enfoque no projeto de novos produtos e processos, a metodologia FMEA, pela sua grande utilidade, passou a ser aplicada de diversas maneiras. Assim atualmente é utilizada para diminuir as falhas de produtos e processos existentes e para diminuir a probabilidade de falha em processos administrativos $^{[19][20]}$.

O conceito relacionado à FMEA é a divisão de um sistema ou processo em partes e a posterior análise de cada uma destas partes. Neste conceito básico, e relativamente simples, reside à origem de várias críticas a esta metodologia para a área de Gerenciamento de Riscos. Em sistemas extremamente complexos, estas 
partes podem se combinar e interagir de formas nas quais as pessoas não são capazes de prever todas as possíveis possibilidades de falhas. Apesar deste caráter "reducionista" para alguns, certamente há espaço para esta metodologia na área de Gerenciamento de Riscos, mas como em toda e qualquer atividade de grande importância, deve haver um conhecimento cultural tanto na metodologia FMEA como no processo de Gerenciamento de Risco ${ }^{[19][23]}$.

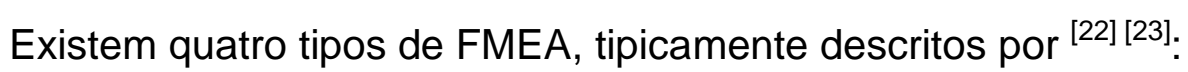

- FMEA de Sistema: usada para analisar sistemas e subsistemas no início do conceito e do projeto. Uma FMEA de sistema foca nos modos de falhas potenciais, causados por deficiência do sistema ou das funções do sistema. Nas análises são incluídas interações entre sistemas e entre elementos de um subsistema.

- FMEA de produto: usada para analisar produtos antes de sua liberação para a fabricação. O foco é em modos de falha causados por deficiências de projeto de produto.

- FMEA de processo: utilizada para analisar processos de fabricação e montagem. O foco é em modos de falha causados por deficiência de processo de fabricação ou montagem.

- FMEA de serviço: usada para analisar serviços antes de chegarem ao consumidor. Foca em todos os modos de falha (tarefas, erros, enganos) causados por deficiência do sistema ou do processo.

\subsubsection{Processo de Aplicação}

Para a aplicação da metodologia FMEA, o princípio utilizado é o mesmo para qualquer um dos tipos descritos anteriormente, seja FMEA de produto, processo, serviço ou se é aplicado para produtos/processos novos ou já em operação. A análise consiste na formação de um grupo de pessoas que identificam para o produto/processo em questão, suas funções, os tipos de falhas que podem ocorrer, os efeitos e as possíveis causas dessas falhas. Em seguida são avaliados os riscos de cada causa de falha por meio de índices e, com base nesta avaliação, são 
tomadas as ações necessárias para diminuir estes riscos, aumentando a confiabilidade do produto/processo ${ }^{[19]}$.

Em uma sessão de FMEA o fluxo de trabalho é orientado por um formulário padrão (Figura 2.7) que deve ser preenchido pelo grupo, obedecendo aos critérios de clareza e objetividade.

Um formulário de FMEA possui a seguinte característica: a primeira coluna é reservada à descrição do processo, onde se deve identificar a etapa do processo de produto em questão. Em seguida tem-se o item função, onde devem ser identificadas quais características do produto precisam ser atingidas. As próximas colunas referem-se à identificação dos tipos de falha, seus efeitos e causas. Segue para a avaliação dos riscos (severidade do efeito, probabilidade de ocorrência e detecção da causa ou de seu modo). As últimas colunas são reservadas para a proposição de ações de redução de risco e registro de resultados. É importante ressaltar que um componente pode ter uma ou mais funções e normalmente vários modos de falha. Por sua vez, cada modo de falha pode possuir diversos efeitos e causas $^{[20][21][23]}$.

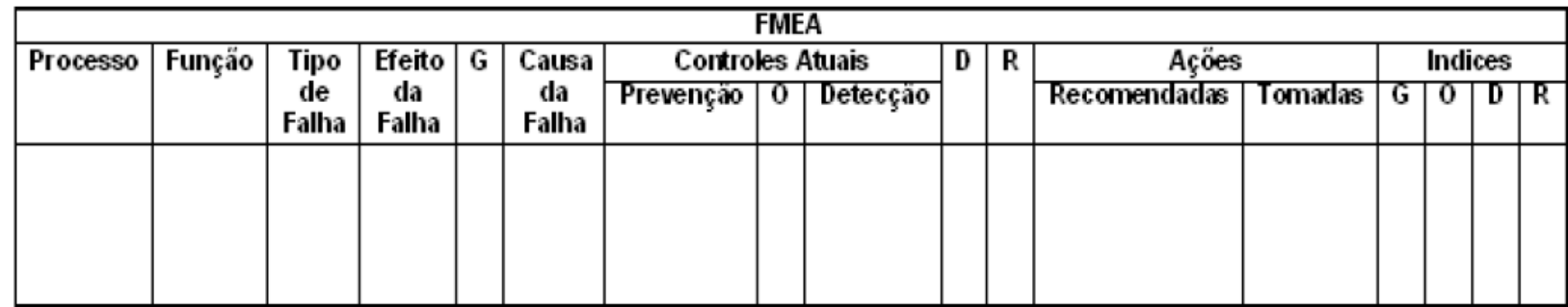

Figura 2.7 - Exemplo de Formulário de FMEA

Fonte: Ribeiro, K.S (2009)

onde:

- G (Gravidade): este campo é tabelado por Normas sobre FMEA e indica o grau de severidade.

- O (Ocorrência): este campo é preenchido a partir de valores tabelados e indica a probabilidade da causa ocorrer.

- D (Detecção): campo preenchido a partir de valores tabelados e indica quão eficaz é o método de detecção.

- $R$ (Resultado): o resultado é obtido a partir do produto entre os índices $\mathrm{G}, \mathrm{O}$ e D. 
A metodologia FMEA é importante porque pode proporcionar ${ }^{[19]}$ :

- Uma forma sistemática de se catalogar informações sobre as falhas dos produtos/processos;

- Melhor conhecimento dos problemas nos produtos/processos;

- Ações de melhoria no projeto do produto/processo, baseadas em dados e devidamente monitoradas (melhoria contínua);

- Diminuição de custos, por meio da prevenção de ocorrência de falhas;

- O benefício de incorporar dentro da organização a atitude de prevenção de falhas;

- Atitude de cooperação e trabalho em equipe, além da preocupação com a satisfação dos clientes.

\subsubsection{Etapas para a Aplicação}

Uma sessão se inicia com identificação de funções e requisitos de um sistema, subsistema, componente ou etapa de uma fase da fabricação, conforme o tipo de FMEA.

$\mathrm{Na}$ etapa seguinte são determinados todos os modos de falhas concebíveis. Essa etapa é fundamental, pois cada modo de falha não descoberto pode levar a perigosos efeitos de falha e, portanto, a drásticos problemas de confiabilidade.

Os modos de falhas podem ser identificados de diversas maneiras ${ }^{[22]}{ }^{[23]}$ :

- Estatística de Falha

Esta deve ser a primeira opção a ser usada na metodologia FMEA. Importante registrar no formulário do FMEA os modos de falha que apareceram em casos semelhantes para se evitar problemas recorrentes;

- Experiência dos participantes da sessão de FMEA

Após serem esgotadas as falhas conhecidas, com a ajuda da experiência dos membros da equipe de FMEA são derivados modos de falhas principais; 
- Checklists

Listas de possíveis falhas são frequentemente usadas;

- Brainstorming

A utilização de meios criativos para descobrir todos os modos de falha em casos particulares de alto perigo.

O próximo passo é determinar os efeitos e causas do modo de falha e avaliar os riscos. É avaliada a severidade do efeito da falha (índice $\mathrm{G}$ ), a probabilidade de ocorrência da causa de falha (índice $\mathrm{O}$ ), e a probabilidade de detecção da causa da falha ou de seu modo (índice D). Na avaliação da severidade, se as pessoas são expostas a perigos, o índice de severidade recebe um valor alto; por outro lado, se o efeito for apenas diminuição de conforto, é atribuído um baixo valor. A avaliação da ocorrência refere-se a uma falha hipotética (potencial) ou que já vem ocorrendo no campo. $O$ índice $D$ determina o sucesso na detecção (antes de chegar ao cliente) da causa da falha ou de seu modo. A multiplicação dos três índices (GxOxD) resulta no índice R (Risco) ou (RPN- Risk Priority Number) ${ }^{[20][21]}$.

Conforme apresentado anteriormente, para a utilização do formulário FMEA é preciso utilizar valores tabelados dos índices $\mathrm{G}, \mathrm{O}$ e D. A definição de índice de gravidade, que também é conhecido como índice de severidade, está associado, em uma relação crescente, aos efeitos das falhas sobre a manufatura e sobre o cliente. O índice de gravidade/severidade só poderá ser reduzido através de uma alteração no projeto.

A definição do índice de ocorrência acontece pela probabilidade de uma causa acontecer durante o processo ou no produto.

O índice de detecção indica se a forma de controle é capaz de detectar erros no processo ou no produto ${ }^{[20]}$.

Cada Norma de aplicação da FMEA possui escalas padrão para a atribuição dos valores para estes índices. As escalas são normalmente de números inteiros de 1 a 10. O valor 1 representa gravidade/severidade mínima, baixa ocorrência e detecção muito provável. O valor 10 representa uma avaliação extremamente negativa e baixa confiabilidade do produto. Algumas Normas conhecidas utilizadas para a aplicação da FMEA são a ISO/TS 16949 e a IEC 60812 [13] [22]. 


\subsubsection{Análise da Árvore de Falha - FTA}

A FTA do inglês Fault Tree Analysis é uma técnica utilizada no estudo de falhas potenciais de um sistema. É uma análise dedutiva detalhada, uma representação gráfica de relações lógicas entre eventos de falha ${ }^{[26]}$.

A FTA estuda o desenvolvimento de uma falha particular do sistema (efeito), denominada de evento de topo, e as falhas básicas (causas), denominadas de eventos primários. Um exemplo para simplificar a ideia da FTA seria tentar descobrir um crime a partir das evidências obtidas. Por possuir esta característica, a FTA possui uma abordagem top-down ${ }^{[21][24]}$ (ver Figura 2.8).

Para se determinar o comportamento da falha de um sistema e/ou de elementos do sistema juntamente com suas conexões, o evento indesejado do sistema (evento topo) é primeiramente definido. No próximo passo são analisadas possíveis falhas do próximo nível inferior e como poderiam ser correlacionadas com a falha superior. O nível mais baixo (down) corresponde aos possíveis modos de falha $^{[21][24] \text {. }}$.

$\mathrm{Na}$ realização da FTA são utilizados símbolos lógicos padronizados, comumente encontrado em fluxogramas para representar uma sequência de enventos (ver Figura 2.9).

Resultado indesejado, falha do sistema

(TOP)

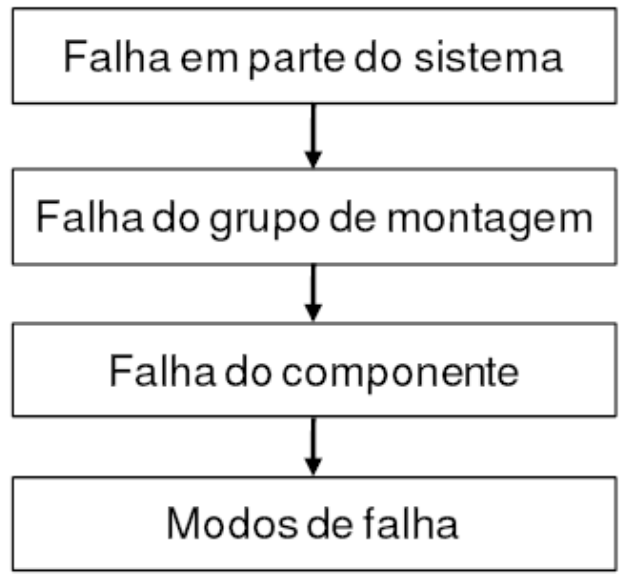

Característica do componente, problema no projeto

(DOWN)

Figura 2.8 - Procedimento para a estruturação de uma árvore de falha Fonte: Laurenti, R. (2010). 


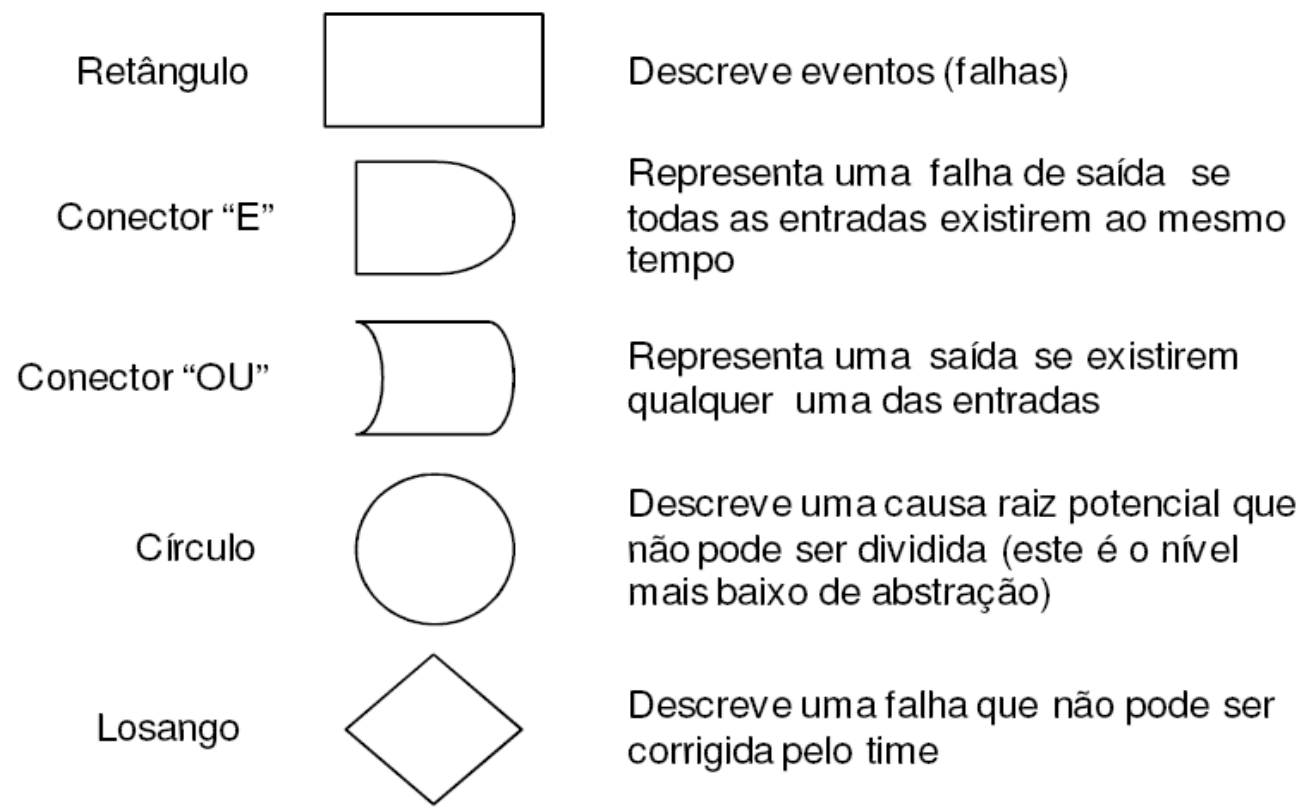

Figura 2.9 - Símbolos lógicos da FTA

Fonte: Laurenti, R. (2010).

\subsubsection{Estudo de Perigo e Operabilidade - HAZOP}

A HAZOP do inglês Hazard Operability Analysis foi originalmente desenvolvida para o uso na indústria de processos químicos, mas, embora esta técnica foque nos desvios das intenções de projeto, existem alternativas para projetistas de produtos para a saúde. Uma metodologia HAZOP pode ser aplicada ao funcionamento e/ou operação de um produto para a saúde, por exemplo, aos métodos e/ou processos existentes usados para o diagnóstico, tratamento ou alívio de doença. Outra aplicação seria a um processo utilizado na fabricação ou na manutenção e/ou serviço do produto para a saúde, por exemplo, esterilização, que pode ter impacto significativo ${ }^{[13]}[25]$.

A HAZOP é baseada em uma teoria que assume que os acidentes são causados por desvios do projeto ou das intenções do funcionamento. É uma técnica sistemática para identificar perigos e problemas de operabilidade. Assim como a FMEA, utiliza uma equipe de pessoas com experiência no projeto e aplicação. 
Existem dois tipos de membros da equipe, aqueles que trarão uma contribuição técnica e aqueles que terão um papel de apoio e estruturação. A composição ideal da equipe seria entre 3 a 6 membros técnicos ${ }^{[13][25]}$.

Uma vez que as sessões são altamente estruturadas e muito sistemáticas, é necessário ter um líder de estudo. O líder de estudo guia o questionamento sistemático e ele deve estar amplamente treinado. Se possível, o líder não deve estar associado ou envolvido com o objetivo do estudo, uma vez que ocorreria o perigo de produzir pontos viciados e falhar no uso sistemático da técnica, mas ele deve ter conhecimento técnico suficiente para ser capaz de entender e controlar as discussões da equipe ${ }^{[13][27]}$.

\subsubsection{Aplicação da HAZOP}

O procedimento de estudo toma uma descrição total do processo e questiona sistematicamente cada parte dele para descobrir como eventuais desvios das intenções de projeto ou de operação poderiam ocorrer, decidindo se esses desvios podem constituir em perigos.

O questionamento enfoca, por etapas, todas as partes da instalação ou manobras de operação. Cada parte é submetida a um número de questões, formuladas em torno de algumas palavras-guia, que são derivadas das técnicas do método.

As palavras-guia são um conjunto de termos padrão que podem ser aplicados aos parâmetros de processos para gerar desvios imaginários (ver Tabela 2.4). Seu valor e aplicabilidade dependem das intenções para as quais as mesmas são aplicadas e os possíveis modos de desvio destas intenções. 
Tabela 2.4 - Parâmetros de Processo e Palavras-guia mais utilizadas.

Fonte: Pascon. P.E(2009)

\begin{tabular}{|c|c|}
\hline Parâmetro de Processo & Palavras-guia \\
\hline Fluxo & Mais \\
\hline Pressão & Menos \\
\hline Temperatura & Nenhum (a) \\
\hline Agitação & Reverso/Oposto \\
\hline Nível & Antes \\
\hline Utilidades & Depois \\
\hline Substância & Outro que \\
\hline
\end{tabular}

O relatório final com os resultados obtidos durantes as sessões de HAZOP deve conter:

- Uma planilha de trabalho gerada pela equipe durante as sessões de estudo;

- Uma cópia dos documentos de referência (fluxogramas, instruções, índice de linhas, folhas de dados) usados durantes as sessões e marcados pelo líder para o efeito de construção e execução.

Este relatório deve fazer parte do arquivo da empresa.

O sucesso ou falha desta técnica dependerá de quatro aspectos:

- Precisão dos documentos de engenharia e outros dados usados como base para o produto;

- Habilidades técnicas e visão do grupo;

- Habilidade do grupo em usar a abordagem como uma ajuda a sua imaginação em visualizar desvios, causas eventos e consequências;

- Habilidade do grupo em manter um senso de proporção, particularmente quando analisando a seriedade dos desvios ou perigos quando identificados $^{[25]}$. 


\subsubsection{Comparação entre as Metodologias FMEA, FTA e HAZOP.}

A FTA estuda o desenvolvimento de uma falha particular do sistema (efeito), ou falha topo, e as básicas (causas), ou eventos primários, e difere da FMEA basicamente em três aspectos ${ }^{[24] ~[26]: ~}$

- A FTA estuda aqueles resultados negativos considerados suficientemente sérios para demandar uma análise posterior. A FMEA tentar acessar a confiabilidade de cada componente, separadamente.

- O ponto de partida da FTA é uma lista dos modos de falha para os quais se deseja dar algumas soluções. A FMEA começa com a identificação dos componenentes e, para cada um deles, indica modos de falha, efeitos e possiveis causas;

- Por ser um modelo gráfico construido de maneira lógica, a FTA permite a análise conjunta de várias causas que levarão à ocorrência do efeito topo, proporcionando um maior entendimento do comportamento do produto ou processo. Diferentemente, a FMEA analisa cada causa de um modo de falha e seu efeito separadamente.

A diferença principal é que a FMEA é um método indutivo e a FTA é um método dedutivo ${ }^{[21]}$. A indução constitui na racionalização de casos individuais para uma conclusão geral. Já a dedução constitui na racionalização do geral para o específico.

Resumidamente, a FMEA é aplicada para se determinar quais falhas no sistema são possíveis e o método FTA é aplicado para se determinar como uma dada falha no sistema pode ocorrer ${ }^{[21]}$.

A metodologia Hazop pode ser considerada com um procedimento indutivo, no qual o grupo analisa um processo, gerando de uma maneira sistemática, perguntas para analisá-lo. As perguntas são baseadas pelas palavras-guia e surgem conforme a interação da equipe. Esta técnica consiste em uma busca estruturada das causas de possíveis desvios (perigo), por exemplo, na pressão, na temperatura, vazão ao qual pode ocorrer durante a utilização de um determinado produto. Para facilitar a compreensão, a execução da Hazop pode ser sintetizada da seguinte maneira: divisão do produto em partes e subpartes, em seguida é escolhida uma 
determinada subparte para ser analisada e, finalmente, aplicando as palavras-guia, verifica-se quais os desvios possíveis de acontecer. Para cada desvio é preciso investigar as causas possíveis de provocá-lo. Uma vez analisados todos os desvios, é escolhida outra subparte e assim sucessivamente, até ser investigado detalhadamente todo o produto ${ }^{[25]}$.

\subsection{AS NORMAS COLATERAIS DA SÉRIE 60601}

Como escrito anteriormente no item 2.3, as Normas Colaterais prescrevem ensaios para um subgrupo de equipamentos eletromédicos ou uma característica específica de todos os equipamentos eletromédicos não totalmente abordada pela Norma Geral, por exemplo, compatibilidade eletromagnética e sistemas de alarmes.

As Normas Colaterais atualmente em vigor no Brasil complementam as prescrições dos itens da edição de 1997 da Norma Geral com a mesma sequência. Por exemplo, o item seis das Normas Colaterais e Norma Geral de 1997 correspondem à documentação, o item sete à potência de entrada e assim sucessivamente. É importante destacar que a edição de 2010 da Norma Geral possui numeração e sequência dos ensaios diferentes.

As Normas Colaterais atualmente utilizadas para ensaiar equipamentos eletromédicos podem ser observadas na Tabela 2.3. Algumas Normas Colaterais já se encontram disponíveis para a compra no sítio da ABNT, mas elas ainda não foram incorporadas à série de Normas utilizadas atualmente no Sistema Brasileiro de Certificação. Essas Normas Colaterais são ABNT NBR IEC 60601-1-6:2011Usabilidade, ABNT NBR IEC 60601-1-8:2010 - Sistema de Alarme para Equipamento Eletromédico e Sistemas Eletromédicos, ABNT NBR IEC 60601-1-9 Prescrições básicas para um projeto Ecorresponsável e ABNT NBR IEC 60601-1-10 - Requisitos para o desenvolvimento de controladores fisiológicos em malha fechada. Atualmente existem demais Normas Colaterais disponíveis somente no sitio da IEC, por exemplo, a IEC 60601-1-11 - Requirements for medical electrical equipment and medical electrical systems used in the home healthcare environment. 


\subsection{A NORMA IEC 60601-2-24}

O FDIS (Projeto de Norma desenvolvido por um determinado Comitê normativo da IEC ou ISO, mas ainda não publicado como Norma) da Norma Particular IEC 60601-2-24 - Requirements for basic safety and essential performance of infusion pumps and controllers traz prescrições importantes de segurança e desempenho essencial a serem verificadas em bombas de infusão e controladores como, por exemplo, informações referentes à exatidão de dados e controles, medição da pressão da oclusão, medição do volume de bolus, alarmes e, na edição de 2011, prescrições para Gerenciamento de Risco ${ }^{[28]}$.

Um fator importante é conhecer o funcionamento e a operação dos equipamentos, porque para a realização de alguns ensaios, como por exemplo, o ensaio de exatidão de dados, há a necessidade de realizá-lo de acordo com o tipo de bomba de infusão e o equipamento deve ser operado conforme as informações declaradas pelo fabricante ${ }^{[7]}$.

A Bomba de infusão é "um equipamento destinado a regular o fluxo de líquidos administrados ao paciente sob pressão positiva gerada pela bomba" (ABNT NBR IEC 60601-2-24:1999, p. 4) e (IEC 60601-2-24:2011, p. 10). A Figura 2.10 apresenta alguns exemplos de Bombas de Infusão e a Figura 2.11 um exemplo de equipo comercial de uma bomba de infusão.
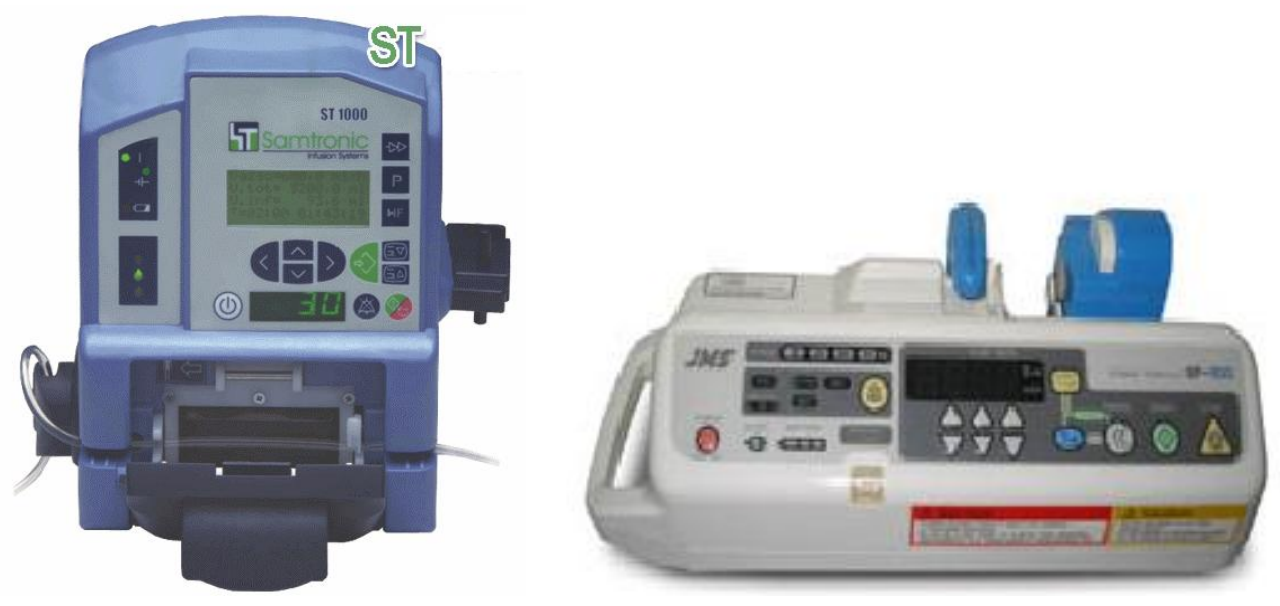

Figura 2.10 - Bombas de Infusão

Fonte: Rosa, D. A. O (2007) 


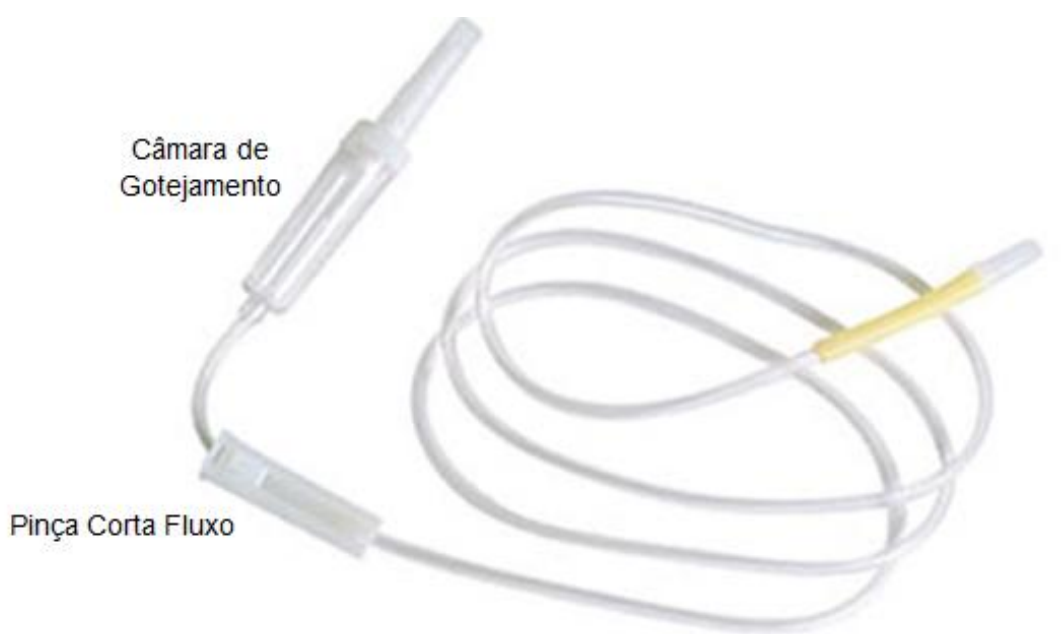

Figura 2.11 - Equipo para uma bomba de infusão

Fonte: Rosa, D. A. O (2007)

O FDIS de 2011 da IEC 60601-2-24 possui a mesma sequência dos itens de ensaios da edição de 2010 da Norma Geral, complementando-os ou em algumas seções quando não há prescrições, pede-se para aplicar o ensaio da Norma Geral.

Um item que é igualmente ensaiado e possui grande destaque nas duas edições da Norma 60601-2-24 ${ }^{[28]}[29]$, é o de exatidão de dados e controle. Este ensaio é de fundamental importância para bombas de infusão e controladores, pois há necessidade de verificar se o equipamento mantém a exatidão da infusão declarada pelo fabricante.

\subsubsection{Ensaio de Exatidão de Dados e Controle}

Este ensaio é realizado conforme o tipo definido do equipamento eletromédico e conforme especificado nos subitens 201.12.1.102 a 201.12.1.108 da Norma IEC 60601-2-24, que prescrevem a necessidade de adquirir dados sobre a infusão do equipamento sob ensaio e o tratamento desses dados, gerando-se gráficos que auxiliam na compreensão e análise dos resultados.

A montagem do arranjo baseia-se na Figura 2.12 para bombas de infusão volumétrica e controladores e na Figura 2.13 para bombas de seringa. 


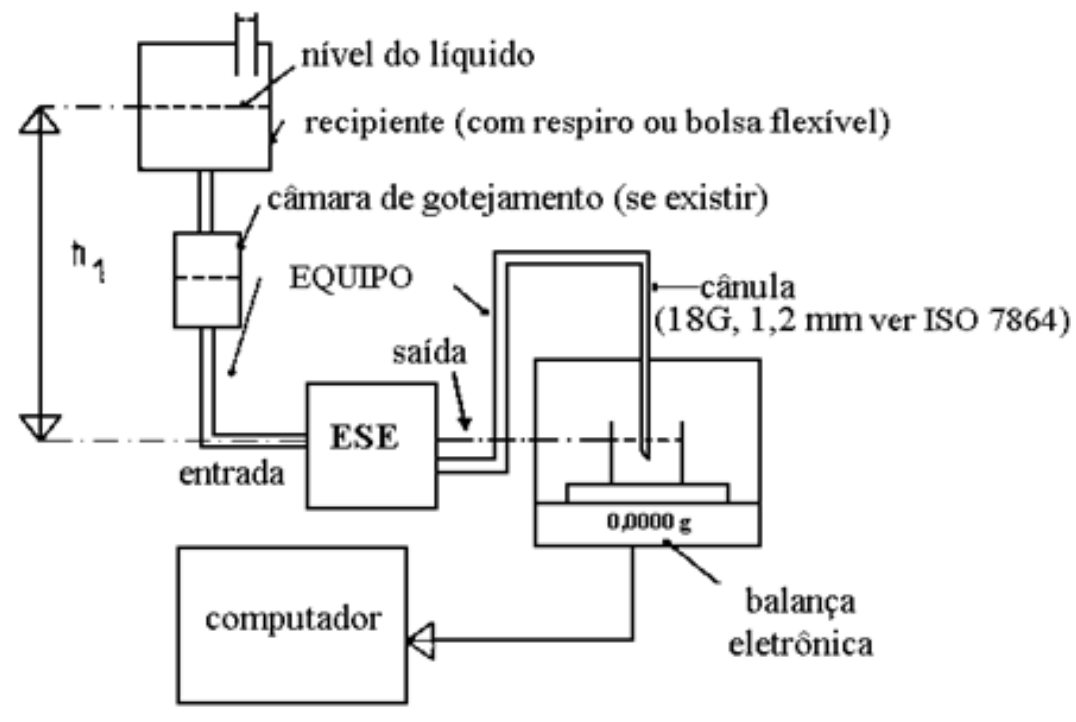

Figura 2.12 - Arranjo para ensaio de Bombas de Infusão Volumétrica e Controladores. Figura 201.104a da Norma IEC 60601-2-24.

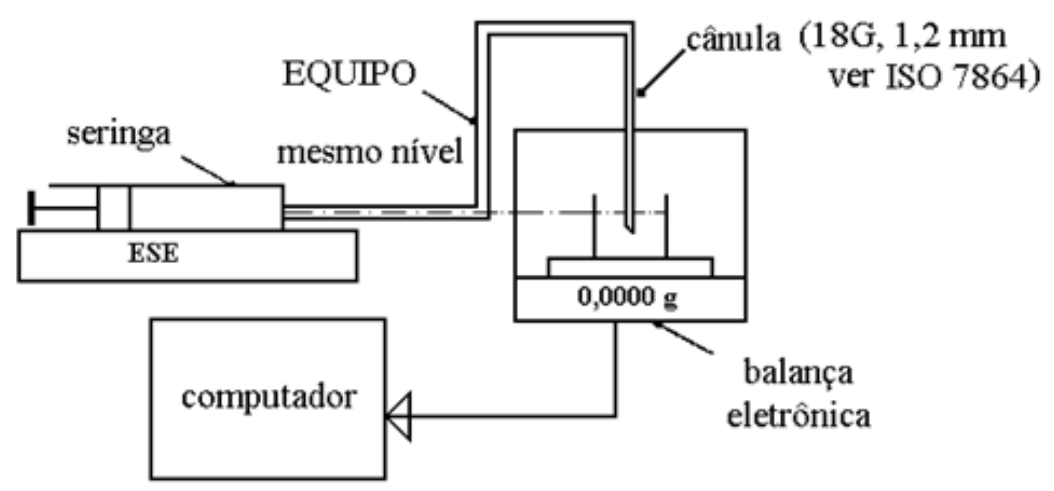

Figura 2.13 - Arranjo para ensaio de Bombas de Seringa.

Figura 201.104b da Norma IEC 60601-2-24.

A duração do ensaio é determinada através do tempo de substituição do equipo recomendado nos documentos acompanhantes do equipamento eletromédico (denominado como tempo $\mathrm{T}$ ). A altura $\mathrm{h}$ para a montagem do arranjo da Figura 2.12 é ajustada conforme especificado pelo fabricante. A vazão selecionada para ensaio deve estar de acordo com a Tabela 2.5. 
Tabela 2.5 - Vazões estabelecidas e volumes de BOLUS (Tabela 201.102 adaptada da Norma IEC 60601-2-24)

\begin{tabular}{|c|c|c|c|c|}
\hline \multirow[b]{2}{*}{ EQUIPAMENTO } & \multicolumn{2}{|c|}{ Vazões estabelecidas } & \multicolumn{2}{|c|}{ Bolus } \\
\hline & Mínima & Intermediária & Mínimo & Máximo \\
\hline $\begin{array}{l}\text { CONTROLADORES DE } \\
\text { INFUSÃO GOTA-A-GOTA }\end{array}$ & $\mathrm{x}$ & $\mathrm{x}$ & & \\
\hline $\begin{array}{l}\text { BOMBAS DE INFUSÃO } \\
\text { GOTA-A-GOTA }\end{array}$ & $\mathrm{x}$ & $\mathbf{x}$ & & \\
\hline $\begin{array}{l}\text { CONTROLADORES DE } \\
\text { INFUSÃO VOLUMÉTRICA }\end{array}$ & $\mathrm{x}$ & $\mathbf{x}$ & & \\
\hline $\begin{array}{l}\text { BOMBAS DE INFUSÃO } \\
\text { VOLUMÉTRICA }\end{array}$ & $x$ & $\mathbf{x}$ & $x$ & $x$ \\
\hline BOMBAS DE SERINGA. & $x$ & $x$ & $x$ & $x$ \\
\hline \multicolumn{5}{|l|}{$\begin{array}{l}\text { BOMBAS DE INFUSÃO } \\
\text { PARA UTILIZAÇÃO } \\
\text { AMBULATORIAL }\end{array}$} \\
\hline Tipo 1 & $x$ & $x$ & & \\
\hline Tipo 2 & & $x$ & & \\
\hline
\end{tabular}

A Norma IEC 60601-2-24 também prescreve que para a realização do ensaio é necessário: solução de ensaio (água para utilização médica) e uma agulha de 18 $\mathrm{G}(1,2 \mathrm{~mm}$ de diâmetro e $40 \mathrm{~mm}$ de comprimento).

Após o tempo de ensaio $\mathrm{T}$ ter decorrido, o ensaio deve ser repetido nas seguintes condições:

- Para Bombas de Infusão Volumétrica e Bombas de Seringa o ensaio deve ser repetido por um T de 2 horas na vazão intermediária $(5 \mathrm{ml} / \mathrm{h}$ para Bombas de Seringa e $25 \mathrm{ml} / \mathrm{h}$ para Bombas e Controladores de Infusão) e nas seguintes condições: sem contrapressão, com pressão positiva de $+100 \mathrm{mmHg}$ e com pressão negativa de $-100 \mathrm{mmHg}$.

- Somente para Bombas de Infusão Volumétrica o ensaio deve ser repetido por um período T de 2 horas com o reservatório de medicamento posicionado 0,5 m abaixo do mecanismo da bomba de infusão, sem contrapressão adicional.

É importante destacar que as escolhas desses materiais e condições são justificadas pela Norma IEC 60601-2-24 em seus anexos. Para a utilização da contrapressão e da agulha $18 \mathrm{G}$, por exemplo, são apresentadas as seguintes justificativas: 
- Como podem ser utilizados medicamentos de diferentes viscosidades durante o tratamento, o ensaio com contrapressão substitui a repetição dos ensaios utilizando-se líquidos de viscosidade diferente;

- A justificativa para utilização da agulha $18 \mathrm{G}$ é a de que este objeto não produz contrapressão adicional em qualquer tipo de vazão.

\section{- Gráfico de Partida e Curva de Trombeta}

Para a geração dos gráficos de partida são utilizadas algumas fórmulas descritas na Norma IEC 60601-2-24. Utilizando-se a eq. (1) e conhecendo-se a densidade do líquido, é possível calcular a vazão e gerar o gráfico de partida (ver Figura 2.14).

$$
Q=\frac{60\left(W_{i}-W_{i-1}\right)}{S d}[m I / h]
$$

onde:

$i=1,2 \ldots$

Wi: é a i-ésima amostra de massa no tempo de análise $T_{0}$ (corrigida por perdas por evaporação) em gramas;

$T_{0}$ : é o tempo de análise em min;

$S$ : é o intervalo da amostragem em min;

$d$ : é a densidade da água $\left(0,998 \mathrm{~g} / \mathrm{ml}\right.$ a $\left.23^{\circ} \mathrm{C}\right)$.

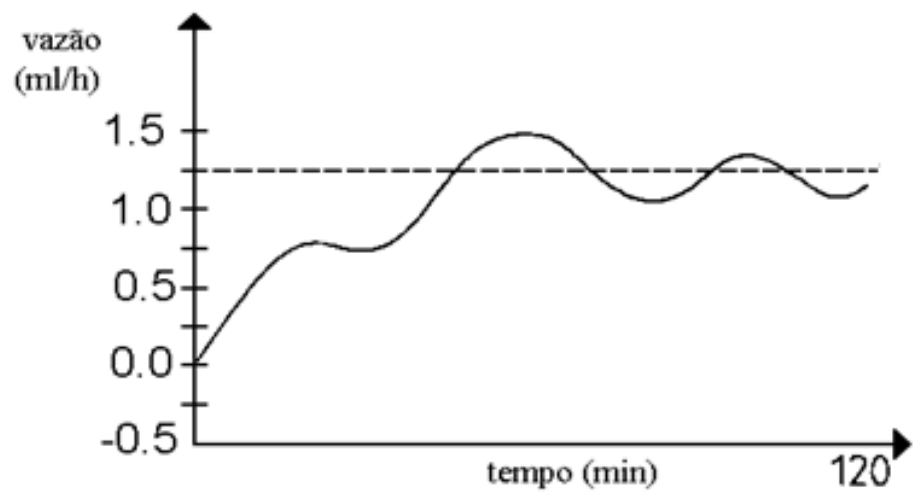

Figura 2.14 - Gráfico de partida (Figura 201.105 da Norma IEC 60601-2-24) 
A análise do gráfico de partida possibilita que o operador verifique a estabilidade da vazão nas duas primeiras horas do ensaio. A linha tracejada indica a vazão escolhida, o incremento da escala deve ser 0,2 vez a vazão escolhida, e o tempo 120 minutos indica as duas primeiras horas de ensaio.

Para geração da curva de trombeta (Figura 2.15) são utilizadas as eq. (2), (3), (4) e (5).

$$
\begin{gathered}
E p(\text { máx })=M_{j=1}^{m} \cdot\left[\frac{S}{P} x \sum_{i=j}^{j+\frac{P}{S}-1} 100 x\left(\frac{Q i-r}{r}\right)\right][\%] \\
E p(\text { min })=M_{j=1}^{m} \cdot\left[\frac{S}{P} x \sum_{i=j}^{j+\frac{P}{S}-1} 100 x\left(\frac{Q i-r}{r}\right)\right][\%] \\
A=\frac{100(Q-r)}{r}[\%] \\
B=\frac{100(Q-r)}{r}[\%]
\end{gathered}
$$

onde:

m: Quantidade de janela de observação.

Q: Fluxo volumétrico, em $\mathrm{ml} / \mathrm{h}$

$r$ : vazão desejada, em $\mathrm{ml} / \mathrm{h}$

$S:$ intervalo de amostragem, em min

$P$ : duração da janela de observação $(2,5,11,19$ e 31 min).

$j: 1,2 \ldots, \mathrm{m}$.

A: porcentagem do erro global médio da vazão medido no intervalo de tempo de análise $\mathrm{T} 1$.

T1: Segunda hora do tempo e ensaio.

$B$ : porcentagem do erro global médio da vazão medido no intervalo de tempo de análise T2.

T2: Última hora do tempo de ensaio.

Ep (max): erro máximo medido da janela de observação de duração específica. 
Ep (min): erro mínimo medido na janela de observação de duração específica.

Nas equações 4 e 5 , quando o ensaio é realizado na vazão intermediária com uma duração de 2 horas, T1 é igual a T2 e, portanto A será igual a B. Nos ensaios de vazão mínima, ou seja, devendo ser realizados em 24,48 ou 50 horas, T1 será diferente de T2 e, portanto A será diferente de B.

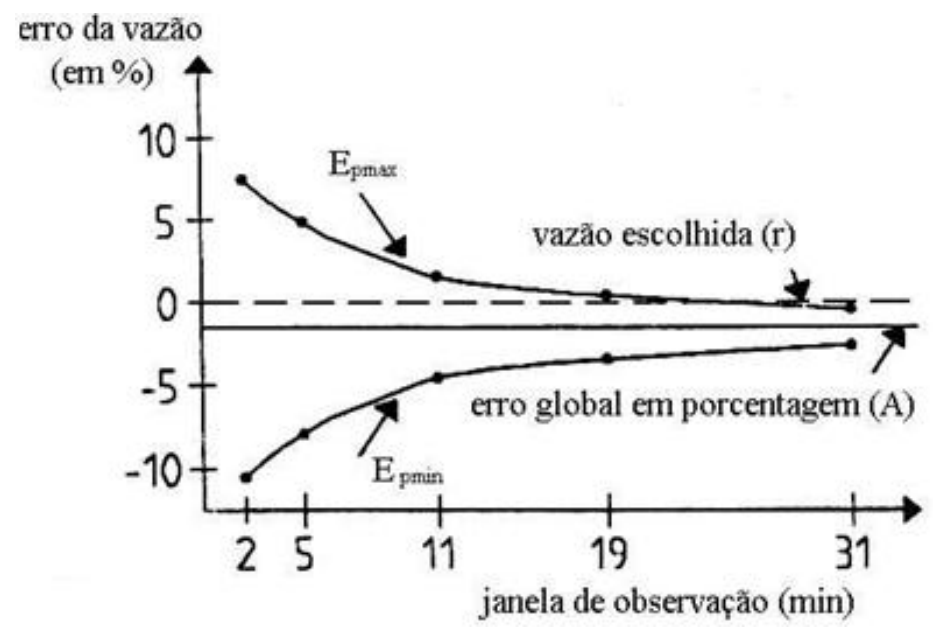

Figura 2.15 - Curva de trombeta (Figura 201.106 da Norma IEC 60601-2-24).

Os ensaios com duração superior a 2 horas são plotados os gráficos de trombeta da segunda hora do ensaio, designado como $\mathrm{T} 1$, e a última hora do período de ensaio designado como T2.

Tanto para a geração do gráfico de partida quanto para a curva de trombeta são capturados dois dados por minutos, ou seja, em 2 horas de ensaio são armazenados 240 dados e em 24 horas 2880 dados.

Um equipamento eletromédico que possua uma Norma Particular, como o exemplo do ensaio descrito anteriormente da Bomba de Infusão, além de ser ensaiado por sua Norma Particular, também será ensaiado pelos requisitos da nova Norma Geral, ou seja, será feita uma análise completa tanto verificando a exatidão dos dados como os riscos e a maneira como foi feito o Gerenciamento de Risco pelo fabricante. 


\subsubsection{Ensaios de Bombas de Infusão na DEC-LEB/EPUSP}

Os ensaios em bombas de infusão são muito frequentemente realizados na DEC-LEB/EPUSP, com a edição da Norma ABNT NBR IEC 60601-2-24:1999. A Tabela 2.6 apresenta a quantidade de bombas de infusão ensaiadas neste laboratório nos últimos cinco anos.

Tabela 2.6 - Bombas de Infusão ensaiadas na DEC-LEB/EPUSP nos últimos cinco anos. Fonte: DEC-LEB/EPUSP (2011)

\begin{tabular}{|c|c|}
\hline $\begin{array}{c}\text { Quantidade de Bombas de Infusão ensaiadas na } \\
\text { DEC-LEB/EPUSP }\end{array}$ & Ano dos Ensaios \\
\hline 7 equipamentos & 2007 \\
\hline 9 equipamentos & 2008 \\
\hline 4 equipamentos & 2009 \\
\hline 3 equipamentos & 2010 \\
\hline 6 equipamentos & 2011 \\
\hline
\end{tabular}

Com a análise desses dados e com a grande demanda por ensaios neste tipo de equipamento eletromédico, observou-se a necessidade de atualização dos procedimentos para bombas de infusão e controladores, ou seja, implantar o processo de Gerenciamento de Risco. Com as publicações de outras Normas Particulares, o processo também se repetirá a outros equipamentos eletromédicos, baseando-se nos mesmos critérios aplicados a Norma Geral de 2010 e à Norma Particular IEC 60601-2-24. 


\section{MATERIAIS E MÉTODOS PARA A EXECUÇÃO DA PESQUISA}

A metodologia adotada para aplicar o Gerenciamento de Risco em procedimentos de ensaios consistiu em um conjunto de pesquisas fundamentadas no estudo e interpretação dos textos técnicos normativos que prescrevem as novas diretrizes dos ensaios da Norma Geral, baseada na Norma ABNT NBR ISO 14971:2009 de Gerenciamento de Risco, conjunto de Normas Colaterais e a Norma Particular IEC 60601-2-24.

Após a avaliação realizada nos textos normativos foram realizadas as seguintes atividades:

1. Consulta e avaliação de arquivos de Gerenciamento de Risco desenvolvidos por algumas empresas de equipamentos eletromédicos e que estavam disponíveis na DEC-LEB/EPUSP;

2. Pesquisa feita com outros fabricantes de equipamentos eletromédicos para identificar as principais metodologias utilizadas no Gerenciamento de Risco.

3. Estudo das metodologias FMEA (Failure Mode and Effect Analysis - Análise do tipo e efeito de falha), FTA (Fault Tree Analysis - Análise da Árvore de Falha) e HAZOP (Hazard Operability Analysis - Estudo de Perigo e Operabilidade);

4. Elaboração e/ou Atualização de procedimentos de ensaios de acordo com a nova edição da Norma Geral;

5. Treinamento da equipe técnica da DEC-LEB/EPUSP;

6. Validação dos novos procedimentos;

7. Auditoria do Inmetro.

A realização dessas atividades permitiu a implantação do Gerenciamento de Risco no laboratório de ensaios e, conseqüentemente, a implantação da nova edição da Norma Geral, Colateral e 60601-2-24 com seus devidos procedimentos de ensaios e de gestão. Também ocorreu a capacitação plena da equipe do laboratório em relação a Gerenciamento de Risco.

Toda a infra-estrutura da DEC-LEB/EPUSP foi utilizada para a realização desta pesquisa, incluindo recursos humanos, Normas Técnicas e informações confidenciais. 


\section{RESULtADOS}

Antes do equipamento eletromédico ser comercializado, existirão dois momentos em que será aplicado o Gerenciamento de Risco após a nova edição de a Norma Geral entrar em vigor. Em um primeiro momento, aplicado pelos fabricantes na fase de desenvolvimento e consolidação do produto. Em um segundo momento, pelos laboratórios de ensaios, com o objetivo de certificar se o equipamento está realmente seguro e se as técnicas e procedimentos aplicados pelos fabricantes foram realmente eficazes.

Os resultados apresentados neste capítulo seguirão a sequência de atividades realizadas conforme descritas no capítulo três, mas primeiramente serão apresentados os resultados das comparações das edições da Norma Geral e da Norma 60601-2-24. Alguns dos procedimentos de ensaios desenvolvidos na DECLEB/EPUSP serão apresentados de forma sintetizada em função de sua finalidade ser apenas exemplificar a estrutura, mostrando o que foi acrescentado ao item com a implantação da nova edição da Norma Geral, quais as metodologias, instrumentos e ferramentas utilizadas. Alguns dos ensaios apresentados estão relacionados a Gerenciamento de Risco. Na sequência serão apresentados os ensaios da IEC 60601-1-6:2006, e finalizando, o ensaio de exatidão de dados e controle da Norma IEC 60601-2-24. Para a realização dos ensaios será tomado como exemplo uma bomba de infusão e toda a documentação fornecida pelo seu fabricante. A ordem de apresentação dos procedimentos tanto da Norma Geral quanto da IEC 60601-1-6, se baseará conforme a sequência das seções das próprias Normas.

Optou-se por apresentar somente os ensaios da Norma Colateral IEC 60601 1-6, devido à grande relação que a mesma possui com Gerenciamento de Risco. 


\subsection{AS MUDANÇAS ENTRE AS DUAS EDIÇÕES DA NORMA GERAL}

A nova edição da Norma Geral sofreu algumas mudanças em comparação com a edição de 1997, a começar pelo título, que anteriormente era Prescrições Gerais para Segurança de Equipamentos Eletromédicos e agora é intitulada Requisitos Gerais para a Segurança Básica e Desempenho Essencial de Equipamentos Eletromédicos. O título Desempenho Essencial já traz consigo a questão relacionada a risco, ou seja, se alguma degradação ou problema no equipamento eletromédico resultaria em risco inaceitável. Outra mudança observada foi a substituição dos termos cláusula e subcláusula por seção e subseção. $O$ termo seção significa uma das 17 divisões numeradas no sumário da Norma e subseção significa uma subdivisão numerada de uma seção. Além do mais, algumas formas verbais foram incluídas, como por exemplo, o verbo convém. Este termo significa que a conformidade com um requisito ou um ensaio é recomendada, mas não mandatória, para a conformidade.

A maior mudança e a mais notória é a inclusão de um requisito geral para se realizar um processo de Gerenciamento de Risco. A conformidade com a nova edição da Norma Geral requer que o fabricante implemente um processo de Gerenciamento de Risco em conformidade com a Norma ABNT NBR ISO 14971:2009.

$\mathrm{Na}$ nova edição da Norma Geral, certas seções e subseções da edição anterior foram excluídas, por exemplo, quando a seção ou subseção era indicada como "Não Utilizada". Contudo, as seções e subseções da edição anterior que declaravam "Sem requisito geral" continuam a fazer parte desta nova edição, de maneira que Normas Colaterais e Particulares possam fazer referência a elas. A declaração "Sem requisito geral" foi substituída por uma referência ao processo de Gerenciamento de Risco, porque o "requisito geral" deve ser entendido que, na ausência de uma Norma Colateral ou Particular, esses tópicos sejam tratados pela aplicação de Gerenciamento de Risco.

Outra mudança observada foi a remoção para um anexo normativo sobre proteção contra perigos de ignição de misturas anestésicas inflamáveis. No entanto, esse anexo tinha sido originalmente destinado a ser informativo, devido à raridade 
de tais anestésicos. Entretanto, comentários de comitês nacionais indicaram que alguns fabricantes podem ainda oferecer equipamentos eletromédicos para aplicações que contenham esses perigos.

Além de mudanças no conteúdo com adição de novos ensaios, maior abrangência de outros e adição de novos tópicos, também ocorreram mudanças na estrutura da Norma, ou seja, a disposição e o agrupamento dos ensaios foram aprimorados. Por exemplo, a seção 8 foi extensamente reestruturada para que todos os requisitos relacionados à segurança elétrica estivessem agrupados em apenas uma seção. Outro exemplo é a seção 9, sobre proteção de perigos mecânicos, que foi revisada para considerar uma ampla faixa de perigos que o equipamento eletromédico pode causar ao operador e/ou ao paciente.

Os requisitos da ABNT NBR IEC 60601-1-4:2004 para sistemas eletromédicos programáveis foram incorporados no corpo da nova edição. Os requisitos da ABNT NBR IEC 60601-1-1:2000 para sistemas eletromédicos também foram incorporados na nova edição da Norma Geral.

É importante destacar o importante trabalho realizado por Camargo (2008) ${ }^{[30]}$ ao realizar uma comparação entre as duas edições da Norma Geral.

\subsection{AS MUDANÇAS ENTRE AS DUAS EDIÇÕES DA NORMA 60601-2-24}

Ao comparar as duas edições da Norma 60601-2-24 é possível observar que na edição de 2011 os itens de ensaios são rearranjados para seguir a sequência apresentada pela edição de 2010 da Norma Geral.

Os ensaios são bastante semelhantes nas duas edições desta Norma Particular, excetuando-se o fato de que a edição de 2011 possui mais detalhes em alguns ensaios e elementos sobre Gerenciamento de Risco. O ensaio de exatidão de dados e instrumentos, considerado de grande importância, foi bastante enriquecido devido à edição de 2010 da Norma Geral e suas prescrições para Gerenciamento de Risco, pois as montagens e condições para a realização dos ensaios permanecem iguais nas duas edições da Norma Particular. 
A grande diferença entre as duas é a necessidade somente na edição de 2011, de realizar ensaios segundo as Normas Colaterais IEC 60601-1-6, IEC 606011-8, IEC 60601-1-9, IEC 60601-1-10 e IEC 60601-1-11 sendo que algumas dessas Normas Colaterais, principalmente a 60601-1-6 - Usabilidade, incorpora Gerenciamento de Risco.

\subsection{ESTUDO DO GERENCIAMENTO DE RISCO ELABORADO POR EMPRESAS DE EQUIPAMENTOS ELETROMÉDICOS}

Para este item da pesquisa, foram analisados registros de Gerenciamento de Risco enviados por algumas empresas de equipamentos eletromédicos à DECLEB/EPUSP. Também foi realizada uma pesquisa com outros fabricantes com o intuito de verificar quantas empresas já estão atendendo aos novos requisitos da Norma Geral e quais são as técnicas e ferramentas utilizadas para a implantação do Gerenciamento de Risco. Neste estudo foram analisados arquivos de Gerenciamento de Risco de diferentes equipamentos eletromédicos de diferentes empresas. O objetivo principal desta análise foi estudar diferenciados processos para se fundamentar nos métodos utilizados pelos fabricantes, conseguintemente elaborar procedimentos de ensaios e treinar a equipe DEC-LEB/EPUSP para analisar e interpretar arquivos de Gerenciamento de Risco.

Após analisá-los, foi possível notar que alguns possuem estrutura semelhante ao da Norma ABNT NBR ISO 14971:2009, ou seja, possuem o propósito, definição de termos, descrição geral do produto, análise de risco, avaliação de risco, controle de risco, risco residual, informação de produção e pós-produção e um documento contendo uma descrição da metodologia utilizada para auxiliar o processo total de Gerenciamento de Risco, a saber:

- Propósito:

Neste item é dada uma visão geral do assunto que será abordado no decorrer do arquivo de gerenciamento de risco. 
- Definição de termos:

Neste item os fabricantes definem uma série de termos utilizados no documento.

- Descrição geral do produto:

Neste item são apresentados o nome e o modelo comercial do produto, partes aplicadas, quais são a finalidade, estrutura física, dimensões e características (tensão de alimentação, bateria, potência de entrada, tipo de proteção contra choque elétrico e penetração de líquidos), especificação dos materiais e componentes utilizados para a construção do equipamento, a maneira de operação, preparação antes do uso, fotos, desenhos técnicos e circuitos elétricos. É importante destacar que nem todos os arquivos de gerenciamento de risco possuem todos esses itens descritos anteriormente, pois alguns possuem uma abordagem mais simplificada, já outros possuem uma abordagem mais complexa.

- Análise de risco:

Nesta etapa o fabricante considera todas as características que poderiam afetar a segurança do produto e do usuário. Neste item também são identificados pelos fabricantes todos os perigos, tanto em condição normal quanto em condição de falha.

- Avaliação de risco:

Neste item são tomadas decisões sobre a aceitabilidade do risco. Os fabricantes utilizam os riscos estimados na análise para avaliá-los utilizando o critério para aceitabilidade de risco.

- Controle de risco:

Neste item, os fabricantes utilizam modos para reduzir o risco. Na Norma ABNT NBR ISO 14971:2009 são listados três modos e normalmente um deles é utilizado pelos fabricantes e descrito no arquivo de gerenciamento de risco. Esses modos são: segurança inerente ao projeto, medidas de proteção no próprio produto e informações para a segurança. 
Um fato que precisa ser revisto durante os ensaios, principalmente nos laboratórios, é se o controle do risco foi implementado no projeto final e se a medida implementada de fato reduz o risco.

- Risco residual:

Após a análise, avaliação e controle do risco, este é o ponto onde o fabricante tem que retroceder e considerar o impacto combinado dos riscos residuais individuais. Os fabricantes incluem informações sobre o risco residual significativo. Por exemplo, informam sobre o risco/benefício prescrevendo que o equipamento possui um risco alto, mas também é altamente benéfico para um determinado tratamento.

- Informação de produção e pós-produção:

Este item possui grande importância, pois faz parte do sistema de qualidade da fábrica e a relação com o cliente. O fabricante tem uma realimentação com os clientes coletando e provendo informações a respeito de segurança, efeitos colaterais, geração de risco ao qual pode ocorrer durante o ciclo de vida do equipamento eletromédico. O objetivo desta realimentação é reduzir qualquer risco que poderá ocorrer em outros equipamentos da linha de produção.

Com estas informações de pós-produção, o processo de gerenciamento de risco realmente se torna um processo realimentado de forma repetitiva e em malha fechada.

- Metodologia de análise utilizada no processo de Gerenciamento de Risco Após a análise de arquivos de Gerenciamento de Risco e com pesquisas feitas com outros fabricantes, podem-se destacar três técnicas bastante utilizadas: a Análise de Árvore de Falhas (FTA), Análise do Tipo e Efeito de Falha (FMEA) e Estudos de Perigo e Operabilidade (HAZOP). 


\subsection{ANÁLISE DA PESQUISA FEITA COM OS FABRICANTES DE EQUIPAMENTOS ELETROMÉDICOS}

$\mathrm{Na}$ pesquisa feita com os fabricantes de equipamentos eletromédicos foi enviada uma mensagem com as seguintes questões:

1) A sua empresa já está se adequando às prescrições de Gerenciamento de Risco segundo a Norma ABNT NBR IEC 60601-1:2010 e/ou ABNT NBR ISO 14971:2009? Em caso afirmativo, indicar a(s) Norma(s).

2) Se a resposta à questão 1 for sim, quantas pessoas estão atuando e quais são as áreas de sua empresa envolvidas no processo?

3) Qual (is) é (são) a(s) metodologia(s) sendo utilizada(s) para análise de riscos?

O intuito desta pesquisa foi a de verificar como os fabricantes estão se preparando para a nova edição da Norma Geral, quais setores da empresa estão envolvidos e quais estão sendo as metodologias utilizadas.

Com a questão de número dois, o objetivo foi avaliar o nível de comprometimento da empresa com o Gerenciamento de Riscos, pois é importante um número de setores diferentes participarem, contribuindo com diversas experiências. Por exemplo, o pessoal da engenharia eletrônica contribui para a solução de problemas de circuitos e componentes eletrônicos, o pessoal da computação com problemas relacionados a software, engenharia mecânica com perigos mecânicos e hidráulicos, a equipe da qualidade auxilia aplicando várias ferramentas da qualidade e a área comercial com a realimentação dos clientes que utilizam o produto. Levando em conta equipamentos complexos como, por exemplo, aparelhos de hemodiálise, aparelhos de anestesia e ventilador pulmonar, uma equipe grande, mas não excessiva, pode produzir um melhor resultado.

A questão de número três teve como objetivo verificar as metodologias utilizadas e analisar como os fabricantes estão agindo. É comprovado que muitas metodologias aplicadas de forma única e com poucas pessoas não produzem um resultado tão eficaz, quando utilizada em conjunto com outras técnicas. 
As questões foram enviadas a vinte diferentes fabricantes de diferentes equipamentos eletromédicos como, por exemplo, bomba de infusão, equipamento de hemodiálise, marcapasso, bisturi, oxímetro, equipamento de fototerapia, equipamento a laser e camas hospitalares. Essas empresas foram selecionadas por serem clientes da DEC-LEB/EPUSP. Das vinte empresas, somente onze responderam à pesquisa e, portanto, foi adotado que as outras nove não responderam por ainda não possuirem projeto de implantação e adequação de Gerenciamento de Risco conforme as Normas NBR ISO 14971:2009 e ABNT NBR IEC 60601-1:2010. Conseqüentemente não foram incluídas na apresentação dos resultados. Um dos onze fabricantes respondeu que desconhecia as exigências sobre Gerenciamento de Risco e ainda não havia iniciado as atividades em relação ao assunto. Portanto, apenas dez fabricantes fizeram parte do resultado da pesquisa.

Os resultados obtidos podem ser conferidos a seguir:

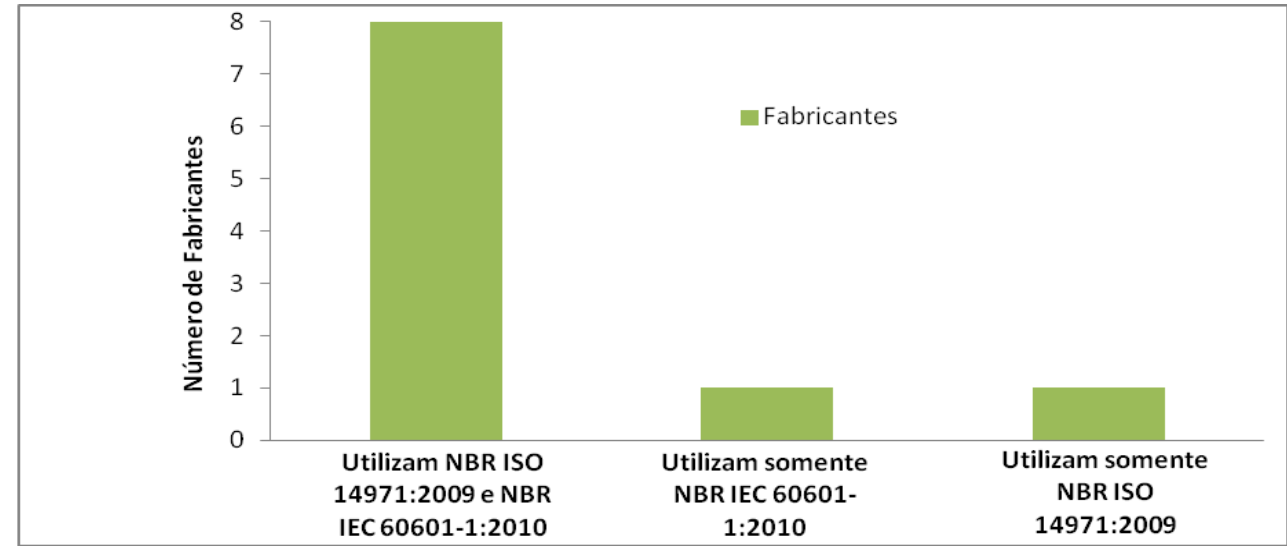

Figura 4.1 - Número de Fabricantes se adequando a nova edição da Norma Geral

A partir da análise da Figura 4.1, pode-se observar que dos dez fabricantes que responderam às questões, oito já estão adequados às duas Normas ou em processo de finalização de suas implantações. Um fabricante respondeu que utiliza apenas a NBR ISO 14971:2009, mas não respondeu se está também se adequando à Norma NBR IEC 60601-1:2010. 


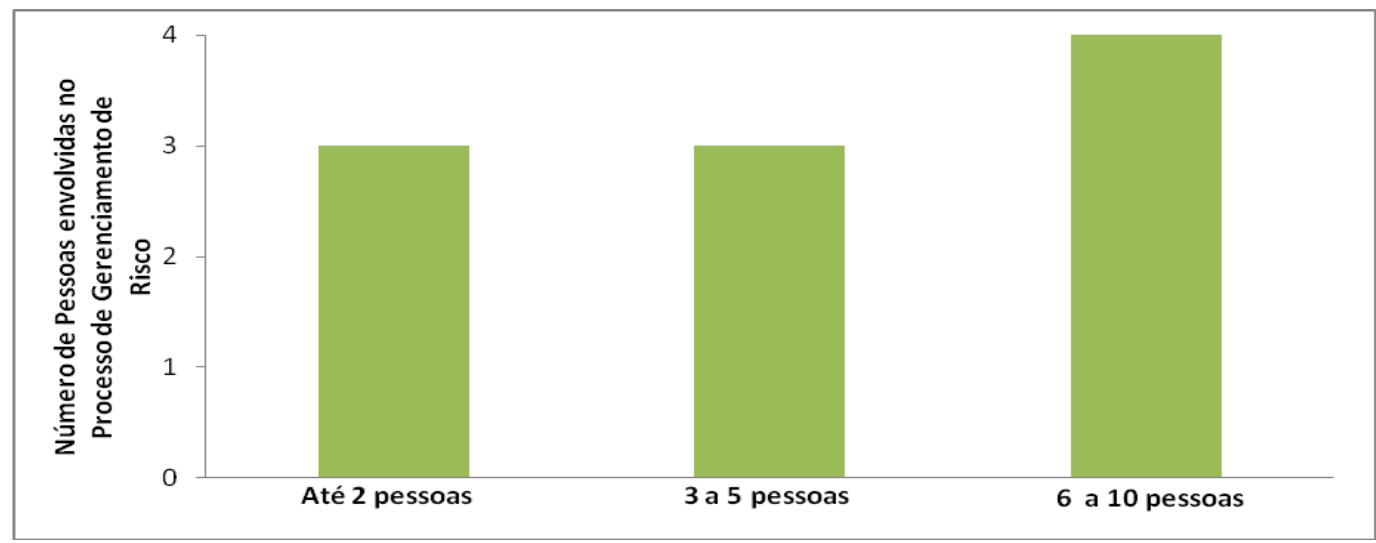

Figura 4.2- Número de Pessoas nas empresas envolvidas com o processo de Gerenciamento de Risco

A partir da análise da Figura 4.2, pode-se observar que $30 \%$ dos fabricantes entrevistados utilizam uma ou duas pessoas para desenvolver o processo de Gerenciamento de Risco. Esse número pequeno de pessoas possivelmente poderá desenvolver um processo não muito completo, pois quanto mais pessoas de diferentes áreas estiverem envolvidas, maior a chance de abranger todas as características do equipamento e, conseqüentemente, maior o sucesso do projeto.

Os principais profissionais envolvidos citados pelas empresas foram Consultores, Projetistas e Desenvolvedores, Profissionais da área de Qualidade, Profissionais da área Comercial, Técnicos em Eletrônica e de Tecnologia da Informação. Dentre os fabricantes que responderam que apenas uma ou duas pessoas estavam envolvidas, suas principais funções eram Profissionais da área da Qualidade e Engenharia \& Desenvolvimento.

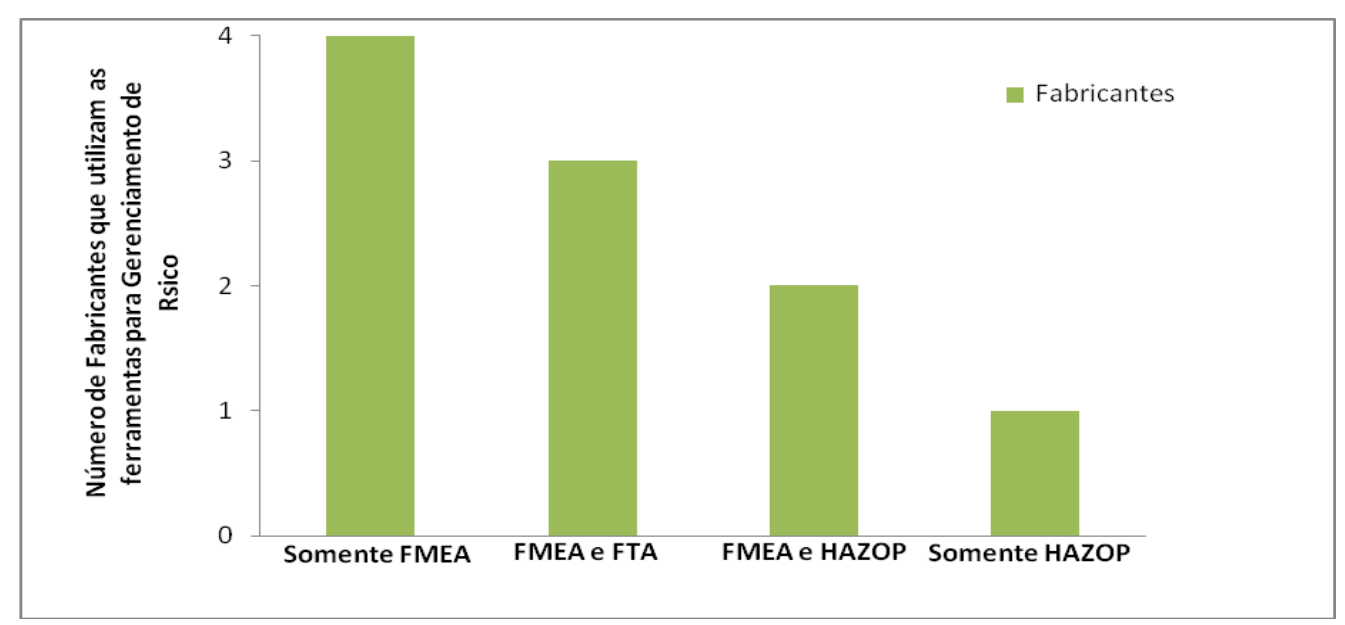

Figura 4.3 - Ferramentas utilizadas na Análise de Risco 
Com a Figura 4.3 é possível verificar que a maior parte dos fabricantes utiliza apenas uma ferramenta, seja ela FMEA (maioria) ou HAZOP. Foi possível verificar também, mesmo com uma variedade de técnicas de Gerenciamento de Risco (aproximadamente 6 indicadas pela NBR ISO 14791:2009), apenas três foram mencionadas na pesquisa pelos fabricantes.

O objetivo de estudar e descrever no capítulo 2 as metodologias FMEA, FTA e HAZOP, decorreu após a análise dos arquivos de Gerenciamento de Risco e a constatação através do questionário enviado aos fabricantes, que essas três metodologias são as freqüentemente utilizadas. A partir deste ponto, observou-se que seria importante para o restante da equipe do laboratório de ensaios aprendêlas para analisar os arquivos de Gerenciamento de Risco com maior maturidade, sabendo exatamente como o fabricante as utilizou, se foram aplicadas de forma correta, se os resultados obtidos foram exatamente os descritos e se o fabricante conseguiu abranger todos os riscos relacionados ao seu equipamento.

\subsection{ELABORAÇÃO E ATUALIZAÇÃO DE PROCEDIMENTOS DE ENSAIOS NA DEC-LEB/EPUSP}

A Norma ABNT NBR ISO IEC 17025:2005 prescreve em um de seus parágrafos: "o laboratório deve utilizar métodos e procedimentos apropriados para todos os ensaios e/ou calibrações dentro do seu escopo".

Em resumo, procedimentos técnicos adequados e detalhados são essenciais para facilitar e agilizar a realização dos ensaios, contribuindo para a qualidade e confiabilidade dos resultados. Conforme prescrito na cláusula 5.4 da Norma ABNT NBR ISO IEC 17025:2005: "os procedimentos de ensaio devem incluir a amostragem, manuseio, transporte, armazenamento e preparação dos itens a serem ensaiados, bem como as técnicas estatísticas para análise dos dados de ensaios e/ou calibração" e "o laboratório deve ter instruções sobre o uso e a operação de todos os instrumentos pertinentes, sobre o manuseio e preparação dos itens sob ensaio, onde a falta de tais instruções possa comprometer os resultados. Todas as instruções, Normas Técnicas, Manuais devem ser mantidos atualizados e 
prontamente disponíveis". Tosas estas prescrições são indispensáveis para obter um bom procedimento técnico.

Para elaboração de um procedimento técnico é de fundamental importância que o responsável tenha conhecimento da Norma Técnica que referencia o procedimento a ser realizado. A disposição e manuseio dos instrumentos necessários desde a montagem dos arranjos de ensaios até a operação correta de todos os itens é outro fator importante. É imprescindível também que o ensaiador tenha conhecimento básico de cálculos de incerteza das medidas para poder adicionar estas informações aos resultados. E, atualmente, deve ter um conhecimento amplo e consolidado de Gerenciamento de Risco.

A seguir são apresentadas as etapas que foram desenvolvidas na DECLEB/EPUSP para a elaboração dos procedimentos de ensaios:

- Estudo das Normas Técnicas de referência para os ensaios. Neste caso, foram estudadas a Norma ABNT NBR IEC 60601-1:2010 a Norma ABNT NBR ISO 14971:2009, Normas Colaterais e a Norma IEC 60601-2-24;

- Discussão e interpretação dos pontos que apresentam maior dificuldade de ensaios;

- Descrição dos instrumentos, softwares, arranjos e Normas adicionais necessários para cada ensaio;

- Desenvolvimento de métodos concisos e de fácil interpretação para todos os ensaiadores do laboratório.

Os procedimentos foram elaborados a partir da seção 4 até a seção 16 da Norma Geral. É importante destacar que a seção 5 prescreve somente requisitos gerais, ou seja, só existem recomendações e não ensaios, já a seção 17 são prescritos ensaios de compatibilidade eletromagnética não realizados pela DECLEB/EPUSP. Excetuando-se estas duas seções, para as demais foram elaborados procedimentos de ensaios.

Após a análise das duas Normas tanto a ABNT NBR ISO 14971:2009 quanto a Norma Geral e um estudo amplo de Gerenciamento de Risco deu-se início à elaboração dos procedimentos. O formato utilizado para os procedimentos foi discutido e aprovado pela Gerencia da Qualidade, ou seja, todos os documentos deveriam conter os seguintes itens:

- Nome da Norma. 
- Assunto: Neste item é descrito o título do ensaio.

- Objetivo: Neste item é descrito de forma sucinta o objetivo e a realização do ensaio.

- Informações adicionais: Neste item são feitas as críticas e dadas às sugestões para a realização dos ensaios e melhorias dos futuros procedimentos.

- Materiais utilizados: Neste item são descritos todos os instrumentos, gigas e documentos adicionais necessários para a realização dos ensaios.

- Procedimento: Neste item é descrito detalhadamente a maneira de realização dos ensaios

- Incertezas de medição: Neste item é descrito o passo a passo para calcular a incerteza de medição e a maneira de descrevê-la no relatório.

- Referências Bibliográficas.

O formato adotado foi utilizado por dois motivos, primeiro: para padronizar todos os documentos e ensaios; segundo: conforme uma pesquisa realizada com toda a equipe, foi determinado como sendo a maneira mais clara para ter um procedimento de ensaios no Laboratório e conseguir realizar a análise de todo o processo de forma uniforme e homogênea.

Devido à questão de sigilo da DEC-LEB/EPUSP em relação a seus procedimentos de ensaios, não foi possível descrevê-los detalhadamente, mas foi mostrado somente o formato adotado, pois um dos fatores que influencia na concorrência por melhores prazos e preços entre os laboratórios são seus materiais, instrumentos e as técnicas descritas nos procedimentos utilizados para a execução dos ensaios.

\subsection{TREINAMENTO DA EQUIPE TÉCNICA}

Como o tema Gerenciamento de Risco é um assunto novo quando aplicado a ensaios de equipamentos eletromédicos e, nem todos os integrantes da equipe da DEC-LEB/EPUSP estavam familiarizados, um fator importante foi o treinamento feito 
em etapas para o melhor entendimento do assunto por todos os integrantes do laboratório de ensaios.

A princípio, para a familiarização com o assunto, toda a equipe da DECLEB/EPUSP foi instruída com informações de um expositor contratado para treinálos sobre Gerenciamento de Risco. O curso teve duração de aproximadamente 4 horas de aula, contando com o auxílio de materiais de apoio.

A segunda etapa consistiu em reunir toda a equipe para assistir ao exame de qualificação da dissertação de mestrado Gerenciamento de Risco, Diego Antonio de Oliveira Rosa no mês de abril de 2011.

A terceira etapa consistiu em apresentar um curso aos demais integrantes com todos os tópicos abordados por este trabalho. O curso teve duração de dez horas e aplicado em dois dias. O material utilizado foi um resumo da Norma ABNT NBR ISO 14971:2009 e das metodologias FMEA, FTA e HAZOP. Esta etapa foi muito importante para todos aumentarem seus conhecimentos, pois foi aberta à discussões, dúvidas e exposições de idéias.

Ao final destas etapas pode-se formar uma forte base teórica nos integrantes da DEC-LEB/EPUSP para ensaiar equipamentos eletromédicos de acordo com as novas prescrições da Norma Geral. É importante ressaltar que toda a equipe já possuía no mínimo dois anos de experiência na realização de ensaios de equipamentos eletromédicos pelas antigas edições das Normas técnicas da série ABNT NBR IEC 60601, fato que facilitou a introdução do Gerenciamento de Risco e o aprimoramento de todos os integrantes.

Dependendo da agenda de atividades do laboratório, devem-se realizar pequenos cursos de reciclagem. Estes cursos estão programados para serem realizados semestralmente e o objetivo principal é a troca de experiências entre os participantes sobre a análise dos arquivos de Gerenciamento de Risco, pois o processo de aprendizado deve ser contínuo e não apenas realizar uma avaliação para a medição do conhecimento momentâneo e, deste modo, finalizar o processo. 


\subsection{PROCESSO DE VALIDAÇÃO DOS PROCEDIMENTOS DE ENSAIOS NA DEC-LEB/EPUSP}

Posteriormente ao desenvolvimento de um determinado procedimento de ensaios é necessária a validação do mesmo. A validação é "a confirmação por análise crítica de que os requisitos descritos no procedimento elaborado são satisfatórios para ensaiar corretamente o equipamento eletromédico" (Norma ABNT NBR ISO IEC 17025:2005, p. 15).

Após o treinamento da equipe o passo seguinte consistiu em validar os procedimentos de ensaios criados. A metodologia utilizada foi à seguinte:

1) Foram distribuídos os procedimentos para cada integrante da equipe;

2) Os ensaiadores do laboratório liam e realizavam correções ortográficas, realizavam os ensaios, faziam críticas e proporcionavam sugestões;

3) Os procedimentos passavam por uma nova atualização;

4) O procedimento era passado a um terceiro ensaiador do laboratório que fazia novamente correções ortográficas (se necessário), realizava os ensaios, fazia críticas e proporcionava sugestões;

5) Os procedimentos passavam novamente pela atualização;

6) Os procedimentos eram analisados pela alta direção do laboratório e, se estivessem satisfatórios, eram aprovados, mas se não, eram novamente reescritos de acordo com as opiniões da alta direção.

Após os procedimentos passarem por essa sequência de atividades foram validados. O mesmo equipamento eletromédico foi ensaiado por toda a equipe e os resultados obtidos após os ensaios foram muito próximos. É importante destacar que os procedimentos precisam ser atualizados constantemente, devido ao processo de Gerenciamento de Risco ser subjetivo. Um mesmo equipamento eletromédico, por exemplo, uma bomba de infusão, produzida por diferentes fabricantes apresenta diferentes graus de detalhamentos nos arquivos de Gerenciamento de Risco. Com o tempo e com a experiência de cada integrante da equipe do laboratório na análise destes arquivos, os procedimentos deverão ser melhorados continuamente. 


\subsection{PROCEDIMENTOS DE ENSAIOS DA NORMA 60601-1:2010}

A seguir serão apresentados os procedimentos conforme a sequência da própria Norma Geral. Inicialmente serão apresentados alguns ensaios mecânicos da seção 9, pois foram adicionados à nova edição da Norma Geral, portanto não havia na edição de 1997, em seguida os de exatidão de controles, instrumentos e proteção contra saída perigosa da seção 12, e finalizando, os ensaios para Sistemas Eletromédicos Programáveis da seção 14.

Todos os ensaios apresentados neste item são apenas aqueles que possuem relação com Gerenciamento de Risco e aplicáveis à bomba de infusão.

\subsubsection{Ensaios da Seção 9 da Norma Geral (Ensaios Mecânicos)}

\subsubsection{Espaços Livres e Guardas Móveis}

Os ensaios descritos a seguir, estão relacionados à zona de armadilhai e guardasii,, onde na maioria dos casos é necessário além de fazer inspeção no equipamento, é preciso fazer a análise dos arquivos de Gerenciamento de Risco. Ao fazer a análise dos arquivos, é necessário verificar se o risco foi tratado corretamente pelos fabricantes e verificar se o risco residual é aceitável.

Para a realização do ensaio de Espaços Livres, é necessário primeiramente verificar se o equipamento possui uma zona de armadilha. Se o equipamento possuir, é necessário verificar se os espaços livres da zona de armadilha podem ser

\footnotetext{
' Local acessível sobre ou dentro do equipamento eletromédico, sistema eletromédico ou no ambiente do equipamento onde um corpo humano ou parte do corpo humano é exposto a um perigo de armadilha, esmagamento, cisalhamento, impacto, corte ou seccionamento, emaranhamento, trespassamento ou perfuração, fricção ou abrasão.

ii Parte do equipamento utilizada especificamente para fornecer proteção por meio de uma barreira física. Dependendo de sua construção, uma guarda pode ser chamada de invólucro, tampa, blindagem, porta, guarda envolvente.
} 
considerados como um perigo mecânico. Para não serem considerados como perigo mecânico, os espaços livres devem estar em conformidade com a Figura 4.4. Neste ensaio é utilizado um paquímetro e uma escala calibrada de $1 \mathrm{~m}$ para a realização das medições.

\begin{tabular}{|c|c|c|c|}
\hline Parte do corpo & $\begin{array}{c}\text { Adulto } \\
\text { espaço livre a } \\
\mathrm{mm}\end{array}$ & $\begin{array}{c}\text { Criança } \\
\text { espaço livre a } \\
\mathrm{mm}\end{array}$ & Ilustraçăo \\
\hline Corpo & $>500$ & $>500$ & \\
\hline Cabeça & $>300$ ou $<120$ & $>300$ ou $<60$ & \\
\hline Perna & $>180$ & $>180$ & \\
\hline Pé & $>120$ ou $<35$ & $>120$ ou $<25$ & \\
\hline Dedos do pé & $>50$ & $>50$ & \\
\hline Braço & $>120$ & $>120$ & \\
\hline Măo, pulso, punho & $>100$ & $>100$ & \\
\hline Dedo & $>25$ ou $<8$ & $>25$ ou $<4$ & \\
\hline
\end{tabular}

Figura 4.4 - Espaços Livres aceitáveis Fonte: ABNT NBR IEC 60601-1:2010 


\section{- Resultado do ensaio de espaço livre e Guardas Móveis}

Após uma inspeção feita no equipamento foi constado que a bomba de infusão ensaiada não possuía zona de armadilha.

\subsubsection{Guardas Móveis}

Para a realização deste ensaio, primeiramente é necessário verificar se as guardas móveis podem ser abertas sem a utilização de uma ferramenta. Se a resposta for afirmativa, uma das seguintes condições deve ser satisfeita:

- Devem continuar afixadas ao equipamento eletromédico quando a guarda está aberta;

- Devem ser associadas com um dispositivo de intertravamento que previna que as partes móveis pertinentes comecem a se mover enquanto a zona de armadilha estiver acessível e pára o movimento quando a guarda estiver aberta;

- Devem ser projetadas de tal maneira que a falta ou falha de um de seus componentes previna o começo da movimentação das partes móveis e pára as partes móveis.

\section{- Resultado do ensaio de Guardas Móveis}

Após inspecionar a bomba de infusão sob ensaio, foi verificado que a mesma possui guarda móvel. A guarda móvel encontrada na bomba de infusão é a tampa que protege o rolete do motor (Figura 4.5). O rolete é a parte do equipamento que pressiona o equipo fazendo com que o líquido flua em direção ao paciente.

Com o equipamento em funcionamento, ao abrir a tampa, é acionado um alarme sonoro e visual e a infusão é interrompida protegendo o paciente de sobreinfunsão ou subinfusão.

Ao analisar os arquivos de Gerenciamento de Risco, não foi encontrada nenhuma informação sobre um possível risco ao paciente envolvendo uma possível falha do sistema de alarme de abertura da tampa. 


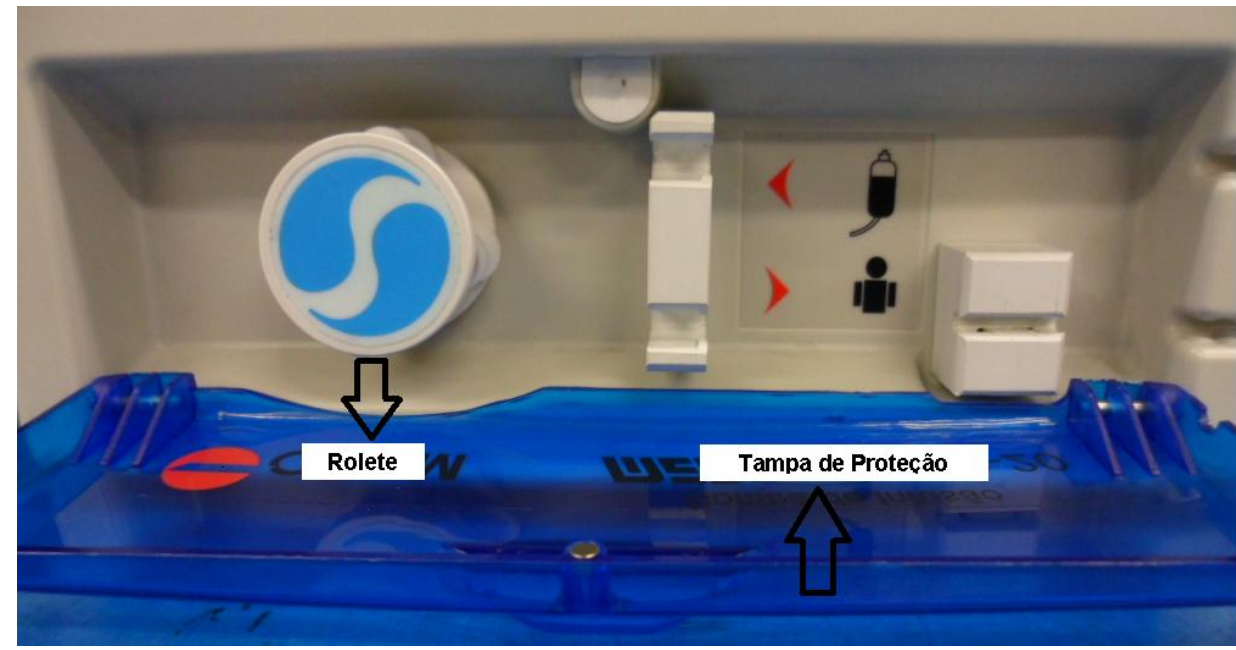

Figura 4.5 - Rolete e tampa de proteção do sistema mecânico de infusão

\subsubsection{Providências de Proteção}

As providências de proteção devem ser projetadas e incorporadas ao sistema de controle de tal maneira que:

- As partes móveis não possam se mover enquanto elas estiverem ao alcance de pessoas;

- Após as partes móveis do equipamento começarem a se mover, a zona de armadilha não pode ser alcançada, ou se for alcançável, o movimento do sistema deve parar. Nenhum dano deve ocorrer;

Para este ensaio, o equipamento deve ser inspecionado durante o uso e o arquivo de Gerenciamento de Risco analisado.

- Resultado do ensaio de Providências de Proteção

Para este ensaio foi verificado que a parte móvel (rolete) não se move enquanto estiver ao alcance de pessoas (tampa de proteção aberta). 


\subsubsection{Perigos de Partes Expelidas}

Onde partes expelidas podem resultar em um risco inaceitável, o equipamento eletromédico deve ser fornecido com um meio para a proteção contra o risco.

Para este ensaio, o equipamento deve ser inspecionado durante o uso e o arquivo de Gerenciamento de Risco analisado.

\section{- Resultado do ensaio de Perigos de Partes Expelidas}

Após inspecionar o equipamento foi constatado que nenhuma parte que poderia ser expelida pode resultar em risco. Também não foram encontradas informações relacionadas a partes que podem ser expelidas e possíveis riscos no arquivo de Gerenciamento de Risco. Para este item de ensaio, a falta de informação do fabricante resulta em uma não conformidade.

\section{- Comentários}

Considerando os desgastes das partes mecânicas com tempo de uso, seria interessante o fabricante adicionar alguma informação relacionada no arquivo de Gerenciamento de Risco. Por exemplo, efetuar a manutenção preventiva com periodicidade em um determinado " $\Delta \mathrm{t}$ " nas partes mecânicas, para evitar que algum componente possa ser expelido e provoque alteração na infusão.

\subsubsection{Energia Acústica incluindo infrassom e ultrassom}

Este ensaio foi adicionado à Norma Geral pelos seguintes motivos:

- Em algumas Normas particulares havia prescrição, já para outras não, portanto os comitês desenvolvedores de Normas da série 60601 resolveram aplicar a todos os equipamentos, inclusive para aqueles que não possuem Normas Particulares; 
- Ruído excessivo pode causar interferência à fala, sinais acústicos ou mesmo danos à audição.

- Em locais de utilização médica, limites muito mais baixos são necessários para o conforto de pacientes e pessoais médicos;

- A maior parte dos equipamentos eletromédicos expõe o paciente e o operador ou outras pessoas a níveis negligenciáveis de ruído e vibração. Convém que o processo de Gerenciamento de Risco seja capaz de identificar de forma clara aqueles casos onde medições são necessárias.

Em utilização normal o paciente e operador não devem ser expostos à energia acústica advindas do equipamento eletromédico que excedem os níveis especificados a seguir, exceto sons de sinais de alarmes sonoros:

- $80 \mathrm{~dB}(\mathrm{~A})$ para uma exposição cumulativa de 24 horas em um intervalo de tempo de 24horas;

- $140 d B$ nível de pressão sonora não ponderada para energia impulsiva ou de ruído.

Para a realização deste ensaio é utilizado um decibelímetro, marca $01 \mathrm{~dB}$, modelo SdB02. O ensaio é verificado por medição do máximo nível de pressão sonora ponderada em A, na distância mínima do paciente-operador da fonte de energia acústica (ruído).

\section{- Resultado do ensaio de energia acústica}

Para a realização deste ensaio foi adotada a distância de 1 metro do equipamento. Esta distância foi adotada, tomando como base a especificação da Norma IEC 60601-2-24 que solicita a medição da pressão sonora dos alarmes a 1 metro do equipamento. Mas, também poderia ser medido a qualquer distância do equipamento, pois a Norma Geral não especifica.

As seguintes condições foram adotadas: foram realizadas 5 medições da pressão sonora e 5 medições do ruído produzido pelo equipamento em utilização normal. Os ensaios foram realizados em um ambiente com ruído externo mínimo, ou seja, somente com o equipamento sob ensaio ligado.

Após os ensaios os seguintes resultados foram obtidos:

- Pressão sonora do alarme: $(67,70 \pm 2,30) \mathrm{dB}(\mathrm{A})$;

- Ruído produzido pelo equipamento: $(35,48 \pm 0,90) \mathrm{dB}(\mathrm{A})$; 
Com esses resultados pode-se concluir que a pressão sonora e nem o ruído do equipamento atinge os $80 \mathrm{~dB}(\mathrm{~A})$ especificados pela Norma.

Nos arquivos de Gerenciamento de Risco fornecidos pelo fabricante não foram encontradas informações a respeito de energia acústica e os riscos relacionados.

\subsubsection{Ensaios de Exatidão de Controles, Instrumentos e Proteção contra Saída Perigosa}

Na edição da Norma Geral de 1997 não há prescrições para serem ensaiadas pelo item anteriormente intitulado "Exatidão de dados de operação e proteção contra saída incorreta de dados". Já a edição da Norma Geral de 2010, apresenta na seção 12 o título "Exatidão de controles, instrumentos e proteção contra saída perigosa" e há prescrição de ensaios para exatidão de controle e instrumentos, usabilidade, sistemas de alarme, indicação de parâmetros pertinentes a segurança, seleção acidental de valores excessivos de saída e saída incorreta, conforme detalhados a seguir.

\subsubsection{Exatidão de Controle e Instrumento}

O ensaio consiste em verificar no processo de Gerenciamento de Risco, se o fabricante do equipamento eletromédico leva em consideração os riscos associados com a exatidão de controle e instrumentos. Para a verificação deste item de ensaio é necessário fazer uma análise do arquivo de Gerenciamento de Risco fornecido pelo fabricante.

Os riscos associados com o ensaio podem ser, por exemplo, a falha de algum componente que causará algum distúrbio na exatidão de controle, ou uma falha no sistema de alarme que impossibilite a exatidão dos dados. Como neste item é 
necessária apenas a verificação do arquivo de Gerenciamento de Risco, houve a preocupação em treinar a equipe da DEC-LEB/EPUSP para fazer a análise da documentação.

\section{- Resultados dos ensaios de exatidão de controle e instrumento}

Dependendo do componente que apresentar problema (falha) afetará diretamente na exatidão. Após a análise nos arquivos de Gerenciamento de Risco, o fabricante classificou os riscos associados com a exatidão do instrumento de gravíssimo, sendo que a escala de classificação utilizada foi: gravíssimo, grave, moderado e leve. Os seguintes perigos foram apontados: aumento momentâneo da vazão, aumento sustentado da vazão. Para que ocorra este tipo de perigo e consequentemente um possível dano ao paciente, as falhas conforme descritas na Tabela 4.1 foram identificadas pelo fabricante.

Tabela 4.1 - Falhas identificadas pelo fabricante

\begin{tabular}{|l|l|}
\hline \multicolumn{1}{|c|}{ Tipo } & \multicolumn{1}{c|}{ Condição de falha } \\
\hline Ocorrências na Infusão & Ar no equipo \\
\hline Ocorrências na Infusão & $\begin{array}{l}\text { Interferências eletromagnéticas que podem afetar o } \\
\text { desempenho da bomba }\end{array}$ \\
\hline Ocorrências na Infusão & Desconexão do sensor de gotas \\
\hline Ocorrências na Infusão & $\begin{array}{l}\text { Veia do paciente pode ficar obstruída durante a } \\
\text { infusão }\end{array}$ \\
\hline Ocorrências na Infusão & $\begin{array}{l}\text { Vazamento no equipo na junção da parte de silicone } \\
\text { destinada a ser conectada no rolete. }\end{array}$ \\
\hline
\end{tabular}

Um ponto crítico para este ensaio é que, dependendo do fabricante, haverá diferença nos perigos levantados, tanto em quantidade, como em qualidade.

\subsubsection{Usabilidade}

Usabilidade é a "característica que estabelece eficácia, eficiência, aprendizagem e satisfação do operador" (ABNT NBR IEC 60601-1:2010, p. 29). 
Para este subitem é importante esclarecer a introdução do conceito de usabilidade. Este termo foi escolhido para substituir os termos "erros do usuário" ou "erro humano" utilizados na edição de 1997 da Norma Geral. Nem todos os erros são resultados da falta ou excesso de atenção do operador. Muito frequentemente, erro de utilização é o resultado direto de um mau projeto da interface humana que induz o operador a tomar uma decisão incorreta.

Neste subitem é necessário verificar no processo de engenharia de usabilidade, o risco de má usabilidade. O processo de engenharia de usabilidade é um documento onde o fabricante descreve o conhecimento sobre o comportamento humano, habilidades, limitações e outras características para o projeto de ferramentas, máquinas, equipamentos, dispositivos, sistemas, tarefas e trabalhos para conseguir a usabilidade adequada ${ }^{[1]}$. Neste documento deve ser feita uma análise dos riscos de má usabilidade associados com a marcação, identificação e documentos acompanhantes. Para este subitem foi realizado um treinamento com a equipe da DEC-LEB/EPUSP, apresentados os termos usabilidade e engenharia de usabilidade, assim como, os tipos de risco que poderia ser causado pela má usabilidade. Por exemplo, um mau entendimento da documentação ou marcação poderia levar a uma interpretação errada e consequentemente à montagem e/ou operação incorretas do equipamento eletromédico.

\section{- Resultado do Ensaio de Usabilidade}

No arquivo de Gerenciamento de Risco fornecido por uma empresa de bombas de infusão não havia informações sobre possíveis riscos relacionados à Usabilidade. Neste caso é informado no Relatório de Ensaios no item 12.2 da Norma ABNT NBR IEC 60601-1:2010 que não foram encontradas informações sobre usabilidade.

\subsubsection{Sistemas de Alarme}

Este subitem especifica que o fabricante deve levar em consideração, no processo de Gerenciamento de Risco, a necessidades de sistemas de alarme como meio de controle de risco, e deve levar em consideração também qualquer risco 
associado com a operação ou falha do sistema de alarme. Para verificar a conformidade deste ensaio é necessário fazer uma análise no arquivo de Gerenciamento de Risco enviado pelo fabricante.

No caso de um ensaio em Bombas de Infusão, um exemplo seria verificar na documentação os cuidados e o funcionamento que o fabricante propôs para os alarmes que controlam a infusão. Se ocorrer algo com o alarme que controla a infusão, ocorrerá o risco de uma quantidade maior ou menor de medicamento chegar ao paciente e, deste modo, comprometer o tratamento. Além do mais, é necessário fazer uma análise minuciosa utilizando as metodologias FMEA e FTA no sistema de alarme de controle da infusão, para saber em quais situações poderia causar uma falha. Para este tipo de ensaio foi realizado um treinamento na DECLEB/EPUSP visando à familiarização de todos com as metodologias FMEA, FTA e HAZOP. Outro fator importante é o conhecimento do ensaiador do laboratório no equipamento ensaiado, pois este conhecimento conta muito para a realização da análise.

\section{- Resultado do ensaio de Sistema de Alarme}

Não foi encontrada nos arquivos de Gerenciamento de Risco, uma análise dos riscos, no caso de qualquer falha no sistema de alarme.

O fabricante utiliza no equipamento os seguintes sistemas de alarme para controle de risco relacionado à infusão:

- Alarme de bolhas: Protege o paciente de bolhas que poderiam causar embolia gasosa;

- Alarme de oclusão: Avisa quando o paciente não está recebendo o medicamento. Com uma vazão de $25 \mathrm{ml} / \mathrm{h}$ e com o equipo sendo ocluído na sua extremidade, o equipamento levou cerca de 2 minutos e 61 segundos para acionar um alarme visual e sonoro;

- Alarme de Fluxo Livre: Este alarme é acionado quando a infusão é maior do que a programada pelo operador. O alarme leva em torno de alguns segundos para ser acionado. 


\subsubsection{Indicação de Parâmetros pertinentes à segurança}

Para este ensaio o fabricante deve levar em consideração, no processo de Gerenciamento de Risco, a necessidade de indicação de parâmetros que são associados com saídas perigosas. A conformidade para este item é verificada através de uma análise dos arquivos de Gerenciamento de Risco.

Este item consiste basicamente em verificar se o fabricante fez uma análise dos parâmetros, sejam eles de energia, taxa ou volume e os indicou corretamente no equipamento, além de ter relatado os cuidados e os trabalhos realizados.

\section{- Resultado do ensaio de Parâmetros Pertinentes à Segurança}

Após a análise dos arquivos de Gerenciamento de Risco, verificou-se se as saídas perigosas possuem indicação de parâmetros. As saídas perigosas definidas pelo fabricante são a função bolus e a função preenchimento do equipo. As duas funções para serem acessadas possuem "barreiras" através de uma sequência de comandos. Quando as funções bolus ou preenchimento são acessados, é informada no display do equipamento a quantidade de líquido em $\mathrm{ml}$ (mililitros) que é infundida durante a sua utilização. A função bolus é considerada uma saída perigosa, pois quando utilizada, entrega ao paciente uma quantidade grande de medicamento em um curto tempo. A função preenchimento é utilizada para preencher o equipo com medicamento antes de instalá-lo no paciente. Outra precaução tomada pelo fabricante foi à imposição de um alarme sonoro quando as funções são utilizadas. Inúmeros bips podem ser ouvidos para indicar a execução de cada função ao usuário.

Para a bomba de infusão ensaiada, os resultados obtidos foram considerados suficientes.

\subsubsection{Seleção acidental de valores excessivos de saída}

É necessário verificar neste ensaio se o equipamento eletromédico é uma unidade com múltiplas finalidades que fornece saídas de baixa intensidade e de alta 
intensidade para diferentes tratamentos. Se o equipamento possuir estas características, é necessário verificar se o fabricante levou em consideração no processo de gerenciamento de risco os riscos associados com seleção acidental de valores excessivos de saída.

Para este subitem, muitas vezes o fabricante descreve que para liberar a saída, após serem ajustados os valores, necessariamente o usuário precisa ainda pressionar mais uma tecla, ou seja, mais uma barreira para evitar a saída incorreta. Uma alternativa que pode ser verificada nos arquivos de Gerenciamento de Risco é a menção a pesquisas científicas prescrevendo que determinadas doses por determinados tempos não causariam nenhum efeito ou causariam efeitos se passado um dado tempo " $\Delta \mathrm{t}$ " de aplicação.

\section{- Resultado do ensaio de seleção acidental de valores excessivos de saídas}

Uma bomba de infusão possui uma ampla faixa de vazão, podendo variar de $0,1 \mathrm{ml} / \mathrm{h}$ a $999,99 \mathrm{ml} / \mathrm{h}$.

Para a bomba de infusão ensaiada, a seguinte mensagem foi utilizada antes que o operador pudesse iniciar a infusão: "O volume total e a vazão selecionada estão corretos?" Só após o operador selecionar o item "sim" a bomba começa a funcionar. O fabricante, para este subitem de ensaio, solucionou o problema de seleção acidental impondo uma "barreira" antes de iniciar a infusão do medicamento, ou seja, o operador precisa "revisar" os valores selecionados.

\subsubsection{Saída incorreta}

Neste ensaio o fabricante deve levar em consideração os riscos associados com saída incorreta no processo de Gerenciamento de Risco.

Para este subitem são verificados erros causados pelo equipamento e não erros de ajustes de valores pelo usuário. Os riscos associados com saída incorreta podem ser verificados através de um alarme que aciona para alertar qualquer desvio quando o valor selecionado não é proporcional ao entregue ao paciente. 
Analisando os arquivos de Gerenciamento de Risco é possível fazer um rastreamento do que aconteceria se este alarme falhasse, ou caso ocorresse esta falha quais seriam as consequências ao paciente e, finalmente, os cuidados que o fabricante teve em descrever sobre o sistema de alarme, incluindo informações sobre o nível de informações, clareza, organização do conteúdo.

\section{- Resultados dos ensaios de saída incorreta.}

Os perigos que poderiam causar riscos ao paciente devido à saída incorreta relacionados pelo fabricante foram: deixar a câmara de gotejamento muito cheia, deixar a câmara de gotejamento muito vazia, não colocar o sensor de gotas na câmara de gotejamento, instalar incorretamente o sensor de gotas na câmara de gotejamento, utilizar equipos diferentes daqueles indicados pelo fabricante, não conectar corretamente o equipo no equipamento, não abrir a pinça corta fluxo antes de iniciar a infusão.

\section{- Comentários.}

O fabricante levantou alguns perigos com possíveis riscos, mas poderiam ser levantados outros mais, por exemplo, um possível problema com a função bolus, erro do software, problemas de vazamento no equipo, diferentes alturas da câmara de gotejamento em relação ao paciente. O fabricante poderia ter detalhado melhor e aprofundado neste item de ensaio tão importante, pois há uma série de perigos e possíveis riscos ao paciente.

\subsubsection{Sistemas Eletromédicos Programáveis}

Um sistema eletromédico programável é um equipamento eletromédico ou sistema eletromédico contendo um ou mais subsistemas eletrônicos, ou seja, é um sistema baseado em uma ou mais unidades centrais de processamento que inclui softwares e interfaces.

A seção 14 da edição da Norma Geral de 2010 prescreve um conjunto de recursos e atividades para ser seguido através do ciclo de vida de desenvolvimento 
do equipamento eletromédico. Neste item são definidos os elementos mínimos do ciclo de vida de desenvolvimento do Sistema Eletromédico Programável e apenas os requisitos adicionais que necessitam ser considerados parte do processo de Gerenciamento de Risco. Segundo a própria Norma Geral, ciclo de vida são as atividades necessárias que ocorrem durante o intervalo de tempo, desde a fase de concepção do projeto e se encerra quando a validação (avaliação para determinar se o produto satisfaz os requisitos para a sua utilização destinada) se completa.

Para este subitem, são verificados através de inspeção do arquivo de Gerenciamento de Risco os itens sobre documentação, plano de Gerenciamento de Risco, ciclo de vida de desenvolvimento, resolução de problemas, processo de Gerenciamento de Risco, projeto e implementação, verificação e validação. Para estes itens foi feito um treinamento com toda a equipe do laboratório de Ensaios enfatizando o processo de Gerenciamento de Risco e mais precisamente os elementos mínimos do ciclo de vida.

Ao analisar este item percebeu-se que tudo é muito subjetivo e o trabalho se torna mais documental do que prático. A Norma prescreve os ensaios, mas não diz como o fabricante deve implantá-los e nem como os laboratórios de ensaios devem avaliar o trabalho realizado pelos fabricantes.

Os ensaios descritos a seguir não são aplicáveis à bomba de infusão utilizada neste trabalho, pois o equipamento não se encaixa no conceito de Sistema Eletromédico Programável.

\subsubsection{Documentação}

Neste item, o fabricante além dos documentos prescritos pela ABNT NBR ISO 14971:2009, deve elaborar documentos produzidos a partir da aplicação de todas as prescrições para Sistemas Eletromédicos Programáveis. A Figura 4.6 deve ser utilizada para diretrizes gerais. 


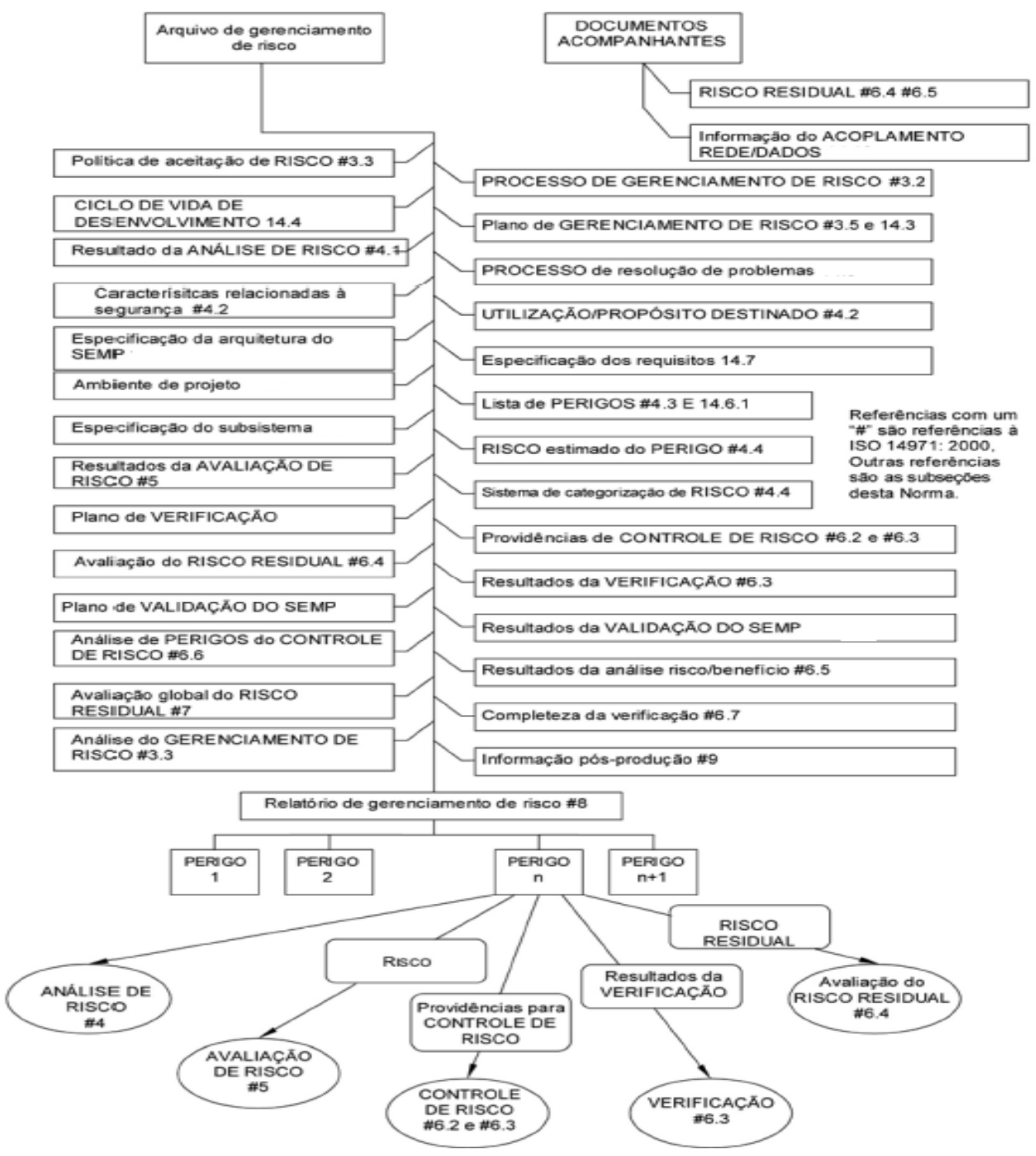

Figura 4.6- Documentação de requisitos para Sistema Eletromédico Programável Fonte: ABNT NBR IEC 60601-1:2010.

\subsubsection{Plano de Gerenciamento de Risco}

O plano de Gerenciamento de Risco prescrito por 3.5 da ABNT NBR ISO 14971:2009 deve incluir uma referência ao plano de validação do Sistema Eletromédico Programável (processo de avaliação durante ou no final do processo de desenvolvimento do Sistema Eletromédico ou de um componente).

O item 3.5 da ABNT NBR ISO 14971:2009 prescreve que o fabricante deve manter um arquivo de Gerenciamento de Risco fornecendo rastreabilidade à análise 
de risco, avaliação de risco, implementação e medidas de controle e aceitabilidade de riscos residuais.

Para este ensaio é necessário analisar todo o arquivo de Gerenciamento de Risco, verificando se foram atendidas as prescrições do item 3.5 da ABNT NBR ISO 14971:2009 e, se o processo de avaliação foi efetuado.

\subsubsection{Processo de Gerenciamento de Risco (Identificação de Perigos)}

Neste item de ensaio é preciso verificar se o fabricante considerou no processo de Gerenciamento de Risco, os perigos associados com aspectos de hardware e software, incluindo aqueles associados com componentes de origem de terceira parte e subsistemas legados. Seria importante o fabricante incluir uma lista de possíveis perigos associados com o Sistema Eletromédico Programável. A lista das possíveis causas para perigos pode conter, por exemplo, falta de segurança de dados, interações indesejadas com outros programas e vírus, etc.

A conformidade para este ensaio é a verificação dos arquivos de Gerenciamento de Risco.

\subsubsection{Controle de Risco}

Para este item os fabricantes devem ter procedimentos e ferramentas adequadas para implementar o controle de risco. As três principais maneiras de controle de risco descrito pela NBR ISO 14971:2009 é a segurança inerente ao projeto, medidas de proteção no próprio projeto e informações para segurança.

Os procedimentos e as ferramentas devem ser apropriados para garantir que cada meio de controle de risco reduza de maneira satisfatória os riscos associados. 


\section{- Comentários:}

A Norma NBR ISO 14971:2009 prescreve que uma das maneiras de controle de risco é aplicar medidas de proteção, mas a Norma não prescreve quais são essas medidas. Deste modo, cabe ao fabricante utilizar todo o seu conhecimento sobre o equipamento, aplicar os meios de proteção da maneira mais sensata possível e descrevê-los nos arquivos de Gerenciamento de Risco.

Já os laboratórios devem avaliar o equipamento, verificar e analisar os riscos levantados pelo fabricante descritos no arquivo de Gerenciamento de Risco, utilizar toda a experiência do ensaiador para verificar se há outros riscos que não foram explorados, em seguida verificar e analisar as medidas de proteção tomadas. Após este trabalho, relatar para o cliente se são ou não satisfatórias as medidas de proteção.

Conclui-se que é de fundamental importância tanto os fabricantes quanto os laboratórios terem pessoas altamente treinadas em sua equipe.

\subsubsection{Verificação.}

A verificação é prescrita para todas as funções que implementam segurança básica, desempenho essencial ou providências de controle de risco. Verificação é a confirmação através de exame e fornecimento de evidência objetiva do atendimento dos requisitos. Compreende também o processo de exame do resultado de uma dada atividade para determinar conformidade.

Um plano de verificação deve incluir as seguintes características:

- A seleção e documentação de estratégias, atividades e técnicas de verificação e o nível apropriado de independência do pessoal que realiza a verificação;

- A seleção e utilização de ferramentas para a verificação;

- Critério de cobertura para a verificação; 


\section{- Comentários:}

Assim como os demais ensaios da seção 14 da Norma ABNT NBR IEC 60601-1:2010, este ensaio é muito genérico, pois prescreve que o fabricante deve fazer, mas não diz como, ou seja, deixa em aberto a elaboração da solução.

\subsubsection{Validação do Sistema Eletromédico Programável.}

Após o equipamento ser desenvolvido, a fase final para o Sistema Eletromédico Programável é a sua validação. A validação é importante, pois garante através de ensaios e análises que o produto correto foi construído.

A Norma 60601-1:2010 especifica que a validação deve ser realizada por pessoas independentes da equipe de projeto, para que não ocorra conflitos de interesses. No arquivo de Gerenciamento de Risco devem estar documentadas as relações entre os membros da equipe de validação e os membros da equipe de projeto, assim como os métodos e resultados de todo o processo de validação.

\subsection{ENSAIOS DA NORMA COLATERAL IEC 60601-1-6:2006.}

Conforme prescrito pelo FDIS de 2011 da Norma 60601-2-24, todos as bombas de infusão e controladores devem ser ensaiados pela IEC 60601-1-6:2006 que contêm prescrições de Usabilidade. O item 12.2 da Norma 60601-1:2010 contém prescrições para a verificação do processo de engenharia de usabilidade enviado pelo fabricante, e há uma citação para o ensaiador ver a Norma IEC 606011-6.

Usabilidade conforme definido pela IEC 60601-1-6:2006 ${ }^{[31]}$ é uma medida da efetividade, eficiência e satisfação com o qual o operador alcança objetivos 
especificados em ambientes particulares de sua utilização. Para verificar se 0 equipamento demonstra uma adequada usabilidade, algumas especificações de fatores que influenciam são necessárias, por exemplo, operador, objetivos, condições e ambientes em que o operador interage com o equipamento. Toda esta série de itens deve ser estudada e validada no equipamento e indicada nos arquivos de engenharia de usabilidade. Conforme indicado pela própria Norma Colateral, o arquivo de engenharia de usabilidade pode fazer parte do arquivo de Gerenciamento de Risco.

\subsubsection{Segurança para o paciente, operador e outras pessoas.}

Um processo de engenharia de usabilidade deve ser estabelecido para prover ao paciente, operador e outras pessoas a usabilidade da interface operador equipamento.

$\mathrm{Na}$ Norma são citados alguns perigos ao paciente, por exemplo: interrupção involuntária da entrega da terapia, interpretação dos valores apresentados seguido de um tratamento inadequado, apresentação de dados confusos que contribuem para a fadiga mental, resultando em maior erro de utilização.

São citados também os seguintes perigos ao operador: projeto ergonômico pobre, levando a lesões músculo-esqueléticas; movimentos repetitivos, resultando lesões no nervo / tendão; o contraste do display ruim, resultando em fadiga ocular; barulho que emana do equipamento, resultando em deficiência auditiva.

A conformidade para este item é verificada através da realização de ensaios dos demais ensaios da Norma Geral e Normas Particulares. 


\subsubsection{Especificação de aplicação do equipamento}

O fabricante deve especificar a aplicação do equipamento no arquivo de engenharia de usabilidade.

A especificação deve incluir: propósito médico (por exemplo, condições ou doenças a serem monitoradas, tratadas ou diagnosticadas); população de paciente (por exemplo, idade, peso região do corpo a ser aplicado); aplicação (por exemplo, ambiente, frequência de uso, local).

Um resumo da aplicação do equipamento deve ser incluído nos documentos acompanhantes.

A conformidade para este item é verificada através da inspeção do arquivo de engenharia de usabilidade e dos demais documentos acompanhantes.

\section{- Resultado do ensaio de especificação do equipamento}

Nos arquivos de Gerenciamento de Risco, não foram encontradas informações sobre usabilidade, porém nos documentos acompanhantes do equipamento (Manual de Utilização) foi encontrada uma informação sobre a especificação de utilização do equipamento.

Conclui-se que o fabricante atendeu uma parte da especificação deste item, ou seja, descreveu um resumo da aplicação do equipamento no Manual de utilização, mas faltou o desenvolvimento do arquivo de engenharia de usabilidade.

\subsubsection{Análise de Risco}

Uma análise de risco focada em usabilidade deve estar em conformidade com a cláusula 4 da Norma NBR ISO 14971:2009. Na análise de risco devem estar especificadas as seguintes condições: especificação da aplicação; perfil do operador; erros previsíveis de uso; contexto para a utilização; informação sobre os perigos existentes para o operador do equipamento, interfaces para equipamentos de qualquer tipo similar, se disponível. 
Para controle de risco relacionado à usabilidade, o fabricante deve decidir qual informação é necessária para a segurança, por exemplo, avisos, marcação ou limitação de uso descrito nos documentos acompanhantes.

Os resultados desta análise de risco ou uma referência de um documento para com os resultados da análise deve ser informado no arquivo de engenharia de usabilidade.

\section{- Resultado do ensaio de Análise de Risco}

$O$ equipamento não possui arquivo de engenharia de usabilidade. $O$ fabricante declarou que está em processo de melhoria e atualização para a finalização dos documentos.

\subsubsection{Especificação de Usabilidade}

Como parte do processo de engenharia de usabilidade, o fabricante deve desenvolver a especificação de usabilidade. A especificação de usabilidade deve ser baseada em: especificação da aplicação, perigos relacionados ao uso do equipamento, erro de uso previsível associado ao equipamento. A especificação de usabilidade deve descrever no mínimo: ações do operador relacionadas à função operacional primária; interface operador - equipamento e requisitos para determinar se as funções operacionais primárias são facilmente reconhecíveis pelo operador.

A função operacional primária é uma função diretamente relacionada à segurança do equipamento em utilização normal ou uma função frequentemente utilizada. Dois exemplos de função operacional primária que está diretamente relacionada à segurança são o ajuste de parâmetro de infusão de uma bomba de infusão e a inativação de um alarme (temporariamente ou indefinidamente).

A conformidade para este item é verificada através da inspeção do arquivo de engenharia de usabilidade. 
- Resultado do ensaio de especificação de usabilidade

O equipamento não possui arquivo de engenharia de usabilidade. $O$ fabricante declarou que está em processo de melhoria e atualização para a finalização dos documentos.

\subsubsection{Verificação da Usabilidade}

Como parte do processo de verificação do projeto do equipamento, o fabricante deve verificar o projeto da interface operador - equipamento de acordo com a especificação de usabilidade. Os resultados da verificação devem ser registrados no arquivo de engenharia de usabilidade.

A conformidade para este item é verificada através da inspeção do arquivo de engenharia de usabilidade.

\section{- Resultado do ensaio de especificação de usabilidade}

O equipamento não possui arquivo de engenharia de usabilidade. $O$ fabricante declarou que está em processo de melhoria e atualização para a finalização dos documentos.

\section{- Comentários}

A verificação da usabilidade deve ser feita através de um processo de observação e coleta de dados vindas do operador final do equipamento. Como a Norma IEC 60601-1-6:2006 não descreve como deve ser feito todo o processo, uma sugestão seria o fabricante proporcionar o equipamento ou um protótipo, simular um ambiente de utilização real ou mesmo no próprio ambiente onde o equipamento será utilizado. Seria interessante para este item da Norma, utilizar um grupo de pessoas com diferentes instruções para testar o produto. Por exemplo, enfermeiros, técnicos de enfermagem e auxiliares de enfermagem. Outro fato interessante é testar o produto em diferentes hospitais ou clínicas e coletar informações e opiniões de todos. O mesmo poderia acontecer na própria fábrica, simular um ambiente de uso e 
convocar pessoas que não estavam envolvidas com o projeto do produto para testalo.

\subsubsection{Plano de Validação de Usabilidade}

Todo fabricante deve desenvolver um plano de validação de usabilidade. Neste plano deve ser especificado qualquer método usado para a validação da usabilidade das funções operacionais primárias; os critérios para determinar a validação de usabilidade.

O método de validação de usabilidade pode ser quantitativo ou qualitativo, pode ser realizado em um laboratório, em uma simulação de ambiente de uso ou no próprio ambiente de uso.

O plano de validação deve apresentar:

- Os piores cenários de uso derivados de: especificação de aplicação; previsíveis erros de uso e os resultados da análise de risco.

- Cenários de uso representando situações de aplicação freqüentes identificados na usabilidade.

O plano de validação de usabilidade deve estar presente no arquivo de engenharia de usabilidade.

A conformidade para este item é verificada através da inspeção do arquivo de engenharia de usabilidade.

\section{- Resultado do ensaio de plano de validação de usabilidade}

O equipamento não possui arquivo de engenharia de usabilidade. $O$ fabricante declarou que está em processo de melhoria e atualização para a finalização dos documentos.

\section{- Comentários}

Assim como acontece com os procedimentos descritos pelos laboratórios de Ensaios que precisam ser validados, os fabricantes precisam ter um plano para validar tudo $\circ$ que foi descrito para 0 arquivo de engenharia de usabilidade. A 
validação nada mais é do que o fabricante assegurar que o produto certo foi construído. Verificar se o equipamento construído, por exemplo, uma bomba de infusão realmente funciona para o propósito ao qual ela é destinada, ou seja, infundir medicamento ao paciente com exatidão, ter uma boa interface operador equipamento e ter documentos acompanhantes claros e objetivos. Muitas vezes, documentos acompanhantes com muitas informações atrapalham ou tiram o foco principal do usuário. O mesmo pode acontecer com displays e botões, pois muitas luzes e muitas informações, diversos botões para a mesma função ou sequências longas para acessar uma determinada função, pode atrapalhar ou mesmo frustrar o operador. Por todos esses motivos é importante fazer uma validação com o usuário final.

\subsection{ENSAIO DE EXATIDÃO DE DADOS DA NORMA IEC 60601-2-24}

Todos aqueles equipamentos eletromédicos que possuem uma Norma Particular são ensaiados neste item através de suas Normas Particulares, pois complementa os ensaios da Norma Geral.

\section{- Procedimento de ensaio}

O ensaio inicia-se com a montagem do arranjo (conforme descrito nas figuras da própria Norma) e a preparação do equipamento eletromédico. Para os ensaios, aos quais são necessários utilizar contrapressões de $+100 \mathrm{mmHg}$ e $-100 \mathrm{mmHg}$, é utilizada uma caixa de pressão que foi construída pela DEC-LEB/EPUSP. Para a geração dessas contrapressões são utilizados compressores de ar comprimido e bomba de vácuo. O controle dos valores das contrapressões é efetuado por um vacuômetro calibrado (quando utilizada pressão negativa) ou por um manômetro calibrado (quando utilizada pressão positiva). No interior da caixa é colocada a balança analítica com exatidão de cinco casas decimais em gramas. Acima do prato da balança encontra-se um becker de plástico, onde o líquido que está sendo infundido pelo equipamento sob ensaio é depositado. A balança analítica possui uma interface RS 232 utilizada para fazer uma conexão com um computador que 
coleta os dados de infusão do equipamento sob ensaio. As informações coletadas pela balança são armazenadas por um programa instalado no computador.

$O$ arranjo de ensaio deve ser montado em um local apropriado, livre de qualquer trepidação e longe de qualquer fonte que possa afetar os resultados. A agulha do equipo deve ser mergulhada em uma quantidade pequena de líquido no interior do becker sem tocar nas paredes e nem no fundo do recipiente.

O equipamento é montado com um equipo novo preenchido com água com solução salina a uma densidade de $0,998 \mathrm{~g} / \mathrm{ml}$. Liga-se o computador com o programa que coleta os dados da infusão e, em seguida é necessário observar se os dados lidos pela balança correspondem ao mostrado no programa. Antes de colocar o equipamento para infundir é preciso deixar a balança estabilizar e verificar através do manômetro ou vacuômetro (quando utilizados) a pressão no interior da caixa. Após a estabilização, inicia-se a aquisição dos dados e depois de alguns minutos inicia-se a infusão do líquido.

Após a coleta de dados, é realizado um tratamento dos dados para montagem dos gráficos solicitados no item 50 da Norma IEC 60601-2-24. Após a realização desse tratamento de dados são gerados os gráficos de partida e curvas de trombeta.

\section{- Resultados do Ensaio de Exatidão de Dados}

Para a realização deste ensaio, foi montado o arranjo como requerido pela Norma IEC 60601-2-24 e ensaiada uma bomba de infusão volumétrica nas vazões de $1 \mathrm{ml} / \mathrm{h}$ e $25 \mathrm{ml} / \mathrm{h}$. Para o processamento dos dados, há no laboratório dois procedimentos diferentes, o primeiro utilizando o programa Excel, com as equações 1 a 5 dispostas nas células, e um outro, utilizando o programa Labview. Os resultados dos gráficos a seguir apresentados foram obtidos através da utilização do Excel. 


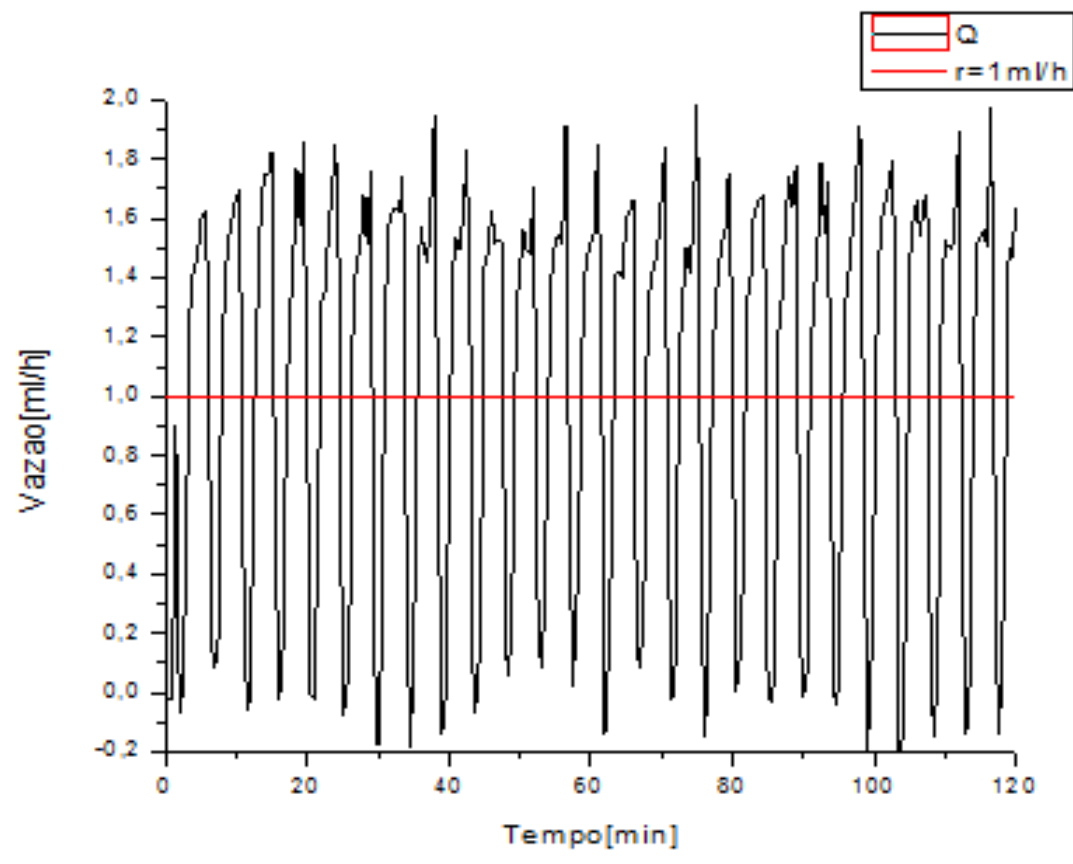

Figura 4.7 - Gráfico de Partida 1ml/h, 2 horas de ensaio.

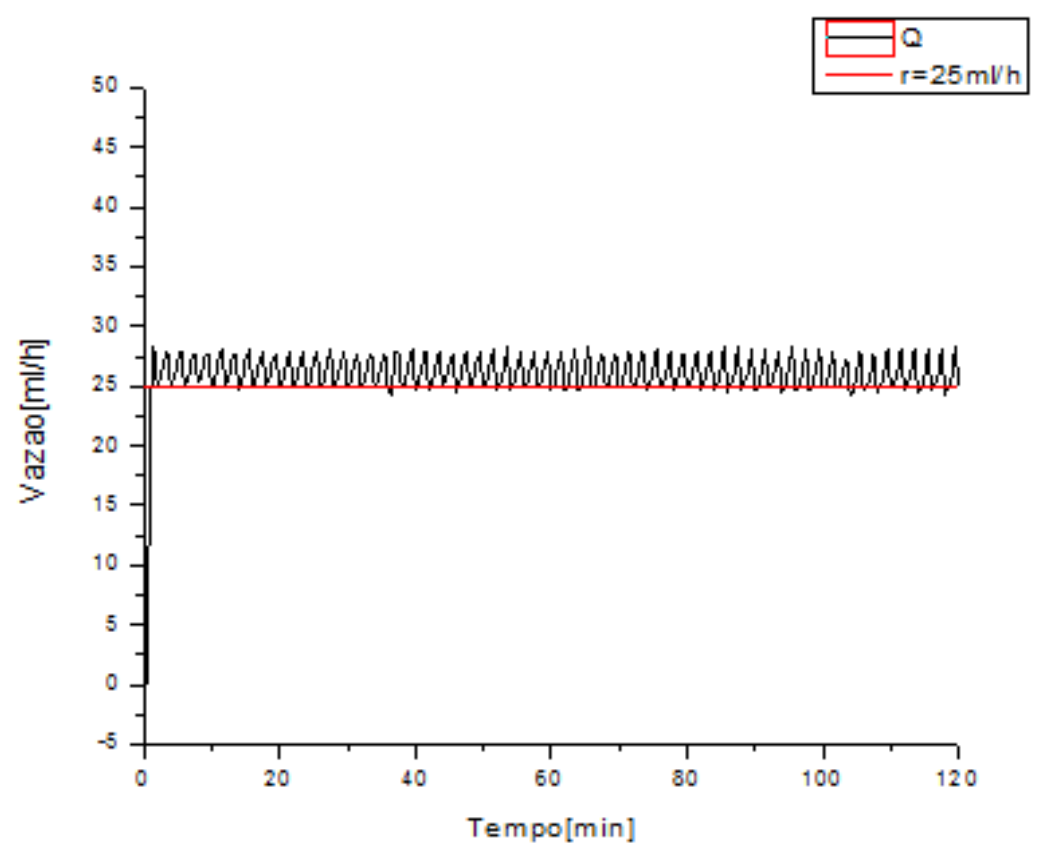

Figura 4.8 - Gráfico de Partida 25ml/h, 2 horas de ensaio sem pressão adicional.

Os gráficos de partida são importantes, pois apresentam uma visão geral do comportamento do equipamento no tempo de ensaio. $\mathrm{Na}$ análise destes gráficos, sem reproduzir as curvas de trombeta, ao olhar para a Figura 4.7, pode-se dizer que o equipamento possui um erro máximo e mínimo muito grande. Também é possível observar pequenos refluxos que podem ocorrer em vazões muito baixas, por 
exemplo, abaixo de $1 \mathrm{ml} / \mathrm{h}$ devido a instabilidade do sistema mecânico. Para a Figura de 4.8 a situação é diferente e pode-se observar que o equipamento possui um erro máximo bem maior que o erro mínimo.

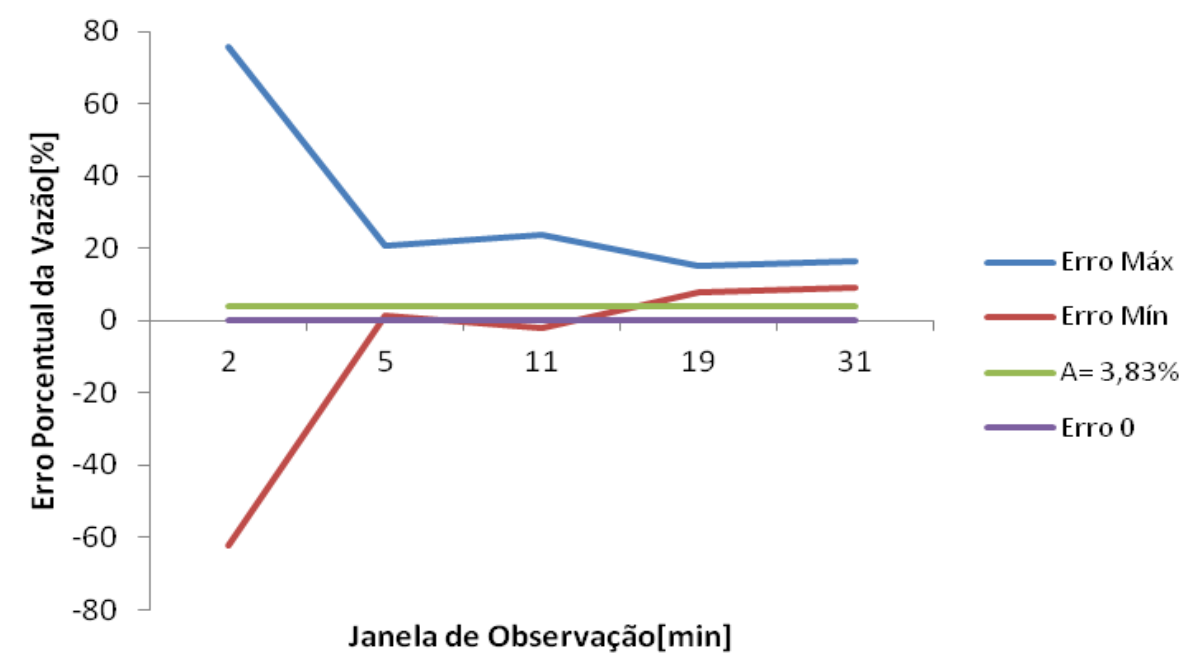

Figura 4.9 - Curva de Trombeta, $2^{\mathrm{a}}$ hora de ensaio, $1 \mathrm{ml} / \mathrm{h}$.

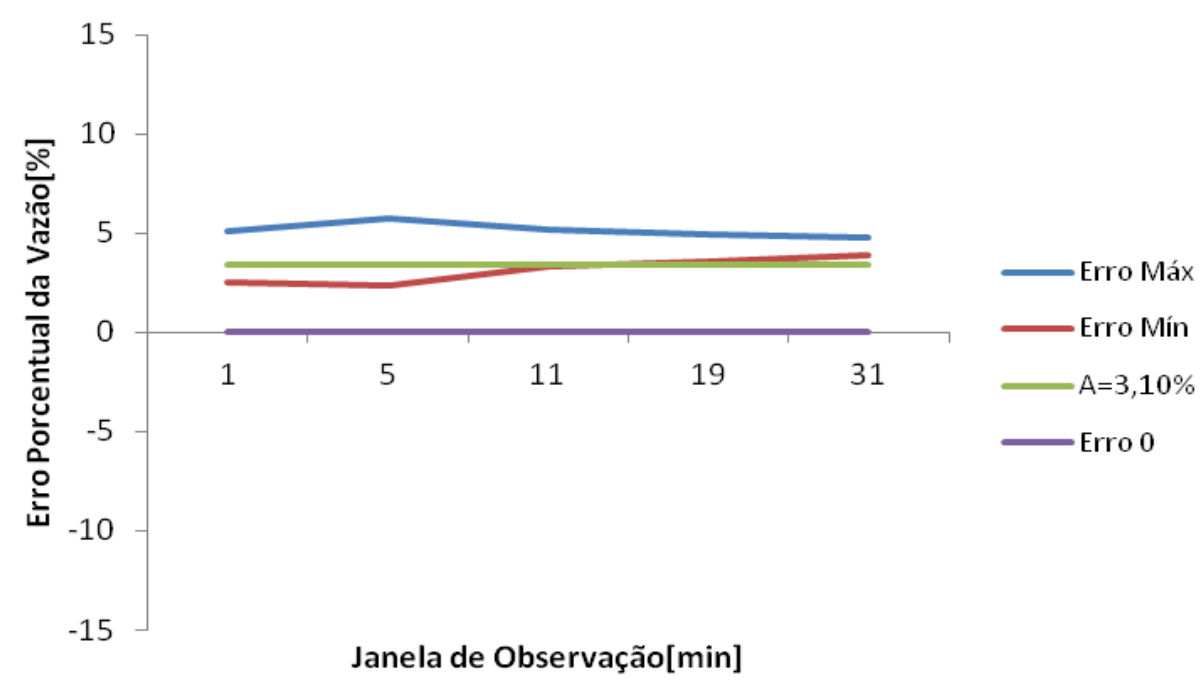

Figura 4.10 - Curva de Trombeta, $2^{\mathrm{a}}$ hora de ensaio, $25 \mathrm{ml} / \mathrm{h}$.

A curva de trombeta ilustra as flutuações na exatidão da vazão média nas janelas de observações específicas. As flutuações da vazão podem ser causadas por alguns fatores, tais como: densidade do líquido, temperatura e pressão ambiente, pressão positiva ou negativa, deformação do equipo, posição do recipiente, etc. 
O fabricante declarou nos documentos acompanhantes uma exatidão de $\pm 5 \%$ da vazão. Ao observar as Figura 4.9 e 4.10 é possível verificar que a exatidão da vazão do equipamento, indicado pela letra "A" está dentro dos valores especificados pelo fabricante.

\subsection{RESULTADO ESPERADO APÓS A AUDITORIA DO INMETRO}

Todo ano é realizada nos laboratórios da RBLE uma auditoria de manutenção da acreditação. Também são realizados, quando pedido pelos laboratórios, auditorias de extensão quando um laboratório quer aumentar seu escopo de ensaios. Auditoria é um exame cuidadoso e sistemático que o Inmetro faz para averiguar se os laboratórios estão trabalhando de acordo com as especificações contidas na Norma ABNT NBR ISO IEC 17025:2005.

Nas auditorias do Inmetro, na área técnica, um dos itens a ser avaliado é o método de ensaio. Neste item é verificada a reprodutibilidade dos ensaios, a clareza das informações e como são tratadas as incertezas de medições. $O$ auditor avalia os processos de ensaios, verificando se os mesmos reproduzem os ensaios nos equipamentos eletromédicos de forma correta, de acordo com o que é especificado nas Normas da série ABNT NBR IEC 60601/80601.

Após terem sido implantados na DEC-LEB/EPUSP todos os itens desta pesquisa, o último estágio para a finalização da implantação do Gerenciamento de Risco no laboratório é a auditoria do Inmetro. Os auditores avaliam todas as ações adotadas e após a auditoria são relatadas e discutidas as falhas a serem corrigidas, o tempo para o laboratório fazer as melhorias e a concretização do processo de implantação do Gerenciamento de Risco, ou seja, acreditam o laboratório como apto a ensaiar pela nova edição da Norma Geral.

A auditoria ainda não foi realizada na DEC-LEB/EPUSP, mas espera-se que após o desenvolvimento das atividades descritas neste trabalho, o laboratório consiga a extensão de acreditação junto ao Inmetro. Até o presente momento não há uma previsão para a realização da auditoria, pois se leva meses para agendar uma junto ao Inmetro. 


\section{CONCLUSÃO}

Com a finalização deste trabalho, puderam-se obter as seguintes conclusões.

\subsection{CONCLUSÃO SOBRE A NORMA ABNT NBR IEC 60601-1:2010 E ABNT NBR ISO 14971:2009}

Após a finalização deste trabalho, conseguiu-se uma resposta para a seguinte questão individual levantada: Qual a necessidade de uma Norma Técnica para Gerenciamento de Risco e qual a sua finalidade? As seguintes conclusões foram obtidas:

- Há necessidade de gerenciar riscos durante o ciclo de vida do produto.

- O produto final será melhor desenvolvido e mais seguro. Certamente muitos fabricantes necessitarão e deverão melhorar muito seus produtos para atender todos os requisitos.

- Deve ser aplicado a todos os estágios do ciclo de vida do produto, pois problemas podem acontecer em qualquer estágio, ou seja, correções podem ser feitas a todo o momento, mas é importante lembrar que é menos difícil de realizá-las no início do projeto.

- O reconhecimento de órgãos reguladores, por exemplo, o FDA, sobre a necessidade dos fabricantes aplicarem Gerenciamento de Risco em produtos para a saúde.

Um fabricante bem estruturado, com uma boa equipe de pesquisa e projeto pode com estas Normas e demais Normas relacionadas a produtos para a saúde desenvolver um produto seguro. Para isto, o fabricante necessita ter documentação alinhada com requisitos de Gerenciamento de Riscos e os riscos do projeto; ensaios para a verificação e validação do equipamento eletromédico; gerenciar a fabricação, desenvolvendo auditorias internas e ter uma equipe que faça o gerenciamento das 
informações pós-mercado, pois estas informações são importantes para incorporar e, consequentemente, contribuir para a evolução do produto, podendo ser possivelmente aplicada a outros produtos da empresa e até em novos projetos.

O arquivo de Gerenciamento de Risco precisará levar em consideração os riscos associados para cada seção e subseção das novas edições das Normas. Certamente os fabricantes terão um grande trabalho para dispor todas as informações necessárias, caso contrário, muitos ensaios não poderão ser realizados pelos laboratórios de ensaios. Um exemplo deste fato pode ser observado no capítulo 4, nos itens referentes à exatidão de dados e usabilidade.

As Normas exigirão dos fabricantes um bom conhecimento de seus próprios equipamentos eletromédicos, pois os mesmos precisarão analisar e detalhar no arquivo de Gerenciamento de Risco, componentes, softwares, hardwares e partes que influenciam na segurança do produto. Sabe-se que muitos fabricantes terceirizam diferentes partes e peças do equipamento e, certamente tudo isso, poderá tomar certo tempo de empresas que realmente trabalham com seriedade para desenvolver todo o arquivo de Gerenciamento de Risco.

No início, na utilização das novas edições das Normas pelos laboratórios de ensaios, certamente os equipamentos eletromédicos que precisarão ser ensaiados, levarão tempo maior de ensaio, talvez três semanas ou mais devido a toda necessidade de análise da documentação em conjunto com os ensaios. Após aquisição de experiência pelos ensaiadores, o tempo tenderá a diminuir, mas certamente continuará sendo maior do que os prazos atualmente proposto pelos laboratórios de ensaios em seus orçamentos.

\subsection{CONCLUSÃO SOBRE A NORMA IEC 60601-2-24}

Com a análise do FDIS de 2011 da IEC 60601-2-24 percebeu-se que esta Norma foi enriquecida com a adição de requisitos de Normas Colaterais como, por exemplo, a IEC 60601-1-6, 60601-1-8, 60601-1-10 e 60601-1-11. Os demais ensaios que já existiam na edição de 1999 se mantiveram e não sofreram grandes alterações. Fato muito triste, pois alguns ensaios precisavam ser melhorados e 
esperava-se que com a revisão e reformulação das Normas da série IEC 60601 isso acontecesse. Um exemplo que pode ser dado é o ensaio de exatidão de dados. Infelizmente o ensaio é realizado somente na vazão de $1 \mathrm{ml} / \mathrm{h}$ e $5 \mathrm{ml} / \mathrm{h}$ (bomba de seringa) ou $1 \mathrm{ml} / \mathrm{h}$ e $25 \mathrm{ml} / \mathrm{h}$ (bomba de infusão volumétrica). Seria importante que os ensaios fossem estendidos para outras vazões, pois bombas de Infusão de uma forma geral possuem ajustes de vazão que variam de $0,1 \mathrm{ml} / \mathrm{h}$ a $999,99 \mathrm{ml} / \mathrm{h}$. Houve casos no laboratório DEC-LEB/EPUSP de equipamentos enviados por hospitais que compraram bombas de infusão que precisaram ser reensaiadas, pois apresentaram problemas em vazões não especificadas pela Norma Particular. Talvez pudesse ser feito um estudo verificando as principais vazões utilizadas no ambiente hospitalar, e desta forma, alterar as prescrições para o ensaio de exatidão de dados. Existem outras prescrições com problemas semelhantes, ou seja, com a necessidade de melhoria. Esse foi o desapontamento em relação ao FDIS da Norma IEC 60601-224, ou seja, a falta de evolução de alguns ensaios importantes.

O ponto forte foi a adição de prescrições de ensaio de Normas Colaterais, por exemplo, a IEC 60601-1-6. Essa Norma Colateral prescreve ensaios importantes sobre usabilidade, assunto relativamente novo que esclarece os problemas dos antigos ensaios sobre "erros humanos". Muitos problemas ocorriam por falta de informação ou excesso de informação desnecessária, mas em alguns casos ocorriam por falta de avisos, símbolos, etc. Essa Norma Colateral irá melhorar o manual de instruções e outros avisos pertinentes para a utilização.

\subsection{CONCLUSÃO APÓS A PESQUISA FEITA COM OS FABRICANTES DE EQUIPAMENTOS ELETROMÉDICOS}

Com as pesquisas feitas com os fabricantes, pode-se verificar o quanto alguns estão preocupados em proporcionar ao paciente e operador um equipamento cada vez mais seguro. Também foi possível examinar as principais ferramentas utilizadas pelos fabricantes no Gerenciamento de Risco e, desta forma, apresentálas à equipe do laboratório para a concretização dos treinamentos. 
Finalmente, após a pesquisa e análise de arquivos de Gerenciamento de Risco, percebeu-se a preocupação dos fabricantes, mas concluiu-se que algumas arquivos de Gerenciamento de Risco não atendem por completo aos requisitos da Norma ABNT NBR ISO 14971:2009 e da ABNT NBR IEC 60601-1:2010. Os principais motivos verificados foram:

- Desconhecimento ou conhecimento parcial da Norma ABNT NBR ISO 14971:2009 e/ou da ABNT NBR IEC 60601-1:2010.

- Utilização de uma única metodologia, por exemplo, a utilização somente da FMEA para atender aos requisitos da Norma ABNT NBR ISO 14971:2009.

- Utilização de forma errada de algumas metodologias, como por exemplo, a utilização superficial da FMEA.

Desta forma, conclui-se o quão importante é ter bons procedimentos técnicos e uma equipe amplamente qualificada nos laboratórios de ensaios, pois desta forma, pode-se analisar os arquivos de Gerenciamento de Risco de uma forma ampla e com maturidade no assunto, além de auxiliar os fabricantes no enriquecimento desses arquivos e, consequentemente, colaborar com o desenvolvimento de equipamentos eletromédicos mais seguros para o país.

\subsection{CONCLUSÃO FINAL}

O tema Gerenciamento de Risco em laboratórios de ensaios é relativamente novo e, inicialmente, ao analisar os arquivos dos fabricantes surgirão dúvidas que necessitarão ser discutidas e avaliadas por mais de uma pessoa da equipe do laboratório. Existirá também a necessidade da leitura repetitiva de muitos termos definidos empregados nos arquivos de Gerenciamento de Risco.

O processo de implantação do Gerenciamento de Risco na DEC-LEB/EPUSP teve como objetivo a elaboração de procedimentos de ensaios e/ou a atualização de outros para estarem de acordo com os requisitos das Normas ABNT NBR IEC $60601 / 80601$. A validação dos procedimentos utilizando uma bomba de infusão e o treinamento da equipe para a análise dos arquivos de Gerenciamento de Risco também fizeram parte deste processo de implantação. A parte crítica no processo 
de implantação, certamente, foi adquirir o conhecimento e transmiti-lo aos demais membros da equipe da DEC-LEB/EPUSP, pois para assuntos novos, e com certa complexidade, leva-se tempo para que todos possam assimilar as informações e criar uma base de conhecimento. Com certeza, a fase mais difícil do aprendizado já foi ultrapassada, mas ainda resta a aquisição da experiência continuada. 


\section{TRABALHOS FUTUROS}

Os procedimentos serão atualizados novamente, se necessário, após ser realizada a auditoria do INMETRO. Esta nova atualização atenderá as recomendações descritas no relatório de avaliação dos auditores.

Para trabalhos futuros haverá a atualização dos procedimentos de ensaios das demais Normas Particulares da série 60601. Esta nova fase já esta em desenvolvimento através da atualização dos procedimentos das Normas IEC 606012-19:2009, IEC 60601-2-20:2009, IEC 60601-2-21:2009, IEC 60601-2-35:2009 e ABNT NBR IEC 60601-2-50:2010.

A criação de novos cursos de reciclagem também ocorrerá. Estes cursos estão programados para serem realizados semestralmente e o objetivo principal é a troca de experiências entre os participantes sobre a análise dos arquivos de Gerenciamento de Risco de diferenciados equipamentos eletromédicos. 
REFERÊNCIAS BIBLIOGRÁFICAS

[1] ASSOCIAÇÃO BRASILEIRA DE NORMAS TÉCNICAS. NBR IEC 60601-1: Equipamento eletromédico - Parte 1: Requisitos gerais para segurança básica e desempenho essencial. Rio de Janeiro, 2010.

[2] BRASIL. Instituto Nacional de Metrologia. Portaria $\mathrm{n} .-0$ 350, de 06 de setembro de 2010. Requisitos de Avaliação da Conformidade para Equipamentos Elétricos sob Regime da Vigilância Sanitária, Rio de Janeiro, p. 1-22, Setembro de 2010.

[3] BRASIL. Agência Nacional de Vigilância Sanitária do Ministério da Saúde. Resolução RDC ํo 27, de 21 de Junho de 2011. Dispõe sobre os procedimentos para certificação compulsória dos equipamentos sob regime de Vigilância Sanitária, Brasília, p. 1-5, Junho de 2011.

[4] BRASIL. Agência Nacional de Vigilância Sanitária do Ministério da Saúde. Instrução Normativa/Anvisa no03/11, 21 de Junho de 2011.

[5] ASSOCIAÇÃO BRASILEIRA DE NORMAS TÉCNICAS. NBR ISO/IEC 17025: Requisitos Gerais para a Competência de Laboratórios de Ensaio e Calibração. Rio de Janeiro, 2005.

[6]INMETRO, Disponível em: <http://www.inmetro.gov.br/qualidade/certificacao.asp>. Acesso em: 09 Jan. 2012.

[7] ROSA, D.A.O. Elaboração de Manuais de Procedimentos Técnicos e Montagem de Gigas para a Realização de Ensaios em Bombas de Infusão. 2007. Dissertação (Monografia para conclusão do curso de Tecnologia em Saúde) Faculdade de Tecnologia de Sorocaba, Sorocaba, 2007.

[8] ASSOCIAÇÃO BRASILEIRA DE NORMAS TÉCNICAS. NBR IEC 60601-1: Equipamento eletromédico - Parte 1: Prescrições Gerais para segurança, Rio de Janeiro, 1997.

[9] ASSOCIAÇÃO BRASILEIRA DE NORMAS TÉCNICAS. NBR IEC 60601-1-4: Equipamento eletromédico - Parte 1-4: Prescrições gerais para segurança - Norma Colateral - Sistemas eletromédicos programáveis, Rio de Janeiro, 2004.

[10] BRITISH STANDARD INSTITUTION. BSI 6079-1 - Part 1: Guide to the Project Management, England, 2000. 
[11] NAVARRO, S.S. Planejamento de Empreendimentos Imobiliários: Gestão de Risco Orientada a Gestão de Prazo com ênfase na Identificação de Alertas Antecipados. 2007. Dissertação (Mestrado) - Escola Politécnica, Universidade de São Paulo, São Paulo, 2007.

[12] COOPER, D.; GREY, S. Project Risk Management guidelines. New York: John Wiley \&Sons, 2005.

[13] ASSOCIAÇÃO BRASILEIRA DE NORMAS TÉCNICAS. NBR ISO 14971: Aplicação do Gerenciamento de Risco para Dispositivos Médicos. Rio de Janeiro, 2009.

[14] KERZNER, H. Project Managment: a systems approach to planning, scheduling, and controling. USA: John Wiley \& Sons Inc, 2001.

[15] SIMISTER, S. J. Qualitative and Quantitative Risk Management. In: MORRIS, P. W.; PINTO, J. K. The Wiley Guide to project control. New Jersey: John Wiley \& Sons Inc, 2007. p. 97-113.

[16] NORRIS, C.; PERRY, J.; SIMON, P. Project Risk Analysis and Management. A Guide By The Association for Project Management. 85 Oxford Road, High Wycombe, Mach 1992, republished January 2000.

[17] STANDARD AUSTRALIAN AND STANDARD NEW ZEALAND. AS/NZS 4360: Risk Management. Austrália, 2004.

[18] FLORENCE, G.; CALIL, S.J. Gerenciamento de Risco Aplicado ao Desempenho de Equipamentos Médicos. SBM: Sociedade Brasileira de Metrologia, Recife, p. 1-4, Setembro 2003.

[19] TOLEDO, J. C.; AMARAL, D.C. FMEA - Análise do Tipo e Efeito de Falha. São Carlos: GEPEQ - Grupo de Estudo e Pesquisa em Qualidade, UFSCar, 12 p. Apostila. Disponível em: <http://www.guiametal.com.br/uploads/pdf/o-que-efmea.pdf>. Acesso em: 26 maio 2011.

[20] RIBEIRO, K. S. FMEA - Análise dos Modos de Falha e Efeitos Metodologia de Qualidade em Projetos de Sistemas de Informação. 2009. Dissertação (Monografia para a conclusão do curso de Tecnologia em Informática) - Faculdade de Tecnologia Zona Leste, São Paulo, 2009. 
[21] LAURENTI, R. Sistematização de problemas e práticas da análise de falhas potenciais no processo de desenvolvimento de produto. 2010. Dissertação (Mestrado) - Escola Politécnica, Universidade de São Paulo, São Paulo, 2010.

[22] FERREIRA, A. G. G. FMEA em Gerenciamento de Riscos em Projetos. Disponível em: <http://bessegato.sites.uol.com.br/Management/fmea.pdf>. Acesso em: 04 Jun. 2010.

[23] STAMATIS, D. H. Failure Mode and Effect Analysis: FMEA from Theory to Execution. ASQ Quality Press, 2003. 445p.

[24] FIDALGO, J. E. L. R. Maximização de Receita de Concessionária de Transmissão de Energia Elétrica através da Otimização da Manutenção. 2007. Dissertação (Mestrado) - Escola Politécnica, Universidade de São Paulo, São Paulo, 2007.

[25] PASCON, P. E. O Estudo de Perigo e Operabilidade (HAZOP). Disponível em: $<$ http://www.processos.eng.br/Portugues/PDFs/estudo_de_perigo.pdf>. Acesso em: 20 Jun. 2011.

[26] NASA FTA, Fault Tree Handbook with Aerospace Applications, Prepared for NASA Office of Safety and Mission Assurance NASA Headquarters Washington, DC 20546, August, 2002.

[27] KUWABARA, C. C. T. Gerenciamento de Risco em Tecnovigilância: Aplicação dos Conceitos Seis Sigma e Técnica Delphi para o Desenvolvimento e Instrumento de Avaliação de Material Médico Hospitalar. 2009. Tese (Doutorado) Escola de Enfermagem de Ribeirão Preto da Universidade de São Paulo, Ribeirão Preto, 2009.

[28] INTERNATIONAL ELECTROTECHNICAL COMMISSION. IEC 60601-2-24: Medical Electrical Equipment - Part 2-24: Particular Requirements for basic safety and essencial performance of infusion pumps and controllers. Genebra, 2011.

[29] ASSOCIAÇÃO BRASILEIRA DE NORMAS TÉCNICAS. NBR IEC 60601-2-24: Equipamento eletromédico - Parte 2-24: Prescrições particulares para segurança Norma Particular - Bombas e Controladores de Infusão. Rio de Janeiro, 1999. 
[30] CAMARGO, B.R. Adequação da seção Técnica de Ensaio em Equipamentos Eletromédicos para a realização dos ensaios da terceira edição da Norma Geral IEC 60601-1:2005. 2008. Dissertação (Monografia para conclusão do curso de Tecnologia em Saúde) - Faculdade de Tecnologia de Sorocaba, Sorocaba, 2008.

[31] ASSOCIAÇÃO BRASILEIRA DE NORMAS TÉCNICAS. NBR IEC 60601-1-6: Equipamento eletromédico - Parte 1-6: Requisitos gerais para a segurança básica e desempenho essencial - Norma Colateral: Usabilidade. Rio de Janeiro, 2011. 